\title{
REGULATING SCIENTIFIC RESEARCH: INTELLECTUAL PROPERTY RIGHTS AND THE NORMS OF SCIENCE
}

Among legal scholars, a debate is currently raging about the proper scope of intellectual property rights in non-commercial-or "basic"-scientific research. The debate focuses on basic research in molecular biology, the foundational science of the large and dynamic biotechnology industry.

- Associate Professor, University of San Diego Law School. I thank Larry Alexander, Stuart Benjamin, Julie Cohen, John Drobak, Rebecca Eisenberg, Susan Freiwald, Pauline Kim, Mark Lemley, Larry Lessig, Charles McManis, Stephen Munzer, Frank Partnoy, Michael Rappaport, Carol Steiker, and Chris Wonnell for helpful comments. I presented versions of this Article at Harvard University's Program on Ethics and the Professions, the University of San Diego, the Washington University School of Law, St. Louis, and the University of California at Los Angeles School of Law.

I See, eg., Michael Davis, The Patenting of Products of Nature, 21 RUTGERs COMPUTER \& TECH. L.J. 293 (1995); Rebecca S. Eisenberg, Intellectual Property at the Public-Private Divide: The Case of Large-Scale cDNA Sequencing, 3 U. CH. L. SCH. ROUNDTABLE 557 (1996); Rebecca S. Eisenberg \& Robert P. Merges, Opinion Letter as to the Patentability of Certain Inventions Associated with the Identification of Partial cDNA Sequences, 23 AIPLA Q.J. 1 (1995); Matthew Erramouspe, Staking Patent Claims on the Human Blueprint: Rewards and Rent-Dissipating Races, 43 UCLA L. REV. 961, 962-65 (1996); Michael A. Heller \& Rebecca S. Eisenberg, Can Patents Deter Innovation? The Anticommons in Biomedical Research, 280 SCIENCE 698 (1998); Kate H. Murashige, Genome Research and Traditional Intellectual Property Protection-A Bad Fit, 7 RISK: HEALTH SAFETY \& ENV'T 231 (1996); Diana Sheiness, Patenting Gene Sequences, 78 J. PAT. \& TRADEMARK OFF. SOC'Y 121 (1996); G. Kenneth Smith \& Denise M. Kettelberger, Patents and the Human Genome Project, 22 AIPLA Q.J. 27 (1994); Stephen A. Bent \& Paul M. Booth, Genomics Race Raises Ownership Boundary Issue, NAT'L L.J., Jan. 26, 1998, at C3. See also infra note 182 (discussing percentage of university licensing revenue that derives from biotechnology patents).

The definition of basic research merits a brief discussion. Basic research has generally been defined as research that focuses on the formulation of conceptual schemes and their development and testing. See BERNARD BARBER, SCIENCE AND THE SOCIAL ORDER 95 (1953). Because basic research is relatively theoretical in nature, a significant period of time may elapse before basic research has practical consequences. See id. at 98-99. Notably, research may be basic even when it suggests a variety of practical uses. This is because the time period that elapses before the practical uses can be realized is often quite significant. For example, as Samuel Oddi has pointed out, the discovery that certain compositions of matter exhibit superconductive qualities at temperatures well above absolute zero immediately suggested practical applications in the electric power and computer industries. However, because the technology necessary for realization of the practical possibilities was far from obvious, the discovery could still be considered basic. See A. Samuel Oddi, An Uneasier Case for Copyright than for Patent Protection of Computer Programs, 72 NEB. L. REv. 351, 423-24 (1993). Similarly, in the context of biotechnology, most basic research is undertaken with the practical goal of preventing or ameliorating disease in mind. However, the path from the basic research to a particular therapy may be quite circuitous. See Bruce Smith \& Claude Barfield, Contributions of Research and Technical Advance to the 
The issue of intellectual property rights in scientific research ${ }^{2}$ forces scholars to consider not only various competing theories of intellectual property, but also the social norms that have traditionally governed claims of ownership in basic science.

It is fortunate, therefore, that the debate over property rights in science coincides with another notable phenomenon in recent legal scholarship: the veritable explosion of writing on how positive law and social norms operate to shape behavior. ${ }^{3}$ Indeed, the law-and-norms literature is quite rich. Scholars have developed theories of how law and norms can operate synergistically, antagonistically, or independently. ${ }^{4}$ They have applied these theories to a variety of highly disparate contexts that span the regimes of both public and private law-smoking, ${ }^{5}$ the diamond industry, ${ }^{6}$ race and sex

Economy, in TECHNOLOGY, R \& D, AND THE ECONOMY 1 (Bruce Smith \& Claude Barfield eds., 1996) (noting that the path from basic science to commercial product is not linear but rather full of "leaps ahead, feedback loops, and sudden and unexpected lacunae").

2 Unless otherwise indicated, I use the terms "scientific research" and "research" to refer to basic scientific research.

3 In the past two years, there have been a number of symposia devoted to the subject. See, e.g., Symposium, Law, Economics, and Norms, 144 U. PA. L. REV. 1643 (1996); Symposium, Law and Society \& Law and Economics, 1997 WIS. L. REV. 375; Symposium, Normative Failure Theory of Law, 82 CORNELl L. REv. 947 (1997); Symposium, Social Norms, Social Meaning, and the Economic Analysis of Law, 27 J. LEGAL STUD. 537 (1998). Numerous scholars have also devoted themselves to the subject. See, e.g., Lisa Bemstein, Opting Out of the Legal System: Extralegal Contractual Relations in the Diamond Industry, 21 J. LEGAL STUD. 115 (1992); Lawrence Lessig, The Regulation of Social Meaning, 62 U. CHI. L. REV. 943 (1995); Richard H. McAdams, The Origin, Development, and Regulation of Norms, 96 MICH. L. REV. 338 (1997); Eric A. Posner, The Regulation of Groups: The Influence of Legal and Nonlegal Sanctions on Collective Action, 63 U. Cin. L. REV. 133 (1996); Cass Sunstein, Social Norms and Social Roles, 96 CoLUM. L. REv. 903 (1996). As is clear from the dates of these publications, this type of legal scholarship has burgeoned since the publication of Robert Ellickson's influential studies of the norms that govern dispute resolution between farmers and ranchers in Shasta County, Califomia. See ROBERT C. ElliCKSON, ORDER WITHOUT LAW: HOW NEIGHBORS SETTLE DISPUTES (1991); Robert Ellickson, Of Coase and Cattle: Dispute Resolution Among Neighbors in Shasta County, 38 STAN. L. REV. 623 (1986). Because many of the scholars who use law-and-norms analysis are or have been affiliated with the University of Chicago, some have dubbed these scholars the "New Chicago School." See, e.g., Robert C. Ellickson, Law and Economics Discovers Social Norms, 27 J. LEGAL STUD. 537, 538 (1998).

The investigation of cooperative norms is also an important part of "institutional economics," a branch of economic theory on which some legal scholars have focused. See Robert Merges, Contracting into Liability Rules: Intellectual Property Rights and Collective Rights Organizations, 84 CAL. L. REV. 1293 (1996) (discussing, in light of the insights of institutional economics, the formation of private institutions that facilitate intellectual property rights exchange). See also Edward Rubin, The New Legal Process, the Synthesis of Discourse, and the Microanalysis of Institutions, 109 HARV. L. REV. 1393, 1413 (1996) (noting that central contention of institutional economics is that "most economic actors are not isolated individuals engaged in dyadic exchanges, but rather members of complex organizations whose motivations, behaviors, and knowledge are highly affected by their institutional settings"). I dis* cuss the relationship between law-and-norms theory and institutional economics infra note 26.

${ }^{4}$ See generally infra Part I.

5 See Lessig, supra note 3, at 1025-34; Cass R. Sunstein, On the Expressive Function of Law, 144 U. PA. L. REV. 2021, 2035 (1996).

6 See Bemstein, supra note 3. 
discrimination, ${ }^{7}$ the products liability regime in Japan, ${ }^{8}$ the common law, ${ }^{9}$ voting, ${ }^{10}$ and the Internet. ${ }^{11}$

Interestingly, however, scholars have not developed a comprehensive analysis of how law-and-norms theory applies to basic scientific research. ${ }^{12}$ The inattention to scientific research is particularly striking in light of lawand-norms scholars' emphasis on the role of law in facilitating desirable norms and subverting undesirable ones. ${ }^{13}$ This emphasis could be particularly fruitful in the context of scientific research, where changes in intellectual property law have, over the last two decades, undermined allegedly undesirable scientific research norms that emphasize the public domain over property rights. ${ }^{14}$

In this Article, I employ law-and-norms theory to argue that legal change has been insufficiently sensitive to the contexts in which the central instrumental goals of intellectual property-success in stimulating the creation, disclosure, and development of inventive or creative works ${ }^{15}$ - would

7 See Richard H. McAdams, Cooperation and Conflict: The Economics of Group Status Competition and Race Discrimination, 108 HARV. L. REv. 1003, 1064-71, 1083 (1995).

8 See J. Mark Ramseyer, Products Liability Through Private Ordering: Notes on a Japanese Experiment, 144 U. PA. L. REV. 1823 (1996).

9 See Robert Cooter, Decentralized Law for a Complex Economy: The Structural Approach to Adjudicating the New Law Merchant, 144 U. PA. L. REV. 1643 (1996).

10 See Richard Hasen, Voting Without Law, 144 U. PA. L. REV. 2135 (1996).

11 See, e.g., David R. Johnson \& David G. Post, And How Shall the Net Be Governed?: A Meditation on the Relative Virtues of Decentralized, Emergent Law, in COORDINATING THE INTERNET 62 (Brian Kahin \& James Keller eds., 1997).

12 Some intellectual property scholars, notably Rebecca Eisenberg and Robert Merges, have written thoughtful articles examining the relationship between patent law doctrine and the norms of basic science. See, e.g., Rebecca Eisenberg, Proprietary Rights and the Norms of Science in Biotechnology Research, 97 YALE L.J. 177 (1987); Robert Merges, Property Rights and the Commons: The Case of Scientific Research, 13 SOC. PHIL. \& POL. 145 (1996). See also Heller \& Eisenberg, supra note 1 (arguing that norms favoring the routine cross-licensing of intellectual property are unlikely to emerge in biotechnology). These analyses do not, however, discuss in any detail the current state of scientific research norms or focus on the extent to which legal efforts to change scientific norms have achieved (or failed to achieve) their desired goals. They also do not discuss how regulation of norms could be used to further these goals.

${ }^{13}$ See infra notes $51-59$ and accompanying text.

14 See discussion infra Part II.C.

15 Each of these market-focused goals (creation, disclosure, development) underlies the intellectual property grant. However, as discussed in detail below, the relative importance of the various goals is hotly disputed. See generally infra Part III. Notably, whether one is discussing patent law or copyright law, the market-focused analysis is applicable. However, because scientific research typically produces works that are protected by patent law, this Article will emphasize patent law. A caveat on the scope of this Article should be noted at the outset. Although I use an efficiency-based analysis, I do not mean to suggest that such analysis capture the full significance of either intellectual property rights or scientific research norms. To the contrary, as various scholars of intellectual property have pointed out, such rights can be justified not simply on efficiency grounds but also on the basis of values unrelated to efficiency, such as natural rights, labor theory, and personhood. See discussion in note 215 infra. In addition, intellectual property rights (like property rights generally) raise questions regarding justice and equality. See, e.g., Stephen Munzer, The Special Case of Property Rights in Umbilical Cord Blood for 
be maximized not through stronger intellectual property rights, but through norms that militate against the securing of such rights. Given the presence of contexts in which "communality" is more beneficial than property rights, it is fortunate that the changes in intellectual property law have not been completely successful in bringing about a concomitant change in the norms that guide scientific research. Indeed, those scientific research norms that have been most resistant to change are more likely to achieve creation, disclosure, and development than full-blown intellectual property rights. ${ }^{13}$ This is not to say that these norms should, or can, be left unaffected by law. However, due to the relative imprecision of law, the difficulty it often has in dealing with rapid technological change, and the poor access that legal actors generally have to relevant technological information, formulating laws that reinforce and reflect efficient norms may be a better way of achieving creation, disclosure, and development than the alternative of strictly legal change. Drawing on the insights of the law-and-norms literature, I identify a variety of efficient scientific research norms and offer suggestions regarding how law could operate synergistically with these efficient norms.

My analysis divides into four parts. Part I provides an introduction to law-and-norms theory. Part II then uses law-and-norms theory as a lens through which to analyze traditional norms of scientific research as well as legal changes that have replaced research norms with property law. Part III critiques the economic rationale behind these changes by providing an economic justification for preserving a reasonably robust public domain in the field of biotechnology research. Part IV provides an economic model of the costs that need to be balanced in constructing an efficient public domain; it then builds upon the analysis of Parts II and III by describing how those research norms that have persisted in the face of hostile legal changes could be used to preserve this public domain. Part IV concludes by suggesting methods by which law could reinforce and reflect these efficient norms.

Transplantation, 51 RUTGERS L. REV. 493, 498 (1999). Similarly, norms of basic scientific research promote goals and values that cannot be captured by the market. Like norms of academic freedom generally, basic research norms promote results that have nonmonetizable social value, such as robust debate and the free exchange of ideas. See, e.g., A.H. Goldman, Ethical Issues in Proprietary Restrictions on Research Results, in OWNING SCIENTIFIC AND TECHNICAL INFORMATION: VALUE AND ETHICAL IsSUES 69, 78 (Vivian Weil \& John W. Snapper eds., 1989) (arguing that the scientific ethic of openness is "a model of an open and free society"). Arguably, concerns unrelated to allocative efficiency are at least as important as any efficiency-oriented goals. Cf. Julie E. Cohen, Lochner in Cyberspace: The New Economic Orthodoxy of "Rights Management," 97 MiCH. L. REv. 462, 538-59 (1998) (developing social welfare function for information that includes nonmonetizable values). A noninstrumental analysis of the interaction between intellectual property rights and research norms would not, however, squarly address the efficiency-based arguments of those who have sought to chance research norms. In this Article, I will therefore focus on instrumental goals.

16 For a discussion of the "communality" norm, see infra note 67 and accompanying text.

17 By "full-blown intellectual property rights," I mean property rights on all invention that could be considered new, no matter how far removed from commercial application or easy to invent. This type of regime has been advocated by certain intellectual property theorists. See infra Part III.B.1. In addition, since 1980, changes in intellectual property law have pointed in this direction. See infra Part II.B. 


\section{LAW-AND-NORMS THEORY: AN INTRODUCTION}

A threshold question in law-and-norms theory is definitional: what is a norm? Most theorists use the term in more than a strictly descriptive sense. In their view, a norm is not simply observed behavior, "what people do," but rather behavior in which people engage out of a sense of obligation. 18 Further, norms are distinct from legal rules. While the violation of law is punished by state actors, the violation of norms is typically punished by private actors. ${ }^{19}$ Sanctions imposed on norm violators may include everything from informal gossip and disdain to formal exclusion from the group governed by the norms. ${ }^{20}$

Although specifying these characteristics narrows the scope of the term "norm," the wide range of contexts in which the term has been invoked nonetheless makes it difficult to formulate a precise definition. Robert Ellickson has used the term to discuss the informal rules of strict liability that farmers and ranchers in rural Shasta County, California use to address damage to crops caused by stray cattle. ${ }^{21}$ By contrast, other scholars have applied the term to describe the rules of various formal private legal systems, including the system developed in Japan to govern products liability ${ }^{22}$ and the system used by the National Grain and Feed Association to resolve contract disputes among its members. ${ }^{23}$ As David Charny has pointed out, ${ }^{24}$ these uses of the term differ in that some norms are created and enforced in a more centralized manner than others. Although Charny's observation is valid, it is incomplete in its neglect of the many arenas in which both centralized and decentralized mechanisms of norm creation and enforcement are at work. Moreover, centralized norms often have an interdependent relationship with less centralized ones. For example, in the context of scientific research, the centralized policies of research universities and professional organizations influence, and are influenced by, the practices of individual researchers. ${ }^{25}$

Both centralized and decentralized norms play an important role not only in law-and-norms theory, but also in a closely related branch of economic theory known as institutional economics. ${ }^{26}$ Institutional economics

\footnotetext{
18 See, e.g., Cooter, supra note 9, at 1656-67; Robert Cooter, Structural Adjudication and the New Law Merchant: A Model of Decentralized Law, 14 INT'L REV. L. \& ECON. 215, 220-21 (1994). But see ELLICKSON, supra note 3, at 127 (describing a norm more generally as a rule that has a social source).

19 See, eg., Eric A. Posner, Law, Economics, and Inefficient Norms, 144 U. PA. L. REV. 1697, 1699 (1996).

20 See David Chamy, Ilusions of a Spontaneous Order: "Norms" in Contractual Relationships, 144 U. PA. L. REV. 1841, 1841 (1996).

21 See ElliCKSON, supra note 3.

22 See Ramseyer, supra note 8.

23 See Lisa Bernstein, Merchant Law in a Merchant Court: Rethinking the Code's Search for Immanent Business Norms, 144 U. PA. L. REV. 1765 (1996).

24 See Chamy, supra note 20, at 1845.

${ }_{25}^{25}$ For examples of this interdependence, see infra notes 180,200 and accompanying text.

26 See generally THRÁINN EGGERTSSON, ECONOMIC BEHAVIOR AND INSTITUTIONS (1990); DOUGLASS C. NORTH, Institutions, INSTTIUTIONAL CHANGE, AND ECONOMIC PERFORMANCE (1990); ElINOR
} 


\section{NORTHWESTERN UNIVERSITY LAW REVIEW}

focuses on the role of institutions-defined broadly as "the humanly devised constraints that shape human interaction"27 - in facilitating a large variety of cooperative behavior. ${ }^{28}$ Norms, formal and informal, are prominently included within the set of institutions studied by institutional economics. ${ }^{29}$

Norms can be highly useful in overcoming obstacles to cooperative behavior. One of the most prominent obstacles is the collective action problem. In general, collective action problems arise when individuals can benefit from the provision of a collective good (e.g., a clean environment) without themselves contributing to the provision of that good (e.g., by refraining from littering or polluting). ${ }^{30}$ One mechanism for solving collective action problems is law-we could, for example, decide to impose fines on those who littered or polluted. ${ }^{31}$ But just as legal rules can discourage socially detrimental but individually rational activities such as littering or

OSTROM, GOVERNING THE COMMONS (1990); THE NEW INSTITUTIONALISM IN ORGANIZATIONAL ANALYSIS (Walter W. Powell \& Paul J. DiMaggio eds., 1991). According to Eggertsson, institutional economists divide into two camps. While "neoinstitutional" theorists add a heavy emphasis on transaction costs to the neoclassical economic model, they nonetheless accept its core elements of rational choice, stable preferences, and equilibria. See EGGERTSSON, supra, at 5-6. By contrast, "new institutional" theorists reject some of the core assumptions of the neoclassical model. Id. at 6,9 (noting that new institutional theorists replace the rational choice model of utility maximization with Herbert Simon's concept of "bounded rationality"). See also Rubin, supra note 3, at 1414 (discussing the inclusion within institutional economics of bounded rationality, "which posits that people's ability to make rational decisions is limited by the information they receive and by their own ability to process and communicate that information"). In this Article, I focus on the branch of institutional economics that Eggertsson terms "neoinstitutionalism." I do, however, invoke bounded rationality and other concepts from behavioral economics in discussing reasons for bargaining breakdown. See infra note 256 and accompanying text. For a summary of the central concepts in the behavioral economics literature, see Donald C. Langewoort, Behavioral Theories of Judgment and Decision Making in Legal Scholarship: A Literature Review, 51 VAND. L. REv. 1499, 1503-05 (1998) (discussing, inter alia, status quo and loss aversion bias, risk perception bias, context bias, egocentric bias, and causation bias).

27 NORTH, supra note 26 , at 3.

28 See EGGERTSSON, supra note 26, at 33-58 (discussing, in particular, the role of institutions in overcoming transaction costs); NoRTH, supra note 26, at 11-16 (discussing institutions as a response to both transaction costs and collective action problems); OSTROM, supra note 26 (discussing the emergence of institutions to overcome collective action problems). See also Merges, supra note 3, at 1320 21 (reviewing literature). The emphasis that institutional economic theorists place on transaction costs derives from Coase's theorem, which states that, for efficiency purposes, the initial allocation of rights does not matter so long as all rights are freely transferable, and there are no transaction costs associated with the transfer of rights. Ronald Coase, The Problem of Social Cost, 3 J.L. \& ECON. 1 (1960). The question of what constitutes a transaction cost has been the subject of some discussion. I follow the conventional account in defining transaction costs to include the costs associated with identifying potential buyers and sellers, negotiating deals, measuring performance, and enforcing agreements. See EGGERTSSON, supra note 26, at 14-16.

29 See, e.g., NORTH, supra note 26, at 36-45 (discussing "informal constraints"), 46-53 (discussing "formal constraints"). Because institutions can be either private or public, they represent a broader category of constraints than norms.

30 See generally MANCUR OLSON, THE LOGIC OF COLLECTIVE ACTION (1965).

31 Alternatively, we could have laws that gave extensive private property rights, so that the realm of what could be a collective good was considerably diminished. See, e.g., Harold Demsetz, Toward a Theory of Property Rights, 57 AM. ECON. REv. 347 (1967). 
polluting, so too can norms. ${ }^{32}$ Similarly, as institutional economist Elinor Ostrom has demonstrated in a wide variety of contexts, norms can address the specific collective action difficulty associated with conservation of common-pool resources such as water or fish. In particular, norms can discourage the overconsumption that would otherwise result from individually rational decisions. ${ }^{33}$

Norms can also play a role in reducing transaction cost barriers ${ }^{34}$ to cooperative exchange. For example, norms that emphasize reputation and loyalty can reduce the likelihood of cheating and thus reduce the transaction costs associated with enforcing agreements. ${ }^{35}$ Norms can also reduce the transaction costs associated with concluding an agreement. For example, conventions about how a contract should be implemented may allow parties to reach agreement more quickly, even over a somewhat incomplete contract. ${ }^{36}$

Given the ability of norms to serve many of the same functions as law, it is not surprising that some of the foundational literature on law and norms constitutes an attack on legal centrism. For example, Robert Ellickson's case study of rural farmers and ranchers argues that the strict liability norms used by these groups operate as an efficient alternative to law (which, at least in Shasta County, California, often does not mandate strict liability).

\footnotetext{
32 Of course, the fact that norms are useful at the collective level does not explain how they persist at the individual level. In the case of law, state-supported actors penalize the undesirable behavior. By contrast, in the case of norms-particularly informal norms enforced by individuals-it is not clear why any individual would want to incur the cost of penalizing others. In other words, the enforcement of norms itself poses a collection action problem. In response to this puzzle, some have argued that comprehensive external enforcement of norms may not be needed because individuals "internalize" norms; as a consequence of such internalization, they feel guilty when they violate a norm, even when others are unaware of the violation. See, e.g., Cooter, supra note 9, at 1661-63. Other scholars have argued that the primary mechanism through which norms are enforced-the denial of esteem to norm violators-is a costless way of punishing such violators. See McAdams, supra note 7, at 357 . According to McAdams, "denial of esteem" sanctions will enable norms to emerge and persist if three conditions exist: first, there is a consensus about the "esteem worthiness" of engaging in a particular behavior; second, there is some risk that engaging in that behavior will be detected; and third, individuals are aware both of the consensus and of the risk of detection. Id. at 358. The internalization thesis might provide an additional explanation for high levels of external norm enforcement. On this view, those who have intemalized a norm derive a psychological benefit from enforcing it, costlessly or otherwise. See Robert Cooter, Normative Failure of the Law, 82 CORNELL L. REV. 947, 957 (1997) (noting that intemalization may create "righteousness"- the willingness to punish other people).

${ }^{33}$ See OSTROM, supra note 26. In his famous article, Garrett Hardin illustrates how this overconsumption (which he terms the "tragedy of the commons") would arise. See Garrett Hardin, The Tragedy of the Commons, 162 SCIENCE 1243 (1968). Hardin envisions a pasture "open to all" from the perspective of a rational herder. Because the herder receives the full benefit of overgrazing while suffering only a small portion of its costs, it is individually rational for the herder to overgraze. One can also model Hardin's thought experiment in terms of game theory. See OSTROM, supra note 26, at 3, 46-47 (discussing prisoner's dilemma, "chicken," and "assurance" models).

${ }^{34}$ For a definition of transaction costs, see supra note 28.

${ }^{35}$ See NORTH, supra note 26 , at 55 .

${ }^{36}$ See id.
} 
Based in significant part on this case study, Ellickson makes the larger claim that norms are generally welfare maximizing. ${ }^{37}$

Subsequent law-and-norms scholars have diverged from Ellickson on two major grounds. First, they have argued that law and norms do not generally operate in separate spheres. Rather, they typically operate either to reinforce or to subvert each other. Some examples of the interaction between law and norms are fairly obvious: if the government passes a law forbidding smoking on airplanes, this law is likely to reinforce norms that independently deter smoking. Refraining from smoking gains the added attraction of being law-abiding behavior. ${ }^{38}$ In other cases, the effects that law has on norms are less obvious. For example, although the civil rights laws of the 1960 s probably undermined Southern norms that forbade the hiring or serving of African-Americans, they may have done so quite indirectly. As Lawrence Lessig has pointed out, what these laws did was "ambiguate" the social meaning of a southern businessman's economically selfinterested decision to hire or serve African-Americans. After the laws were passed, this decision could be construed not as a manifestation of greed or solidarity with African-Americans, but rather as simply following the law. ${ }^{39}$

37 See ElLICKSON, supra note 3, at 167. As Ellickson points out, the general idea of welfaremaximizing norms is not novel. Alexander Bickel, Lon Fuller, Friedrich Hayek, Thomas Schelling, and others have, in various ways, all emphasized the importance of nonlegal forces in contributing to the social order. See id. at 168 . The idea of effective decentralized ordering is also an important part of a rapidly growing branch of scientific theory known as complexity theory. Complexity theory is a companion to chaos theory that studies the ways in which spontaneous seif-organization can arise in a large variety of nonlinear dynamic systems, including systems that may exhibit chaotic characteristics. See M. MitChell WALDROP, COMPLEXITY: THE EMERGING SCIENCE AT THE EDGE OF ORDER AND CHAOS (1992). Scientists have applied complexity theory to physical, biological, and computer systems, see, e.g., STUART KaUfFMAN, THE ORIGINS OF ORDER: SELF-ORGANIZATION AND SELECTION IN EVOlution (1993); HEINZ R. PAGELS, THE DREAMS OF REASON: THE COMPUTER AND THE RISE OF THE SCIENCES OF COMPLEXITY (1988), and to social systems, see, e.g., THE ECONOMY AS AN EVOLVING COMPLEX SYSTEM (Philip Anderson et al. eds., 1988). For discussions of complexity theory in the legal literature, see David R. Johnson \& David G. Post, The New "Civic Virtue" of the Internet: Lessons from Models of Complex Systems for the Governance of Cyberspace, in THE EMERGING INTERNET 23 (Charles M. Firestone ed., 1998); J.B. Ruhl, The Fitness of Law: Using Complexity Theory to Describe the Evolution of Law and Society and its Practical Meaning for Democracy, 49 VAND. L. REv. 1407 (1996); J.B. Ruhl, Complexity Theory as a Paradigm for the Dynamical Law-and-Society System: A Wake-up Call for Legal Reductionism and the Modern Administrative State, 45 DUKE L.J. 849 (1996). For nontechnical introductions to complexity theory, see, for example, JOHN H. HOLLAND, HEDDEN ORDER: HOW ADAPTATION BUILDS COMPLEXITY (1995); STUART KAUTFMAN, AT HOME IN THE UNIVERSE: THE SEARCH FOR LAWS OF SELF-ORGANIZATION AND COMPLEXITY (1995).

${ }^{38}$ Of course, the act of abiding by the law itself reflects a norm.

39 See Lessig, supra note 3, at 966. See also Eric A. Posner, Symbols, Signals, and Social Norms in Politics and the Law, 27 J. LEGAL STUD. 765, 778-89 (1998) (discussing the related idea that the "signal" associated with certain actions, particularly symbolic actions, can change as the background law changes). The regulation of social meaning can become even more complicated. Consider, for example, the antebellum southem norm that encouraged duelling as a mechanism for resolving disputes within the upper class. If a southem state were to have passed a law banning duelling outright, this ban may not have had the effect of undermining the practice. Rather, the upper class that engaged in duelling may have considered it a point of honor to continue the practice, irrespective of the law. On the other hand, 
The second ground on which law-and-norms scholars have diverged from Ellickson is efficiency. There are many reasons to think that norms will not necessarily be efficient. As an initial matter, game-theoretic models of behavior predict that cooperative norms will emerge only if the players are small in number; ${ }^{40}$ have repeated, long-term interactions; can readily observe each other's moves; and do not discount the future too heavily. ${ }^{41}$ The empirical studies conducted by Ellickson and Ostrom indicate a similar, but even more stringent, prerequisite: not only must participants engage in repeated, readily observable interactions, but they must also have similar values and interests. Ellickson's farmers and ranchers were clearly a closeknit group with shared values and interests. ${ }^{42}$ Similarly, the most enduring models of common pool resource (CPR) management studied by Ostrom involved situations in which the group of resource appropriators was small and had very similar interests and values. ${ }^{43}$ Indeed, as a general matter, successful CPR management was dependent on small numbers and a similarity of interests. ${ }^{44}$ By contrast, CPR management failures were characterized by the presence of large groups with heterogenous interests. ${ }^{45}$

Repeated interaction within a close-knit group does not, however, guarantee efficiency. Even in this context, inefficient norms can emerge and persist if the parties involved in formulating and enforcing the norms have inadequate information or imperfect means by which to assess the information. ${ }^{46}$ In addition, even if a norm that is efficient for a particular group emerges, it may create negative externalities. For example, the exclusionary behavior of a particular social group may be efficient for that group, but it is not likely to be efficient for society as a whole. ${ }^{47}$ Indeed, because there

if the state were to have barred individuals who participated in a duel from public office, then the norm that favored duelling might have been brought into conflict with a norm that encouraged public service. In this more indirect fashion, the norm in favor of duelling may have been undermined. See Lessig, supra note 3, at 971-72.

${ }^{40}$ See NORTH, supra note 26, at 12.

41 See generally Cooter, supra note 18, at 218-19. Cooter models the emergence of cooperative norms in the context of an "investment game" in which participants who engage in strategic, noncooperative behavior will be punished in subsequent rounds of the game. This strategy is known as the "tit-for-tat" strategy. See generally ROBERT AXELROD, THE EVOLUTION OF COOPERATION (1984).

42 See ElLICKSON, supra note 3, at 3.

43 See OSTROM, supra note 26, at 88-89 (noting that "long-enduring" CPR institutions involve individuals who "have shared a past and expect to share a future .... None of those situations involves participants who vary greatly in regard to ownership of assets, skills, knowledge, ethnicity, race, and other variables that could strongly divide a group of individuals.").

44 See id. at 188. To the extent CPR management on a larger scale succeeded, this was because larger organizational units were built on previously organized smaller units. See id. at 189.

45 See id. at 146, 166.

46 See NORTH, supra note 26, at 8; Randal C. Picker, Simple Games in a Complex World: A Generative Approach to the Adoption of Norms, 64 U. CHI. L. REv. 1225, 1227 (1997); Posner, supra note 19, at 1711-25.

47 See, eg., Posner, supra note 19, at 1722-23; Cooter, supra note 18, at 225-26 (discussing racial discrimination and other "cartel" norms that are socially inefficient because of "spillovers to other communities"). 
is no reason to suppose that group norms will be efficient for those outside the group who are nonetheless affected by the group's activities, norms may often diminish overall social utility.

Finally, inefficient norms can remain in place because changing the norm is an activity that in itself poses a collective action problem. Even if everyone would be better off under the new, efficient norm, there may be no individual who is willing to risk the social disapproval or ostracism that comes with open criticism and violation of the existing norm. ${ }^{48}$ This collective action problem can arise even when there is no prior background norm in place. Because individuals can free-ride once the new, efficient norm emerges, they have no incentive to contribute to the creation of the new norm. ${ }^{49}$ In fact, empirical studies by institutional economists have demonstrated that the formation of institutions with cooperative norms can often be a time-consuming, laborious process. ${ }^{50}$

Given the evidence that law inevitably influences norms and that norms can be (and often are) inefficient, many scholars have called for state regulation or management of norms. ${ }^{51}$ On this argument, the state should use the law (and other tools at the state's disposal) to influence normspresumably to reinforce desirable norms and to subvert undesirable ones. ${ }^{52}$

\footnotetext{
48 See Lessig, supra note 3, at 1007 . The inefficient norms that remain in place may represent a 10 cal (as contrasted with global) maximum of efficiency. For example, even though it might be better for everyone in Britain to drive on the right side of the road-like the rest of the world-driving on the left represents a stable equilibrium for the British. See Cooter, supra note 18, at 225. Complexity theory (discussed supra note 37) yields similar conclusions about system efficiency or fitness. It modifies "classical" evolutionary theory by suggesting that a random approach to achieving system fitness may get "stuck" at a local fitness maximum. See, eg., Mark Roe, Chaos and Evolution in Law and Economics, 109 HARV. L. REV. 641, 643 (1996). As Roe points out, the idea of an inefficient, but stable, local equilibrium overlaps with the phenomenon of path dependence. The latter can be observed when a system that was once efficient survives not because of its current efficiency but because of the costs associated with change. Id. at 643 (giving example of winding road initially blazed by fur trader intent on avoiding wolf's den that survives despite the greater contemporary efficiency of a straight road). Path dependence is often associated with contexts that display strong "network effects"-that is, contexts in which the utility an individual derives from engaging in a particular activity depends on how many others are engaged in the activity. (For example, the utility of using a telephone is a function of how many others use telephones.) Because the utility of following a norm depends, at least in part, on how many others are also following the norm, norm-following behavior exhibits strong network effects.

49 See OSTROM, supra note 26, at 103 (observing that the formation of cooperative institutions to address collection action problems itself poses a second-order collective dilemma).

50 See generally id. at 111-26 (discussing repeated litigation that led to formation of water basin authorities for managing water from groundwater basins in southem Califomia). As Ostrom notes, state resources played a large role in the development of these water basin authorities. For further discussion of the state role, see infra notes 51-59 and accompanying text (discussing state "regulation" of norms).

51 See, e.g., McAdams, supra note 3, at 390-432; Posner, supra note 3, at 133-197; Sunstein, supra note 3, at $913-914$.

52 For staunch advocates of legal decentralization, the idea that the state should regulate norms may be controversial. But the arguments against norm regulation are problematic. Any system of law will inevitably have some effect on norms. See, e.g., Sunstein, supra note 3, at 913 (arguing that government "cannot avoid affecting norms"). There is no reason that the effect should be inadvertent and haphazard.
} 
The state may, for example, respond to inefficient norms by enacting laws that give individuals financial incentives to violate those norms. Once a critical mass of norm violators is reached, fairly rapid norm breakdown may result. $^{53}$ The state may also attack undesirable norms by putting those norms in conflict with other norms. This can be as simple as passing a law that conflicts directly with the undesirable norm. In that situation, the norm of engaging in law-abiding behavior may conflict with the undesirable norm to such a degree that the undesirable norm will be undermined. ${ }^{54}$ The state may also attempt to educate individuals about the harm of the norm, thus presumably reducing the degree to which the norm is internalized by citizens. $^{55}$ Moreover, if centralized institutions have some role in enforcing a particular norm, the state may use its influence to undermine those centralized institutions. ${ }^{56}$ These techniques may, of course, be used in reverse to reinforce positive norms.

The state can also facilitate the development of desirable cooperative norms by encouraging, or even subsidizing, the use of state institutions. In this regard, the work of Professor Ostrom is illustrative. One case study reviewed in detail by Ostrom involves a set of institutions that emerged to manage groundwater basins under the Los Angeles metropolitan area. Initially, because the legal rules regarding how much water each appropriator could withdraw were highly unclear, the result was predictable: each appropriator overused water. ${ }^{57}$ As this problem became apparent, and as attempts at voluntary agreement to reduce levels of water extraction failed, various municipal and private water appropriators initiated legal proceedings against other municipalities and private companies. In the shadow of impending or actual court orders, the municipalities and private companies were able to form associations that provided for water allocation. ${ }^{58}$ The state of California assisted the process not only by making its court system available, but also by subsidizing one third of the cost of legal proceedings. ${ }^{59}$

Moreover, if inefficient or otherwise undesirable norms are likely to stay in place absent government intervention, it is difficult to understand objections to such intervention.

${ }^{53}$ See id. at 930 . See also Posner, supra note 19, at 1729.

54 Of course, in those groups where rejection of law-abiding behavior is the norm, the passage of a law may simply strengthen the undesirable norm.

ss See, e.g, Lessig, supra note 3, at 668-70 (discussing state-funded educational campaigns against smoking and drugs and in favor of seat belts).

56 See generally Posner, supra note 3 .

57 See OSTROM, supra note 26, at 104-10.

58 See id. at 111-14, 116-23. Ostrom emphasizes that many of the "private" cooperative institutions she studied evolved with the assistance of the state. See id. at 14-15 ("Many CPR institutions are a rich mixture of 'private-like' and 'public-like' institutions defying classification in a sterile dichotomy."). See also id. at 182 ("Most of the institutional arrangements used in the success stories are rich mixtures of public and private instrumentalities. If this study does nothing more than shatter the convictions of many policy analysts that the only way to solve CPR problems is for external authorities to impose full private property rights or centralized regulation, it will have accomplished one major purpose.").

59 See id. at 138-39. 
In sum, a large literature demonstrates that behavior is governed not simply by positive law or social norms but by a complex and intimate interaction between the two systems. Lawmakers who wish to encourage particular behavior can therefore achieve their goal by using law to shape norms. Part II discusses an aggressive government effort to shape the behavior of the scientific research community that illustrates well some of the central tenets of law-and-norms theory.

\section{LAW AND NORMS IN BASIC MOLECULAR BIOLOGY RESEARCH}

The area of basic molecular biology research provides a new context in which to apply law-and-norms theory. Prior to the 1980s, this area of research was largely governed by the traditional norms of a relatively homogeneous academic scientific community. ${ }^{60}$ These traditional norms discouraged property rights in scientific invention and discovery. The law-both statutory law and case law-reinforced academic scientists and scientific institutions in their reluctance to secure property rights. Beginning in 1980, the legal framework surrounding scientific research shifted dramatically; at that time, the federal government embarked on a concerted effort to apply property-based incentives to scientific research. This effort changed significantly the traditional norms of scientific research. In this Part, I use law-and-norms theory to analyze the state's efforts and the substantial changes wrought by these efforts.

\section{A. Early Molecular Biology: The Centrality of Traditional Research Norms}

Molecular biology was originally conceived as a highly theoretical, abstract inquiry-in other words, as a quintessential basic science. The founder of the field, Warren Weaver, was a mathematical physicist who wished to apply the rigorously analytical methods of physics and chemistry to study "life" as a collection of such biological macromolecules as proteins and nucleic acids. As director of the Rockefeller Foundation's Division of Natural Sciences, Weaver began, in the early 1930s, to provide physicists and chemists at elite universities with the funding to study biological molecules. ${ }^{61}$

The molecular basis for one central "life" principle, the principle of inheritance, was identified in 1944 by Rockefeller University scientist Oswald Avery. The relevant molecule was deoxyribonucleic acid, or DNA. The significance of this discovery was limited, however, by the fact that no one knew how DNA worked to mediate inheritance. Indeed, even after James Watson and Francis Crick determined in 1953 that a double-helical

\footnotetext{
${ }^{60}$ See infra Part II.A.

61 See generally MARTIN KENNEY, BIOTECHNOLOGY: THE UNIVERSITY-INDUSTRIAL COMPLEX 1013 (1986); Robert TeItelman, PROfits of SCIENCE: The AMERICAN MARRIAGE OF BUSINESS AND TECHNOLOGY 181-83 (1994).
} 
structure elegantly served DNA's functional purposes by encoding cell protein structure and permitting error-free reproduction of itself, the science of molecular biology was still far from practical commercial application. The non-commercial nature of molecular biology was reflected in the way that research in molecular biology was funded. For the most part, such research was conducted in academic institutions and funded by either the government or by nonprofit foundations. ${ }^{62}$ Meanwhile, in the drug industry, cash flows derived from a small group of pharmaceutical products that had, for the most part, not been discovered through basic scientific investigation of molecular mechanisms. ${ }^{63}$

Given the manner in which molecular biology research was conducted, it was perhaps inevitable that such research would largely be guided by traditional basic science norms. ${ }^{64}$ A number of sociologists of science, principally Robert Merton, Bernard Barber, and Warren Hagstrom, have provided influential-and strikingly similar-characterizations of these norms. ${ }^{65}$ Traditional scientific norms promote a public domain of freely available

62 See KENNEY, supra note 61, at 13-18. "Using constant 1972 dollars, funding of university research grew at annual rates of $12 \%$ from 1953 to 1960 [and] 14\% from 1960 to 1968 ." Robert M. Rosenzweig, Research as Intellectual Property: Influences Within the University, $10 \mathrm{SCl}$. TECH. \& HUM. VALUES 41, 43 (1985).

${ }^{63}$ See TEITELMAN, supra note 61 , at 180-81, 184.

64 As one observer of the biotechnology community has noted, the govemment's role in funding basic research fostered a "powerful ideology" in which "industry's motives-especially that of profitability-were suspect." KENNEY, supra note 61, at 32. See also Sheila Slaughter \& Gary Rhoades, The Emergence of a Competitiveness Research and Development Policy Coalition and the Commercialization of Academic Science and Technology, 21 SCI. TECH. \& HUM. VALUES 303, 307-09 (1996) (noting that, prior to the 1980s, missions of various governmental funding agencies reinforced scientific norms).

65 See BARBER, supra note 1; WARREN O. HAGSTROM, THE SCIENTIFIC COMMUNITY (1965); Robert K. Merton, The Normative Structure of Science, in ROBERT K. MERTON, THE SOCIOLOGY OF SCIENCE (1973). See also Eisenberg, supra note 12, at 182-84 (discussing in particular the work of Robert Merton). These sociologists use the term "norm" in both a descriptive and prescriptive sense. In other words, for these sociologists, norms represent not only what people actually do but also what people think they should do. The sociological use of the term "norm" thus comports with the manner in which it is used in the law-and-norms literature. See supra text accompanying note 18.

Even before commercialization and intellectual property issues began to influence scientific research, some critics made arguments that the descriptions of the scientific community given by these sociologists were idealized and inaccurate. See, e.g., Nico Stehr, The Ethos of Science Revisited: Social and Cognitive Norms, in SOCIOLOGY OF SCIENCE 172 (Jerry Gaston ed., 1978). However, the fact that individuals in a group may depart from group norms occasionally does not mean that the norms do not exist or have moral and psychological force. Rather, norms will persist so long as norm violations are relatively infrequent and are met with disapproval from the relevant community. See Eisenberg, supra note 12, at $183 \mathrm{n} .17$ (discussing scientific community's disapproval of norm violations). Moreover, as discussed further infra text accompanying notes 79-81, behavior that violates certain scientific norms may be tolerated because it is perceived as being in the service of other norms. On the other hand, it bears mention that some of the methodological norms described by Merton in particular are vulnerable to criticism. For example, Merton's argument that scientists routinely subject new claims of scientific knowledge to rigorous scrutiny, see Merton, supra, at 277, is not bome out by the empirical evidence. See generally WILLIAM BROAD \& NichOLAS WADE, BETRAYERS OF THE TRUTH (1982). See also discussion in note 75 , infra. 
scientific information, independent choice in the selection of research topics, and (perhaps above all) respect for uninhibited scientific invention.

One central element of the scientific ethos that promotes the sharing of information in the public domain is the view that scientific knowledge is ultimately a shared resource. This norm has variously been termed "communism" or "communalism." Communalism means that

substantive [scientific] findings ... constitute a common heritage in which the equity of the individual producer is severely limited. An eponymous law or theory does not enter into the exclusive possession of the discoverer and his heirs, nor do the mores bestow upon them special rights of use and disposition. Property rights in science are whittled down to a bare minimum by the rationale of the scientific ethic. The scientist's claim to "his" intellectual "property" is limited to that of recognition and esteem ... ${ }^{68}$

The communal character of science is also manifested in a recognition by scientists of their dependence upon a cumulative cultural heritage. Newton's famous remark-'If I have seen farther it is by standing on the shoulders of giants"-reflects this sense of indebtedness to predecessors. ${ }^{69}$

In light of this value of communality, claiming property rights in invention is often seen as immoral. ${ }^{70}$ The same can be said of secrecy." The scientist takes from the cumulative knowledge accumulated by her predecessors and is therefore under a moral obligation to publish any discoveries that build upon the goods that have been given to her. ${ }^{72}$ Secrecy can do serious

\footnotetext{
66 Merton, supra note 65, at 273-75.

67 BARBER, supra note 1, at 92. See also HAGSTROM, supra note 65, at 99 (noting that "[s]cientific
} knowledge is community property"). As Barber points out, the norm of communality is also closely connected with the idea of "disinterestedness": scientists are expected to achieve their self-interest by serving the community interest-that is, by "making contributions to the development of conceptual schemes which are of the essence in science." BARBER, supra note 1, at 92. See also Merton, supra note 65, at 275-77 (advancing a similar definition of disinterestedness).

68 Merton, supra note 65, at 273 (emphasis added). See also DAVID DiCKSON, THE NEW POLITICS OF SCIENCE $89-90$ (1984) (noting that academic researchers traditionally rejected patenting because, in their view, they were paid to disseminate knowledge to the public).

69 Merton, supra note 65, at 274-75. As Merton notes, Newton's aphorism can be traced historically to at least the twelfth century. Even Thomas Kuhn, who argues that scientific revolutions are non-cumulative transitions between incommensurable world views, stresses that "normal science"-which represents the vast majority of scientific research-is cumulative. See THOMAS KUHN, THE STRUCTURE OF SCIENTIFIC REVOLUTIONS 52, 96 (1962). Because proving the inventiveness of one's own work is extremely important, however, communalism does not lead to generosity in giving others credit. See infra text accompanying note 79. To the contrary, scientists may even try to claim credit for ideas that did not originate with them. The competition for credit becomes particularly intense in the context of major scientific prizes such as the Nobel Prize. See Jon Cohen \& Gary Taubes, The Culture of Credit, 268 SCIENCE 1706 (1995).

${ }^{70}$ See generally BARBER, supra note 1, at 153-54.

71 See generally Sissela Bok, Secrecy and Openness in Science: Ethical Considerations, SCI. TECH. \& HUM. VALUES 32 (1982).

72 See BARBER, supra note 1, at 91. For example, even during World War II, the British joumal Nature published the Declaration of Principles of the Conference on Science and World Order, which 
damage to scientific inquiry by limiting feedback and verification; it can also "foster[ ] needless duplication of effort[ [."73 As a consequence, the range of circumstances in which secrecy is considered acceptable is quite narrow. ${ }^{74}$

Other established norms of science promote not only verification of scientific results but also independent inquiry. One of these norms may be termed "individualism" or "independence." In the context of scientific inquiry, individualism does not stand in opposition to teamwork; rather, it means that scientists are free to set their own research agendas and to criticize the work of others. ${ }^{75}$

emphasized the publication of research results. The seventh principle emphasized that the pursuit of scientific inquiry demanded unrestricted international exchange. Free exchange was described as the lifeblood of science, and restrictions were labeled foolish or destructive. See The Commonwealth of Science, 148 NATURE 3753 (1941). Similarly, in 1959, in response to a letter from Senator Thomas Henning, chairman of the Senate Judiciary Committee, Subcommittee on Constitutional Rights, various American Nobel Prize winners expressed some of the following thoughts on security restrictions limiting the free flow of United States science. Glenn T. Seaborg commented:

I think that if there is any conclusion upon which all scientists have complete agreement it is that exchange of information is vital for maximum progress and elimination of wasted motion. Also, since, among human pursuits, science is almost unique in being inmediately transferable across national boundaries, exchange of information must be considered on a global basis.

Edward C. Kendall suggested the consequences of restrictions on exchange:

The objective of all creative research is to enlarge the horizon which circumscribes the fund of knowledge in the world of science. The best situation in the best of possible worlds would be rapid dissemination of all new work. The information thus made available would, of itself, be a powerful stimulus .... As a dismal contrast one merely has to go to the other possible extreme. In such a world, investigators in all research laboratories and medical institutions would work behind locked doors. No results would be published, all workers would be isolated, all publicity by the association of science writers would be suppressed. Interest in science would decrease, the tempo and scale of research would slow down, a feeling of indifference and hopelessness would crush initiative, a moratorium on progress would ensue.

Views on Secrecy Given by American Nobel Prize Winners, 130 SCIENCE 85-86 (1959).

73 See Bok, supra note 71, at 33.

74 As Warren Hagstrom's empirical study of scientific behavior notes, "[n]ot many informants confessed secretive behavior. This is partly because such secrecy conflicts more or less with the norms of free communication in science; secrecy itself must usually be kept secret." HAGSTROM, supra note 65 , at 88 .

75 See BARBER, supra note 1, at 89-90, 144; HAGSTROM, supra note 65 , at 105, 111-20. Just because scientists are free to challenge one another's work does not mean, however, that they routinely do so. Many factors militate against such challenges: the prior researcher may not have published her results in replicable form, the number of investigators capable of replicating the research may be small, or the professional benefits of replication may be small or nonexistent relative to the benefits of new invention. See Rebecca S. Eisenberg, Patents and the Progress of Science: Exclusive Rights and Experimental Use, 56 U. CHI. L. REV. 1017, 1049-50 (1989). More generally, as Thomas Kuhn has famousiy argued, researchers in a particular field typically do not challenge the prevailing theories, or paradigms, in their field. Rather, they typically spend their careers solving scientific puzzles within the framework of these paradigms. See generally KUHN, supra note 69, at 23-51 (describing this process of puzzlesolving as "normal science"). Scrutiny of prior research is likely to occur only in those relatively rase circumstances when anomalies-empirical observations that appear fundamentally to challenge the prevailing paradigm-emerge. See id. at 52-65. During the ensuing "crisis," the scientific community scrutinizes critically both the embattled paradigm and possible competitors. See id. at 77-79. Kuhn's argument is significant because it calls into question not only traditional assumptions in the sociology of science but also certain philosophical views of science. See, e.g., SIR KARL POPPER, THE LOGIC OF 
NORTHWESTERN UNIVERSITY LAW REVIEW

Finally, perhaps the strongest norm is that of invention itself. While those who adhere to the norms of communalism and individualism will merit some admiration (and those who violate these norms will be disapproved of), the highest levels of recognition and prestige are bestowed upon those who make original contributions to the common stock of knowledge. ${ }^{76}$ The greater the significance of the scientist's original contribution, the greater the recognition that she receives. ${ }^{77}$ The norm of invention leads scientists to compete vigorously to be the first to present an invention or discovery to the scientific community. ${ }^{78}$

Invention is so highly prized that violations of other norms may be tolerated in its name. For example, aggressively competitive behavior that seems contrary to the norm of communalism may be tolerated when invention is at stake. ${ }^{79}$ Likewise, one context in which secrecy is considered acceptable is when there is competition for priority in achieving and disclosing a particular research result. A canonical example of such pre-publication secrecy was the reluctance of James Watson and Francis Crick, in their competition with Linus Pauling and others to discover the structure of DNA, to release their research results until absolutely necessary. ${ }^{80}$ Emphasis on invention may also lead scientists to publish too quickly and thereby violate their obligation to present only verified results to the scientific community. ${ }^{81}$

The rationale for all of these scientific norms is to further the institutional goal of science, which is the progress of knowledge. ${ }^{82}$ The norm of invention clearly fosters such progress directly. The communalism norm is also perceived by research scientists as fostering such progress, because it gives all scientists unimpeded access to the information necessary to do further research. ${ }^{83}$

Basic scientific research norms share many similarities with the norms of academic institutions generally. Freedom of inquiry, a public domain of

SCIENTIFIC DISCOVERY (1992) (describing the scientific endeavor as a continuous series of attempts to "falsify" prior theories through empirical observation).

76 See, e.g., HAGSTROM, supra note 65, at 13, $23-42$.

77 See id. at 69-85. The emphasis on originality also contributes to the free flow of information: scientists are pressured to publish as soon as possible in order to avoid being preempted by others who are working on similar projects. See id.

${ }^{78}$ See id. at 69-104.

79 See generally Cohen \& Taubes, supra note 69.

80 See generally JAMES WATSON, THE DOUBLE HeLIX: A PERSONAL ACCOUNT OF THE DisCOVERY OF THE STRUCTURE OF DNA (1980) (discussing competition with Linus Pauling).

81 See HAGSTROM, supra note 65, at 99-100.

82 See, eg., Stehr, supra note 65, at 176 (noting that norms "enhance the institutional goal of science, which is the continuing extension of certified knowledge claims"); Merton, supra note 65, at 270 (noting that the norms of science further the development of knowledge). Indeed, some sociologists of science have argued that the norms of science are fundamentally determined by its specialized cognitive development and conceptual structure. See Stehr, supra note 65, at 179-82 (collecting sources).

83 See BARBER, supra note 1, at 153 (discussing statement by university scientists that "patents will place unfortunate stricture on other men who subsequently do fundamentally important work in the same field"). 
knowledge, and the growth of knowledge have historically been prized not only in basic science, but also in the world of academe. The overlapping norms of academe and of basic science played a major role in bringing basic science into the university several centuries ago. ${ }^{84}$ As a mechanism for preserving traditional scientific norms, the marriage of basic science and the university has largely been harmonious. Institutional academic policiesboth policies specifically directed towards scientific research and general academic policies-reinforce the practices of individual scientists and are themselves reinforced by such practices.

It is perhaps not surprising that research norms emphasizing the public domain held sway when basic molecular biology research was far from market application. What is more surprising is that these norms continued to operate even as the science of molecular biology matured and the ease with which commercial products could be derived from the underlying science increased. ${ }^{85}$ Commercial enterprises are not, after all, committed to the principle of sharing knowledge. To the contrary, vigorously defended patent rights and trade secrets are an accepted part of business practice. ${ }^{86}$

Despite the prospect of commercial applications for inventions, traditional scientific norms stayed reasonably intact. Although industry began to conduct some basic molecular biology research, it was not intimately involved in the enterprise of academic research. Rather, as discussed further below, ${ }^{87}$ industry was wary of becoming involved in federally funded, university-based research until significant legal change occurred-specifically, until Congress changed the law so as to ensure that universities would have property rights in the results of such research. ${ }^{88}$

The experiences of those who invented the pioneering techniques of commercial biotechnology illustrate the early lack of emphasis on property rights. When Stanley Cohen and Herbert Boyer of Stanford University invented gene-splicing ${ }^{89}$ in 1973 , they patented the technique only after strenuous urging by the university's patent counsel. Cohen and Boyer also required that the university be the exclusive beneficiary of royalty revenue and that the patent be licensed widely, to all those who sought a license. As

\footnotetext{
84 See Clifford Grobstein, Biotechnology and Open University Science, 10 SCI. TECH. \& HUM. VALUES 55, 57 (1985).

${ }^{85}$ See TEITELMAN, supra note 61, at 8 (discussing narrowing of gap between science and commercial application).

${ }^{86}$ See Leonard G. Boonin, The University, Scientific Research, and the Ownership of Knowledge, in OWNING SCIENTIFIC AND TECHNICAL INFORMATION, supra note 15, at 253, 263.

87 See infra II.B.1.

88 Indeed, one of the explicit goals of the legislation that allowed universities to retain patent rights in the results of their research was promoting "collaboration between commercial concerns and nonprofit organizations." 35 U.S.C. $\$ 200$ (1994) (policy and objectives section of the Bayh-Dole Act).

89 The gene-splicing technique involves the insertion of a specific gene into a host cell. The host cell then expresses the protein for which the gene codes. See Stanley N. Cohen et al., Construction of Biologically Functional Bacterial Plasmids In Vitro, 70 PROC. NAT'L ACAD. SCI. 3240 (1973).
} 
a result, the knowledge remained, at least to some extent, in the public domain. ${ }^{90}$ Cohen later commented, "My initial reaction ... was to question whether basic research of this type could or should be patented and to point out that our work had been dependent on a number of earlier discoveries by others." Similarly, as late as 1975, Georges Köhler and Cesar Milstein, who shared the Nobel Prize for the groundbreaking development of monoclonal antibody technology, ${ }^{92}$ determined that it would be ethically inappropriate to patent their technique. ${ }^{93}$ Indeed, in a 1979 Congressional hearing on patenting and scientific research, biomedical researchers argued that "“the natural impulse ... [of] the university person is to give away information as rapidly as possible. After all, that is why he is in the university. And that is really what he is rewarded for." ${ }^{\prime 94}$ As described in the next section, these attitudes would soon be altered quite dramatically by changes in intellectual property law.

\section{B. Changes in Intellectual Property Law}

The factor that most directly spurred norm change was not market influence but legal change-specifically, changes in intellectual property law. ${ }^{95}$ Starting in the mid-1970s, legal and economic opinion began to shift toward a more favorable view of strong intellectual property rights. ${ }^{96}$ Legal developments that strongly favored patenting by universities emerged both in the statutory law and the case law. The statutory changes took the form of various technology transfer statutes that Congress enacted, starting with the Bayh-Dole $\mathrm{Act}^{91}$ in 1980. The pro-patent case law emerged largely from the Court of Appeals for the Federal Circuit (CAFC or Federal Cir-

90 See Rebecca S. Eisenberg, Public Research and Private Development: Patents and Technology Transfer in Government-Sponsored Research, 82 VA. L. REV. 1663, 1710 (1996).

91 Boonin, supra note 86, at 262.

92 Monoclonal antibody technology involves the fusing of immune system cells that generate antibodies to particular antigens with immortal cancer cells. See G. Kobler \& C. Milstein, Continuous Cultures of Fused Cells Secreting Antibody of Predefined Specificity, 256 NATURE 495 (1975).

93 See KENNEY, supra note 61 , at 129. In addition, the British Medical Research Council required that such methods be freely available to others. See Boonin, supra note 86, at 262-63.

94 The University and Small Business Patent Procedures Act: Hearings on S.414 Before the Senate Comm. on the Judiciary, 96th Cong. 81 (1979) (statement of Dr. Leland Clark, Professor of Research Pediatrics, Children's Hospital Research Foundation, Cincinnati, Ohio) [hereinafter University Patent Hearings].

95 It bears emphasis, however, that industry (both small and large business) did strongly influence Congress's decision to change intellectual property law. The influence of industry is discussed further infra notes 109, 116 and accompanying text.

96 See J.H. Reichman, Computer Programs as Applied Scientific Know-How: Implications of Copyright Protection for Commercialized University Research, 42 VAND. L. REV. 639, 643 \& n.12 (1989) (citing academic articles from the late 1970 s and the 1980s that were favorable to strong intellectual property rights).

97 Bayh-Dole Act, Pub. L. No. 96-517, § 6(a), 94 Stat. 3015, 3019-28 (1980) (codified as amended at 35 U.S.C. $\S \S 200-212(1994))$. 
cuit), which hears all patent appeals. Indeed, Congress's creation of the Federal Circuit in $1982^{98}$ was driven by Congress's desire to unify and strengthen the patent law. ${ }^{99}$ As discussed below, the pro-patent legislation and case law had an immediate, and quite significant, effect on norms.

1. Changes in Statutory Law: Bayh-Dole and Beyond. Prior to 1980 , government policy regarding the patenting of research results that emerged from federally sponsored research in universities was fairly consistent with conventional scientific research norms. Although some federal agencies allowed university patenting of federally sponsored research, ${ }^{100}$ the process of obtaining the right to patent was generally cumbersome and complex, ${ }^{101}$ and thus the number of cases in which patenting occurred was small. ${ }^{102}$ Starting in 1980, however, Congress decided that the goal promoted by traditional research norms-putting research results in the public domainwas inefficient, at least with respect to the aim of developing marketable products. ${ }^{103}$ On this view, inefficiency resulted because private firms had

98 See Federal Courts Improvement Act of 1982, Pub. L. No. 97-164, 96 Stat. 25 (codified as amended at 28 U.S.C. $\S \S 41$ et seq. (1982)).

99 See generally discussion infra Part II.B.1.

100 See Eisenberg, supra note 90, at 1683 (noting, for example, that the Department of Health, Education, and Welfare granted patent rights to universities with approved patent and technology transfer capabilities).

101 See S. REP. NO. 96-480, at 2 (1979) (observing that "[i]n general, the present patent policies require contractors and grantees to allow the funding agency to own any patentable discoveries made un. der research and development supported by the Federal Government unless the contractor or grantee successfully completes lengthy waiver procedures justifying why patent rights should be left to the inventor"). This Senate report on the "University and Small Business Patent Procedures Act," which eventually became the Bayh-Dole Act, also observed that "[p]resently, there are at least 24 different patent policies in effect in the Federal agencies. These are frequently contradictory from agency to agency (and even sometimes within the same agency) and have proven to be formidable barriers to organizations interested in participation in Government work." Id. at 2.

102 See infra text accompanying note 181 (noting that, before 1980, only about 250 patents per year were granted to universities). Indeed, even at a major research university like Stanford, the technology transfer office consisted of three full-time employees: a manager of technology licensing, an associate, and an administrative assistant. See University Patent Hearings, supra note 94, at 210 (statement of Niels Reimers, manager of technology licensing, Stanford University). See also id. at 70 (statement by Dr. Hector F. DeLuca, chairman of biochemistry department, University of Wisconsin, Madison, that "there is no reward to a scholarly scientist at a university for patents filed").

103 See H.R. REP. No. 96-1307, pt. 1, at 3 (1980) (arguing that the patent rights conferred by the Bayh-Dole Act were necessary to develop inventions to the point of commercial application). See also Eisenberg, supra note 90, at 1664 (discussing Congressional determination that "[i]f the results of federally sponsored research were to be rescued from oblivion and successfully developed into commercial products, they would have to be patented and offered up for private appropriation"). From the perspective of law-and-norms theory, the fact that research norms were inefficient in terms of producing marketable products is not surprising. Norms developed and enforced by academic research scientists would have no reason to take into account concems about marketable products. See supra text accompanying note 47 (discussing idea that norms of a particular group will be efficient only with respect to the goals of the members of the group). It bears mention, however, that Congressional skepticism regarding the value of leaving information in the public domain may have been overstated. One survey of seven industries indicates that even before the passage of the Bayh-Dole Act, recent academic research 
little incentive to spend resources on developing research inventions into marketable products so long as those research discoveries were in the public domain for anyone to use. A firm could be assured of profiting from its expenditures only if it could secure a competitive advantage, that is, only if it could, through exclusive licensing of the patented invention, appropriate the discovery for itself. ${ }^{104} \mathrm{Or}$, to put the point more sharply, monopoly rights in inventions were seen as necessary not for the traditional reason that such rights would provide an incentive to invent, ${ }^{105}$ but rather as an incentive for private firms to undertake the further investment necessary to translate the inventions into marketable products. Congress also believed that the failure to patent publicly funded basic science had allowed foreign competitors to take that basic science and use it to develop a variety of commercial products. $^{106}$ To redress these perceived failures in commercialization, Congress began to pass various pieces of pro-patent technology transfer legislation. ${ }^{107}$

The most important of these was the Bayh-Dole Act, ${ }^{108}$ which Congress passed in 1980. Bayh-Dole explicitly gave universities the right to seek patent rights on the results of their federally sponsored research and to retain patent ownership themselves. ${ }^{109}$ Moreover, by requiring that univer-

was critical to the development of about $10 \%$ of industry products and processes. See Edwin Mansfield, Contribution of New Technology to the Economy, in TECHNOLOGY, R \& D, AND THE ECONOMY, supra note 1 , at 125 .

104 See H.R. REP. No. 96-1307, pt. 1, at 3, 5 (1980) (noting importance of exclusive licensing for attracting risk capital necessary for development). See also Eisenberg, supra note 90, at 1669; Rebecca S. Eisenberg, A Technology Policy Perspective on the NIH Gene Patenting Controversy, 55 U. PITT. L. REV. 633, 634-36 (1994). Under the patent statute, the patentee (or its licensee) has the exclusive right to make, use, sell, offer for sale, or import the invention described in the claims of the patent. 35 U.S.C. $\S 271$ (1994). A patent is defined in terms of its claims.

${ }_{105}$ For further discussion of this traditional justification for intellectual property rights, see infra Part III.A.

106 See S. REP. NO. 96-480, at 1 (1979) (stating, in "Purpose" section of report on Bayh-Dole bill, that "[e]vidence is mounting that the United States is falling behind its intemational competition in the development of new products and inventions .... The number of U.S. patents granted to foreigners has risen since 1973 and now accounts for 35 percent of all patents issued in this country."). See also 35 U.S.C. $\S 200$ (1994) (noting that one purpose of the Bayh-Dole Act of 1980 was "to promote the commercialization and public availability of inventions made in the United States by United States industry and labor") (emphasis added); Eisenberg, supra note 90, at 1665; Eisenberg, supra note 104, at 636.

107 Indeed, many historians of science have identified the year 1980 as a turning point in United States science and technology policy. Starting in 1980, commercial competitiveness became the central rationale for publicly funded research and development. See, eg., Slaughter \& Rhoades, supra note 64, at 304.

${ }_{108}$ Pub. L. No. 96-517, \& 6(a), 94 Stat. 3015, 3019-28 (1980) (codified as amended at 35 U.S.C. $\S \S 200-212$ (1994)).

10935 U.S.C. $\$ 202$ (a), (c)(4) (1994). Specifically, in order for the transfer of title to take place, the university contractor has to agree to file a patent application prior to any statutory bar date. Id. Under Bayh-Dole, an agency may, "in exceptional circumstances," formulate a funding agreement that does not transfer title of patentable inventions to the university. This exception is discussed further infra text accompanying notes $346-47$. In response to pressure from industry, the Bayh-Dole Act (originally known as the University and Small Business Patent Procedures Act) also gave small businesses the right to seek patents on the results of their federally funded research. See, e.g., Government Patent Policy: Hearings Before the Subcomm. on Science, Research and Tech. of the House of Representatives Comm. on Science and Tech., 96th Cong. 45-190 (1979) (testimony of large and small business witnesses) 
sities share patent royalties with individual inventors, ${ }^{110}$ the Act gave not only universities but also individual inventors an incentive to be on the lookout for patentable inventions. The Act also encouraged universities to license their patents by giving the agency sponsoring the research the authority to require the licensing of patented inventions. ${ }^{\text {II }}$

Although the traditional justification for patent rights had been that they provide incentives to invent, Bayh-Dole was not particularly concerned about invention in itself. Rather, the stated policy objective of Bayh-Dole was "to use the patent system to promote the utilization of inventions arising from federally supported research or development."112 On this view, although universities did not have the resources to commercialize research discoveries themselves, the grant of patent rights would allow them to attract exclusive licensees with the resources to undertake such commercialization. ${ }^{113}$

[hereinafter Government Patent Policy]. Congress was quite taken by the "very impressive recond in technological innovation" compiled by small businesses. S. REP. No. 96-480, at 1 (1979). In enacting the Bayh-Dole Act, Congress rejected proposed legislation (S.1215) that would have extended the right to seek patents to large businesses (in addition to universities and small businesses). Not surprisingly, large businesses testified in favor of such legislation. See, eg., Government Patent Policy, supra, at 5354 (statement of John Maurer, Patent Counsel at Monsanto, arguing that "patent exclusivity is equally important for research done in universities, small businesses and large businesses. In fact, large businesses are often the only places which have the skill for some types of research and the resources to support long-term innovation. It simply would be self-defeating to limit a sound patent policy to only universities and small businesses"). Large business interests were not defeated for long, however. In 1983, the right to retain patent ownership of federally sponsored research was extended to large businesses. See Eisenberg, supra note 104, at 637.

11035 U.S.C. $\$ 202$ (c)(7)(b) (1994).

11135 U.S.C. $\$ 203$ (1994).

i12 35 U.S.C. $\$ 200$ (1994) (emphasis added). Although incentives to invent were not the focus of the legislation, Bayh-Dole nonetheless served the agenda of those who wished to stimulate scientific invention through private rather than public funding. Indeed, backers of Bayh-Dole predicted that private funding would flow into universities once university patent rights on federally-funded research were secure. See infra note 116. Moreover, after Bayh-Dole was enacted, the federal role in funding academic research and development declined. While the federal government funded $69 \%$ of such research and development in 1973, by 1993 it funded only 56\%. See Slaughter \& Rhoades, supra note 64, at 327.

${ }^{113} 35$ U.S.C. $\$ 200$ (1994) (stating that Bayh-Dole was intended "to promote collaboration between commercial concems and nonprofit organizations"). The technology transfer argument does not, of course, require that patent rights be given to universities. Presumably the government could also retain title to the discoveries and could attempt to secure development through exclusive licensing to commercial interests. One major reason that patent rights were given to universities was the poor record the government appeared to have in getting its patent portfolio licensed for commercial development. Even where the government had patent rights, it licensed them nonexclusively. See S. REP. No. 96-480, at 28 (1979) (noting that because nonexclusive licenses were generally viewed dismissively in the business community, "as no patent protection at all," only $4 \%$ of the 28,000 patents owned by the government had been licensed to private industry for development). In addition, as discussed in the text, proponents of Bayh-Dole argued that if the government retained patent rights, academic researchers would not devote time and energy to identifying, and developing, patentable inventions. 
As law-and-norms theory might suggest, ${ }^{114}$ those who advocated giving patent rights to universities treated traditional scientific research norms as obstacles that could be overcome through the material inducement of patent rights. Specifically, they argued that the prospect of royalties would motivate university researchers, who were primarily focused on the rewards of publication, to devote time and energy to technology transfer - that is, to the commercialization of technology. By contrast, if title were vested in the government, university researchers would not spend time identifying patentable inventions that could then be commercialized. ${ }^{115}$ Of even greater importance to advocates of patent rights was the assurance such rights would provide to industry. Only when industry was satisfied that universities had secure patent rights would it provide funding for research related to the federally funded research; only then would industry become less fearful that it might lose patent rights to commercially interesting discoveries that emerged from such research (or even patent rights to its own prior research in the area). ${ }^{116}$

In effecting norm change, the federal government did more than simply change the law with respect to universities. It also invoked the changed law to lead by example. ${ }^{117}$ In June 1991, the National Institutes of Health (NIH) invoked a provision of the Bayh-Dole Act that allowed federal agencies to apply for, and hold title to, patents on the results of that intramural research. ${ }^{118}$ Specifically, Dr. Craig Venter, then of the NIH, attempted to se-

114 See supra text accompanying notes 52-54 (discussing idea that the government can undermine a norm by creating incentives to violate the norm).

115 As one hearing witness from the university community noted, "Under Govemment ownership of patents, there is no feedback of funds to the institution or to the inventor and thus the inventor is deprived of an important inducement to conceive and develop inventions." University Patent Hearings, supra note 94, at 69 (statement of Dr. Hector F. DeLuca, chairman of the Biochemistry Department, University of Wisconsin, Madison). Similarly, the patent counsel for General Electric observed that "[u]nless the universities get substantial rights from patents, there is absolutely no incentive for them to establish technology transfer and patent programs which may lead to commercialization of the research." See Patent Policy: Hearings on S.1215 Before the Subcomm. on Science, Tech., and Space of the Senate Comm. on Commerce, Science, and Transp., 96th Cong. 302 (1979) (statement of H.F. Manbeck, Jr., General Patent Counsel, General Electric Co.).

116 Congress was acutely aware of the industry position on this matter. See S. REP. NO. 96-480, at 21-22 (1979) (stating that "[m]any small companies have told the committee that they are reluctant to use university research facilities because they fear that any resulting patent rights might be 'tainted' if the university is also receiving Federal support in related research"). The report also emphasized that "[e]ven the receipt of a small percentage of Federal money" would confuse the question of patent ownership and decrease industry interest in collaborating with universities. Id. at 21, 22 (noting that "President Carter has stated that the creation of a 'partnership' between universities and industry is a goal of Federal science and technology policy .... However, without fundamental changes in Government patent policies regarding university research, any substantial improvement [in university/industry relations] is doubtful.").

117 Cf. supra text accompanying note 55 (discussing norm change through educational campaigns sponsored by the state).

118 See 35 U.S.C. $\$ 207$ (1994). The NIH also invoked the Stevenson-Wydler Innovation Act, Pub. L. No. 96-480, 94 Stat. 2311 (1980) (codified at 15 U.S.C. § 3701 (1980)), passed the same year as the 
cure patents on several thousand gene fragments of unknown function that he had sequenced. ${ }^{119}$ The NIH justified its support of Dr. Venter's patent applications by invoking the development-oriented theory of Bayh-Dole. Thus, according to the $\mathrm{NIH}$, the patenting of gene fragments could promote the development of commercially useful products. Commercial development would occur because the government would give private firms exclusive licenses to use particular fragments; these exclusive licenses would, in turn, make it possible for firms to use the fragments to develop products that would be too risky to pursue if the fragments were left in the public domain and were thus free for potential competitors to use. ${ }^{120}$

The view that the dominant purpose of property rights is not to spur invention but rather to spur efficient development and commercialization of invention has been very influential not only in technology transfer law but also in the case law. ${ }^{121}$ In the next section, I discuss the manner in which

Bayh-Dole Act, which specifically directed federal agencies to strive for technology transfer through patenting and licensing. The Federal Technology Transfer Act, Pub. L. No. 99-502, § 2, 100 Stat. 1785087 (1986) (codified as amended at 15 U.S.C. $\$ \S 3710 \mathrm{a}(1)$, (b)(2)-(3) (1994)), then amended the Stevenson-Wydler Act to authorize government-operated laboratories to enter into cooperative research and development agreements (CRADAs) with industry and to agree in advance to assign patents on inventions made by federal employees to the collaborating firm. Id.

119 Academics widely discussed Dr. Venter's bid for patents. See, e.g., Christopher Anderson, NIH Drops Bid for Gene Patents, 263 SCIENCE 909 (1994); Smith \& Kettelberger, supra note 1; Paul J. Riley, Comment, Patenting Dr. Venter's Genetic Findings: Is the National Institutes of Health Creating Hurdles or Clearing the Path for Biotechnology's Voyage into the Twenty-First Century, $10 \mathrm{~J}$. CONTEMP. HEALTH L. \& POL'Y 309 (1994).

${ }^{120}$ See Smith \& Kettelberger, supra note 1, at 46. As discussed further below, Dr. Venter's effort failed. The Patent and Trademark Office (PTO) turned down those particular applications on the grounds that the sequence fragments did not meet statutory criteria for patentability. See infra text accompanying notes 156-60. In February 1994, the NIH decided that it would not appeal the PTO determination. Dr. Harold Varmus, the new NIH Director appointed by the recently elected Clinton administration, said that pursuing patents on partial sequences would not be "in the best interests of the public or science." Anderson, supra note 119, at 909. In general, in the last few years, NIH policy has shifted towards greater support of the public domain; indeed, in some respects, the NIH scientific leadership has led the scientific community's resistance to extensive property rights in science. See infra notes 345-52 and accompanying text.

121 Many commentators have observed that the judicial expansion of intellectual property rightsan expansion that has occurred not only in patent law but also in copyright-is largely based on, or at least explained by, this view. See, e.g., Mark Lemley, Romantic Authorship and the Rhetoric of Property, 75 TEX. L. REV. 873, 898-903 (1997) (discussing cases that reflect a development-oriented approach towards information); Neil W. Netanel, Copyright and a Democratic Civil Society, 106 YALE L.J. 283, 306-24 (1996) (discussing "neoclassicist" view of copyright, which focus on the efficient allocation of development and commercialization resources through strong intellectual property rights). See also In re Alappat, 33 F.3d 1526, 1571 (Fed. Cir. 1994) (Newman, J., concurring) (quoting approvingly statement by Irving S. Shapiro, Chairman, E.I. duPont de Nemours \& Co., that "no matter how much money we spend on research and development, the findings are not going to benefit the public unless there are suitable incentives [for] commercialization"); Foreword to DONALD CHISUM ET AL., PRINCIPLES OF PATENT LAW: CASES AND MATERIALS, iii (1998) (statement by Federal Circuit Court Judge Giles Rich that the most important function of the patent system is "to encourage the investment of risk capital in the commercialization of inventions"). 
changes in the case law-in particular, changes that emerged from Congress' creation of the Court of Appeals for the Federal Circuit in 1982dramatically expanded the amount of basic research that could be patented.

2. Changes in Case Law: The Impact of the Federal Circuit. Historically, the case law reinforced traditional scientific norms by discouraging the private appropriation of basic research discoveries. Patent law largely steered clear of basic research and focused instead on applied technology. This focus on applied technology derived in part from the language of the Constitution, which authorizes Congress "to promote the Progress of Science and useful Arts, by securing for limited Times to Authors and Inventors the exclusive Right to their respective Writings and Discoveries."122 This provision was typically read in a manner that tied promoting the progress of science (knowledge generally) to copyright law and the progress of the "useful Arts" (applied technology) to patent law. ${ }^{123}$ Under this parsing of its language, the Constitution authorized Congress to extend patent protection to applied technology only.

In a number of important cases decided before the advent of Bayh-Dole, the Supreme Court applied the congressional definition of patentable subject matter-"any new and useful process, machine, manufacture, or composition of matter, or any new and useful improvement thereof"124 -in a manner that clearly limited its scope to applied technology. In the 1972 case Gottschalk v. Benson, ${ }^{125}$ for example, the Supreme Court rejected a patent on a computerized method for converting binary-coded (BCD) numerals to pure binary numerals on the grounds that patent protection did not apply to abstract scientific or mathematical principles and formulae (including mathematical algorithms embodied in computer software). Then, in the 1978 case Parker v. Flook, ${ }^{126}$ the Court invoked the rule against patenting mathematical algorithms to reject as unpatentable subject matter a method for calculating (and updating) the limits that should be reached on certain variables (e.g., temperature, pressure, and flow rates) during hydrocarbon catalytic conversion processes. Interestingly, the Court justified these determinations on grounds similar to those used to explain the research norm of communality. It noted that scientific principles and mathematical for-

122 U.S. CONST. art. I, $\S 8, \mathrm{cl} .8$.

123 See, e.g., In re Bergy, 596 F.2d 952, 958 (C.C.P.A. 1979), aff'd sub nom, Diamond v. Chakrabarty, 447 U.S. 303 (1980) ("[T]he constitutionally stated purpose of granting patent rights to inventors for their discoveries is the promotion of progress in the "useful Arts' rather than in science."). See also Edward Waltersheid, To Promote the Progress of Science and the Useful Arts: The Background and Origin of the Intellectual Property Clause of the U.S. Constitution, 2 J. INTELL. Prop. L. 1, 51 (1994) (arguing that the term "useful Arts" was used to signify "helpful or valuable trades").

12435 U.S.C. \$ 101 (1982).

125409 U.S. 63 (1972).

126437 U.S. 584 (1978). 
mulae are the "basic tools" of science and technology, on which all scientists must draw. ${ }^{127}$

At the time, the patentability of basic research was also significantly limited by the statutory requirement of "utility"128 -the idea that the invention must be operable and have some practical application. ${ }^{129}$ In the 1966 case Brenner v. Manson, ${ }^{130}$ for example, the Supreme Court held that a patent applicant had to demonstrate a specific and practical utility for a claimed invention. ${ }^{131}$ The fact that the claimed invention was being investigated for possible therapeutic use-specifically, for possible tumorinhibiting effects in mice-did not satisfy the utility standard. ${ }^{132}$ In Bren-

${ }^{127}$ See id. at 589. See also Benson, 409 U.S. at 67 . Similarly, some legal scholars have argued against the patentability of mathematical algorithms on the grounds that infringement of algorithm patents could occur through mere thinking. See, e.g., Pamela Samuelson, Benson Revisited: The Case Against Patent Protection for Algorithms and Other Computer Program-Related Inventions, 39 EMORY L.J. 1025, 110809, 1123-28 (1990). In the specific area of basic molecular biology research, the scope of patentable subject matter may also have been constrained to some extent by the belief that all living materials were "products of nature" and thus were not patentable. See Diamond v. Chakrabarty, 447 U.S. 303, 311 (1980) (noting petitioner's argument that Congressional understanding of patentable subject matter did not include living things). In Chakrabarty, however, the Supreme Court made it clear that living things were patentable: the Court held that a living bacterium that degraded crude oil was patentable subject matter because it had been genetically engineered and did not exist in nature. For purposes of the patentable subject matter determination, the relevant distinction was not between living and non-living materials, but rather "between products of nature, whether living or not, and human-made inventions." Id. at 313.

12835 U.S.C. $\S \S 101$ (1982). To the extent that the patent clause of the Constitution focuses on "useful Arts," the statutory utility requirement may have a constitutional dimension. See Stitung v. Renishaw PLC, 945 F.2d 1173, 1180 (Fed. Cir. 1991).

129 In addition to patentable subject matter and utility, the patent statute mandates that all patentable inventions fulfill three other conditions. These are "novelty," "nonobviousness," and disclosure. 35 U.S.C. $\S \S 103,112$ (1994). Novelty requires that the invention not have been preceded by an identical prior invention. Nonobviousness requires that the invention represent an advance over prior invention that would not have been obvious to a person of "ordinary skill in the art" The Supreme Court has suggested that because Congress's patent power is limited to promoting progress in the useful arts, the novelty and nonobviousness requirements may have a constitutional dimension. On this view, Congress may not, as a constitutional matter, "authorize the issuance of patents whose effects are to remove existent knowledge from the public domain, or to restrict free access to material already available." Graham v. John Deere, 383 U.S. 1, 5 (1966). Finally, adequate disclosure requires that the patentee provide a clear written description of the invention (the "written description" requirement); and that she describe the manner of making and using it in a manner that "enable[s] any person skilled in the art" to make and use it (the "enablement" requirement). Traditionally, written description and enablement have differed in that the written description requirement generally applies to later-filed claims, while enablement applies to the original patent claims. See, e.g., Vas-Cath, Inc. v. Mahurkar, 935 F.2d 1555, 1571 (Fed. Cir. 1991) (the written description requirement is intended to "guard against the inventor's overreaching by insisting that he recount his invention in such detail that his future claims can be determined to be encompassed within his original creation"). For further discussion of these requirements, see infra note 176 and accompanying text.

${ }^{130} 383$ U.S. 519 (1966).

131 See id. at 534-35 (noting that the invention had to demonstrate that a "specific benefit exists in currently available form...").

132 See id. at 529-531. In Brenner, the invention at issue was a process that produced a steroid. The Court held that because the only disclosed use of the steroid was in further scientific testing, the process that produced the steroid was also unpatentable. See id. at 535. 
ner, the Court raised questions that lie at the heart of the communalism norm: it expressed the concern that conferring patent rights in basic research discoveries would create a "monopoly of knowledge" and "confer power to block off whole areas of scientific development, without compensating benefit to the public."133 The Brenner Court also noted approvingly the proposition that "a patent system must be related to the world of commerce rather than to the realm of philosophy."134

The turning point in the case law came in 1980, the same year that the Bayh-Dole Act was passed. In that year, the Supreme Court's decision in Diamond v. Chakrabarty ${ }^{135}$ heralded a more favorable attitude towards patents, including patents on basic research. Although the Chakrabarty case itself did not involve basic research, it did declare boldly that patentable subject matter "include[d] anything under the sun that is made by man."136 In addition, in the 1981 case Diamond $v$. Diehr, ${ }^{137}$ the Court essentially reversed Parker $v$. Flook by upholding as patentable subject matter a process for curing synthetic rubber that relied on a well-known mathematical algorithm (the Arrhenius equation) for the calculation of the appropriate cure time. ${ }^{138}$ Again, although Diehr did not itself involve basic research, it did suggest that the Court would allow patenting of all inventions that moved even slightly in the direction of applied work.

Chakrabarty and Diehr notwithstanding, however, the Supreme Court's role in determining the scope of what is patentable has been rather limited. The major force behind the shift towards greater patentability, including greater patentability of basic research, has been the Court of Appeals for the Federal Circuit. In 1982, Congress created the Federal Circuit in response to concerns that the widely divergent patent decisions of the various regional federal courts of appeal had led to extensive forum shopping and uncertainty

${ }^{133}$ Id. at 534. The discussion in the text focuses on the Supreme Court's strict interpretation of the specific statutory requirement of utility. Arguably, however, the Supreme Court was generally hostile to patents during this period. As early as 1949, Justice Jackson noted a "strong passion in this Court for striking [patents] down[,] so that the only patent that is valid is one which this Court has not been able to get its hands on." Jungerson v. Ostby \& Barton Co., 335 U.S. 560, 572 (1949) (dissenting opinion).

134383 U.S. at 536.

135447 U.S. 303 (1980).

136 Id. at 309 (quoting S. REP. No. 82-1979, at 5 (1952); H.R. REP. No. 82-1923, at 6 (1952)). In so doing, the Court put to rest any lingering doubts about whether living materials could be patented.

137450 U.S. 175 (1981).

138 Technicaliy, the Court did not reverse Flook. Rather, it purported to distinguish Flook by noting that the method at issue in that case involved updating an "alarm limit," and an alarm limit was "simply a number." Diehr, 450 U.S. at 186. By contrast, the patent applicants in Diehr sought patent protection for "the transformation of an article, in this case raw, uncured synthetic rubber, into a different state or thing... ." Id. at 184. However, as the dissent in Diehr emphasized, the invention in each case was essentially the same-a mechanism for computing values that had to be known in order for the physical conversion process at issue in the case to operate properly. Id. at 209-10 n.31 (Stevens, J., dissenting). Indeed, just as the Flook patent was drafted as a patent for updating a mere number-an alarm limit-the Diehr patent could readily have been drafted as a method for calculating a mere number-cure time. Id. at 210 n. 32 . 
about patent enforcement. ${ }^{139}$ In keeping with the philosophy behind BayhDole and other pro-patent technology transfer legislation, proponents of a single forum for patent appeals argued that the stronger patent rights created by a more uniform interpretation of the patent law were necessary for economic growth and international competitiveness. ${ }^{140}$

The Federal Circuit has in fact strengthened patent rights quite significantly. ${ }^{141}$ One manner in which it has done so is by expanding the domain of patentable subject matter. For example, in a recent decision, State Street Bank \& Trust Co. v. Signature Financial Group, ${ }^{142}$ the Federal Circuit emphasized that mathematical algorithms are patentable so long as they produce a "useful" result, even if the result does not apply to, or is not limited by, any physical elements or process steps. ${ }^{143}$ In so doing, the CAFC squarely rejected a well-established doctrine, devised by the CAFC's predecessor, the Court of Customs and Patent Appeals, in response to the Supreme Court's decisions in Flook and Diehr. That doctrine, known as the Freeman-Walter-Abele doctrine, had allowed algorithms to be patented only in those situations in which they were applied to particular elements or process steps. ${ }^{144}$ The State Street decision also went significantly beyond the Diehr decision itself. The algorithm at issue in Diehr had clearly been limited to a specific physical process for curing rubber. ${ }^{145}$

Moreover, although the Federal Circuit has retained the idea that "products of nature" per se are not patentable, it has routinely upheld pat-

\footnotetext{
139 The legislative history of the law that created the Federal Circuit indicates that Congress wanted to "increase doctrinal stability in the field of patent law." S. REP. No. 97-275, at 5 (1981). See also H.R. REP. No. 97-312, at 20-21 (1981) (noting that "some circuit courts are regarded as 'pro-patent' and other[s] 'anti-patent' and [that] much time and money is expended 'shopping' for a favorable venue"); Rochelle Cooper Dreyfuss, The Federal Circuit: A Case Study in Specialized Courts, 64 N.Y.U. L. REV. 1, 6-7 (1989) (arguing that prior to establishment of Federal Circuit, forum shopping was rampant, patents were often held invalid, and 'the research community considered the value of patents to be in decline"). For example, in the period from 1945-57, a patent was four times more likely to be enforced in the Seventh Circuit than in the Second Circuit. See Dreyfuss, supra, at 7. Moreover, the Supreme Court rarely reviewed the divergent decisions of different federal courts of appeals. See id. at 6 .

140 See Ninth Annual Judicial Conference of the Court of Customs and Patent Appeals, 94 F.R.D. 350, 358-9 (1982) (statement of Rep. Kastenmeier).

141 See, e.g., Donald R. Dunner et al., A Statistical Look at the Federal Circuit's Patent Decisions: 1982-1994, 5 FED. CR. B.J. 151, 154 (1995) (stating that "[t] he most notable trend ... is that, in district court cases, the Federal Circuit was significantly more likely to affirm judgments in favor of patent owners than accused infringers"); Mark A. Lemley, An Empirical Study of the Twenty-Year Patent Term, 22 AIPLA Q.J. 369 (1994) (noting that patents are more likely to be held valid by the Federal Circuit than they had been by circuit courts in previous decades).

142149 F.3d 1368 (Fed. Cir. 1998).

${ }^{143}$ Id. at 1373. In State Street, the Federal Circuit rejected a subject matter challenge to a patent on a computerized accounting system used to manage a mutual fund investment structure. The court argued that the final share price produced by the accounting system was "useful" for regulatory authorities and in subsequent trades. See id.

144 See id. at 1374 (describing, and rejecting, test).

145 See supra note 138.
} 
ents on purified and isolated forms of molecules that occur in nature. ${ }^{146}$ Included in this category are patents on purified and isolated full gene sequences whose physiological function (i.e., the protein for which they code) has been identified. ${ }^{147}$

Admittedly, full gene sequences whose physiological function has been identified do not necessarily represent basic research-after all, the research gap between the gene sequence and a commercial therapy may not be large. Moreover, the idea of granting patents on purified and isolated form of products that occur in raw form in nature has been around for a long time. ${ }^{148}$ The widespread granting of patents on full gene sequences is nonetheless important, however, because it has spurred efforts to patent smaller pieces of DNA that are significantly further away from practical commercial application. These include gene fragments, typically of unknown function, which will typically be used as probes to locate and characterize the full gene. Advocates are now arguing that these gene fragments-known as expressed sequence tags (ESTs)-constitute patentable subject matter. Some genome companies-most prominently Incyte, Inc. and Human Genome Sciences, Inc.-have filed patent applications on hundreds of thousands of such ESTs. ${ }^{149}$ Many of these EST applications are notable for the broad scope of their patent claims: the applications claim not only the EST but also the full gene of which it is a part and future uses of the gene. ${ }^{150}$

\footnotetext{
146 See, e.g., Genentech, Inc. v. Wellcome Found. Ltd., 29 F.3d 1555, 1558 (Fed. Cir. 1994) (discussing patent on purified form of tissue plasminogen activator (t-PA), a naturally occurring protein that helps dissolve fibrin clots in human body); Scripps Clinic \& Research Found. v. Genentech, Inc., 927 F.2d 1565 (Fed. Cir. 1991) (patent on highly purified form of Factor VIII:C, a naturally occurring factor involved in human blood clotting process).

147 See, e.g., Genentech, Inc. v. Chiron Corp., 112 F.3d 495 (Fed. Cir. 1997) (litigation involving patent on DNA sequence coding for human insulin growth factor-I, a growth-promoting protein that mediates the effects of human growth hormone); Amgen, Inc. v. Chugai Pharm. Co., 927 F.2d 1200 (Fed. Cir. 1991), cert. denied, 592 U.S. 856 (1991) (litigation involving patent on a purified and isolated gene sequence encoding human erythropoietin). Human Genome Sciences, Inc. (HGS), a commercial genomics research firm, now has patents on twenty-seven full-length genes that code for a variety of different proteins. See Clive Cookson, Rival Strategies Race to Unravel Genetic Code, FINANCIAL TIMES, May 27, 1998, at 10. The coding function of a gene sequence is performed by the DNA base pairs of which it consists. The order and type of the DNA bases determines which protein is coded for. The purified and isolated gene sequence that is considered patentable differs from the DNA base pair sequence that is found on the chromosome in nature. The major difference consists in the fact that the patentable gene has been isolated and separated from the surrounding DNA on the chromosome. The surrounding DNA is considered "junk" DNA because it apparently has no coding function.

148 See, e.g., Parke-Davis \& Co. v. H.K. Mulford Co., 189 F. 95 (C.C.S.D.N.Y. 1911) (upholding patent grant on adrenalin purified and isolated from suprarenal glands of animals).

149 See Eliot Marshall, Patent Office Faces 90-Year Backlog, 272 SClENCE 643 (1996) (noting that, according to Incyte's chief scientific officer, the company has filed applications on over 400,000 sequences).

150 See Christopher Anderson, A New Model for Gene Patents, 260 ScIEnce 23 (1993). As discussed further infra notes 254-69 and accompanying text, whether or not these broad claims are granted, EST patent owners will in all likelihood have significant influence over future research related to the gene of which the EST is a part. The granting of broad claims would give EST patent owners even greater influence over all future research. Whether broad claims will in fact be granted is another ques-
} 
Commercial firms are also seeking patents in many other areas of basic genetic research. One prime focus of patent application is single nucleotide polymorphisms (SNPs). ${ }^{151}$ SNPs represent those areas in which human genomes differ by only one DNA base pair from one another. It is estimated that there are approximately 300,000 SNPs in the human genome. ${ }^{152}$ Scientists predict that SNPs will be particularly useful in the identification of the multiple genes underlying such complex disorders as diabetes, hypertension, asthma, common cancers, and the major neuropsychiatric diseases. The genes will be identified through the association of particular SNP markers with individuals who have a particular polygenic disease. ${ }^{153}$ SNPs and other genetic variations may also be useful in predicting patients' responses to prescription drugs. Currently, for reasons scientists do not fully . understand, a significant proportion of patients either do not respond to certain drugs or develop side effects from their use. ${ }^{154}$ Although SNPs show much commercial and therapeutic promise, SNP research is, thus far, in its initial stages. Most of the SNPs that have been discovered have not been linked to particular diseases or patient responses. The patent applications that companies are filing are therefore largely on SNPs of unknown function-in other words, on the SNPs that are properly considered basic research.

Other much-discussed subjects of patenting are cell membrane receptors that could be implicated in the etiology of particular diseases and thus could be targets for drugs directed at those diseases. Indeed, patents have already been issued on some of these receptors. ${ }^{155}$ Given what has happened with ESTs, SNPs, and cell receptors, we have every reason to expect broad patent applications on other routine, low-cost molecular biology in-

tion. The Federal Circuit's biotechnology jurisprudence suggests that broad claims will fail the written description requirement. See infra note 263. The PTO's recent grant of an EST patent to Incyte Pharmaceuticals is not entirely clear as to whether the patent is limited only to the EST fragments themselves or conveys broader rights. See NIH Finds Incyte EST Patent "Disturbing": Venter Sounds Database Concerns, THE BLUE SHEET, Dec. 9, 1998 [hereinafter Incyte Patent].

151 See Eliot Marshall, Snipping Away at Genome Patenting, 277 SCIENCE 1752 (1997).

152 See Stephen D. Moore, Staying Ahead: Genset Scientist Bets on Dense Mapping for Firm's Future, WALL ST. J. EUR., Jan. 27, 1999, at 1.

153 These associations can be made through automated scans of the complete genome of many individuals with the polygenic disease in question. See Francis Collins et al., Variations on a Theme: Cataloging Human DNA Sequence Variation, 278 SCIENCE 1580 (1997). As the authors of this article point out, SNP association studies "should be particularly efficient for identification of genes with relatively common variants that confer a modest or small effect on disease risk-precisely the type of gene expected in most complex disorders." Id. at 1581. The issue of SNP patentability has become particularly urgent because recent approaches to assessing DNA sequence differences between individuals are expected to reduce the cost and increase the rate at which SNPs can be discovered. Id.

154 See Moore, supra note 152 . Unpredictable patient response can cause problems not only in the marketing of dugs but also in the clinical testing process. Ninety percent of drugs fail clinical testing because of side effects or an inability to demonstrate sufficient efficacy among patients taking the drug. See id.

${ }^{155}$ See John H. Barton, Patents and Antitrust: A Rethinking in Light of Patent Breadth and Sequential Innovation, 65 ANTITRUST L.J. 449, 449 (1997). 
ventions that are relatively "upstream"-that is, far removed from practical commercial application.

Of course, even if an EST, SNP, or target receptor constitutes patentable subject matter, it does not necessarily qualify for a patent. The basic research has to satisfy a variety of additional tests. One of these tests is utility. The PTO rejected Dr. Craig Venter's applications for patents on various ESTs ${ }^{156}$ of unknown function on the grounds that the fragments did not meet this test. ${ }^{157}$ Although Dr. Venter's applications speculated that the claimed inventions could be put to a variety of uses, the PTO concluded that "[t] he mere mention of possible uses is not sufficient to establish a definite utility."158 Moreover, the most credible utility claims-the claims that the DNA fragments could be used as probes to obtain full gene sequences and as chromosome markers-were vulnerable to the challenge that such applications were merely research uses, not the "specific benefit . . . in currently available form" required by the Supreme Court in such cases as Brenner v. Manson. ${ }^{159}$ Arguably, under the Brenner v. Manson standard, the ESTs would not have practical utility until the actual function of the full genes with which they were associated had been identified. ${ }^{160}$

The rejection of the applications submitted by Dr. Venter did not, however, settle the question of EST patentability. To the contrary, in 1995, the PTO announced new guidelines on utility that lowered the threshold for such a finding. ${ }^{161}$ Then, in 1997, the PTO announced that it was ready to grant patents on ESTs. ${ }^{162}$ Although the PTO's 1997 announcement indicated that it would require patent applications to assert more than the "mere allegation of utility ... as a probe,"163 it is likely that EST applications that provide some support for their utility claims (and also meet the other requirements for patentability) will be successful, at least at the PTO level. ${ }^{164}$ Notably, the fact that the utility of a particular EST lies primarily in its research value-rather than in a specific commercial application-may not

\footnotetext{
156 For discussion of this application, see supra note 119 and accompanying text.

157 See generally Eisenberg \& Merges, supra note 1.

158 Id. at 14 (quoting PTO observation). The PTO emphasized that actually putting the ESTs to many of the claimed uses would require further experimentation and interpretation, in contravention of the utility standard. Id. at 14-15.

159 See id. at 18-19, 51-52 (making this argument).

160 Id. at 18.

161 See PTO Utility Examination Guidelines, 60 Fed. Reg. 36, 263 (1995) (asserting that rejection for lack of utility is inappropriate if the applicant makes an assertion of utility that would be credible to a person or ordinary skill in the field or if the invention has a well-established utility). See also Eric C. Woglom \& Margaret A. Pierri, U.S. is Unifying Utility Requirements, NAT'L J., Feb. 20, 1995, at C3738.

162 See Ed Susman, U.S.P.T.O. To Allow Patents on Gene Fragments Called ESTs, BIOTECHNOLOGY NEWSWATCH, Mar. 3, 1997, at 1.

163 Lynn Pasahow \& Andrew Kumamoto, Human Genome Project Raises Patenting Issues, NAT'L LAW J., Oct. 20, 1997 at C31 (quoting PTO announcement).

164 See id.
} 
pose an obstacle to patentability. ${ }^{165}$ Indeed, in November 1998 , Incyte Pharmaceuticals announced that it had been granted an EST patent. ${ }^{166}$

The PTO's recently expanded view of utility is in keeping with the Federal Circuit's liberalization of the utility requirement. The court has determined that inventions that are quite far away from commercial applicability can nonetheless demonstrate utility. Federal Circuit decisions have held, for example, that if a novel compound demonstrates activity of apparent therapeutic/pharmacological value in vitro (i.e., outside a living environment), such activity can be sufficient to establish its practical utility. ${ }^{167}$ According to the Federal Circuit, demonstration of in vitro activity is sufficient if it establishes a probability that subsequent in vivo testing (testing in a living environment, which is further down the line towards commercialization) will be successful. ${ }^{168}$ The Federal Circuit has also emphasized that "[u]sefulness in patent law, and in particular the context of pharmaceutical inventions, necessarily includes the expectation of further research and development."169

Above all, however, the Federal Circuit's use of the doctrine of "nonobviousness" has significantly strengthened patent rights in biotechnology. Nonobviousness requires that a patentable invention represent an advance over the prior art that would not have been obvious to someone of "ordinary skill in the art." the PTO's determination that DNA sequences of genes that code for particular proteins are obvious (and hence not patentable) when the amino acid sequence of the protein, as well as a general method for identifying genes through the use of nucleotide probes, are known. ${ }^{171}$ In so doing, the Federal Circuit has ignored determinations by the PTO's patent examiners, who are skilled in the art of biotechnology, that "when the [amino acid] sequence of a protein is placed into the public domain, the gene is also placed into the public domain because of the routine nature of cloning techniques."172 The Federal Circuit has justified its decisions by. arguing that, with respect to a

165 See Susman, supra note 162 (noting statement by deputy patent commissioner Lawrence Goffney that ESTs may be patented based on their utility as probes for locating full genes).

${ }^{166}$ See Incyte Patent, supra note 150. It bears mention, however, that unlike some companies seeking EST patents, Incyte has identified the function of the proteins to which the 44 ESTs that it claims correspond. The proteins are ail enzymes known as kinases that regulate cell proliferation, differentiation, and signalling by adding phosphate groups to proteins. See Patent No. 5, 817, 479, Human Kinase Homologs.

167 See Cross v. lizuka, 753 F.2d 1040 (Fed. Cir. 1985).

168 See id. at 1050. The lizuka court also reaffirmed the well-accepted proposition that structural similarity to pharmacologically active compounds can establish utility. Id. at 1049.

${ }^{169}$ In re Brana, 51 F.3d 1560, 1568 (Fed. Cir. 1995). In that same case, the court also noted that the requirements for finding a compound useful within the meaning of the patent laws are quite different from (and more lenient than) the requirement of clinical efficacy necessary for obtaining governmental approval to market a particular drug for human consumption. Id.

17035 U.S.C. $\$ 103$ (1994).

171 See, e.g., In re Deuel, 51 F.3d 1552 (Fed. Cir. 1995); In re Bell, 991 F.2d 781 (Fed. Cir. 1993).

172 Ex parte Deuel, 33 U.S.P.Q.2d 1445 (Bd. Pat. App. \& Interf. 1993) (citing the views of PTO examiners). 
patent claim to a DNA sequence, the nonobviousness determination must focus on the DNA molecules as chemical compounds rather than on the method for isolating them. ${ }^{173}$ Specifically, according to the CAFC, a given DNA sequence is obvious only if the prior art actually recites a similar or identical sequence and not simply a method for isolating the sequence. ${ }^{174}$

Of course, as noted earlier, ${ }^{175}$ the full DNA sequence that codes for a particular protein is not necessarily basic research. However, the Federal Circuit's reasoning makes it likely that all DNA-based discoveries, including such basic discoveries as ESTs and SNPs of unknown function, will be deemed nonobvious so long as there are no similar DNA sequences already in the public domain. This approach lowers the bar for patentability dramatically. In the EST context, for example, ESTs will likely be deemed nonobvious even though the biotechnological methods for obtaining ESTs have been well known in the literature since $1991 .^{176}$

173 See Deuel, supra note 171, at 1559 ("The PTO's focus on known methods for potentially isolating the claimed DNA molecules is also misplaced because the claims at issue define compounds, not methods." (citing In re Bell, 991 F.2d 781, 785 (Fed. Cir. 1993)).

174 The Federal Circuit's argument is based on its view that DNA-based technology is simply a subset of chemical technology. In the chemical context, the conventional test for obviousness of a chemical product is "structural similarity" to previous chemical products. See, e.g., In re Dillon, 919 F.2d 688, 692 (Fed. Cir. 1990). According to the Federal Circuit, the structural similarity test applies equally well to biotechnology. Deuel, supra note 171, at 1557-58 ("Because Deuel claims new chemical entitics in structural terms ... a prima facie case of obviousness is based on structural similarity, i.e., an established structural relationship between a prior art compound and the claimed compound."). For a critique of the Federal Circuit's approach that argues DNA should be treated not as a chemical compound but, rather, as information, see Arti K. Rai, Intellectual Property Rights in Biotechnology: Addressing New Technology, 34 Wake Forest L. Rev. 827, 836 (1999).

175 See supra text accompanying note 148.

176 Eisenberg \& Merges, supra note 1, at 34-35. The CAFC's liberalization of the nonobviousness requirement has been offset to some extent, however, by the greater strictness with which the court has applied the requirement that the patentee provide a clear written description of her invention. See supra note 129 (discussing written description and other disclosure requirements). For example, in Regents of the Univ. of Cal. v. Eli Lilly \& Co., 119 F.3d 1559 (Fed. Cir. 1997), a case involving the use of recombinant DNA technology to produce human insulin, the Federal Circuit broke new ground by applying the written description requirement not only to later-filed claims, see supra note 129 , but also to claims filed in the original patent. Specifically, the court scrutinized the University of California's original claim to a human-insulin-coding DNA sequence for compliance with the written description requirement. It then used an unusually strict construction of the written description requirement to hold that the University of California had to actually isolate and sequence the human DNA sequence in order to describe it adequately. Describing a method for isolating the DNA sequence was not sufficient. See Lilly, 119 F.3d at 1567. In essence, the Lilly court used the written description requirement as a type of heightened enablement requirement. See Janice M. Mueller, The Evolving Application of the Written Description Requirement to Biotechnological Inventions, 13 BERKELEY TECH. L.J. 615, 638-39 (1998). The Lilly court's holding that describing a method for isolating a DNA sequence is not a sufficient basis for claiming the sequence itself is, of course, consistent with the Deuel court's refusal to consider methods as prior art for claims to DNA sequences. Given the Federal Circuit's strict application of the written description requirement in Lilly, it is unlikely that EST patent applications that seek to claim the full DNA sequence of which the EST is a part, see supra note 150 and accompanying text, will be accepted by the Federal Circuit, because it is unlikely that the description of the full DNA sequence will be ade- 
Thus, with respect to basic research that historically has not been subject to property rights claims, both statutory and case law have moved in the direction of significantly expanded property rights. This movement has largely been the result of explicit legislative efforts-specifically, technology transfer legislation and the legislation creating the Federal Circuit. ${ }^{177}$ The next section discusses the effect that these actions in favor of expanded property rights have had on scientific norms.

\section{Norm Change: The Effect of Legal Change}

The expansion of property rights in research was initially met with loud outcries from the scientific community. Critics extolled the virtues of traditional scientific norms and argued that the intrusion of property rights would thwart the success of scientific research by inhibiting further work in areas that had been removed from the communal domain. ${ }^{178}$ As might be predicted by law-and-norms theory, however, universities and individual researchers soon began to respond to the financial incentives of Bayh-Dole by rejecting communalism and increasing efforts to seek patents. ${ }^{179}$ In some circumstances, universities even pressured recalcitrant faculty members to seek patents. ${ }^{180}$ As a consequence, in the period from 1980 to 1992, the number of patents granted per year to universities increased from fewer than 250 to almost $2,700{ }^{181}$ The pattern of norm breakdown also conformed to the predictions of law-and-norms theory: in particular, once a critical mass of norm violators was reached, rapid norm breakdown en-

quate or even available at all. However, even if EST patents are given a relatively narrow scope, owners of such patents will still have an inefficient level of control over future research. See infra notes 254-69 and accompanying text.

177 Notably, with respect to Federal Circuit case law, there is little reason to believe that the court has gone beyond the bounds of Congress' technology policy. See Dreyfuss, supra note 139, at 27-28.

${ }_{178}$ See, e.g., Commercialization of Academic Biomedical Research: Hearing Before the Subcomm. on Investigations and Oversight and the Subcomm. on Science, Research, and Technology of the House Comm. on Science and Technology, 97th Cong. 62-63 (1981) (statement of Dr. Jonathan King).

179 Patents undermine communalism in two different ways. First, and most obviously, they do so because communalism explicitly disavows property rights. See supra notes $68-70$ and accompanying text. Patents also undermine communalism because they can lead to a significant increase in secrecy. Researchers are likely to delay publication (or submission for publication) until a patent application has been filed. See infra notes 187-89 and accompanying text.

180 See P. Lachs, University Patent Policy, 10 J.C. \& U.L. 263 (1984). Most universities now have faculty, students, and others who use their research facilities sign agreements under which the researcher agrees to disclose all inventions to the university and assign to the university all patent rights. See, eg., Massachusetts Institute of Technology Inventions and Proprietary Information Agreement (on file with author).

181 See Patent Issues in Federally Funded Research: Hearings Before the Senate Judiciary Subcomm. on Patents, Copyrights, and Trademarks, 103rd Cong. 11 (1994) (statement of Birch Bayh). See also Lita Nelsen, Policy and Pragmatism at a University Licensing Office, Presentation at Conference on Biotechnology and the Law: New Perspectives on Public Access and Proprietary Rights (Feb. 20, 1998) [hereinafter Nelsen, New Perspectives] (copy of text on file with author) (discussing increase in numbers of university patents). The percentage increase in number of patents awarded far outpaced the relatively modest increase in university research and development expenditures. See Eisenberg, supra note 90, at 1708 n.186. 
sued. $^{182}$ Moreover, with the legal change and accompanying norm breakdown, the social meaning of a decision by a researcher or academic institution to apply for a patent changed. Where patent acquisition had once been seen as violating the scientific ethos, it came to be seen as a necessary part of any competitive academic institution's research policy and as a means of enhancing national competitiveness generally. ${ }^{183}$ For example, the Massachusetts Institute of Technology (MIT) Technology Licensing Office, which is responsible for seeking and licensing patents on behalf of MIT researchers, explicitly declares in its current mission statement that the office exists to "benefit the public by moving results of MIT research into societal use via technology licensing ...."184

In addition to increasing patenting activity, the legal developments of the 1980s and 1990s have generated a large variety of academic-industrial relationships. Not only does industry now fund a nontrivial percentage of academic research in the life sciences, ${ }^{185}$ but some academic-industrial relationships resemble commercial joint ventures. ${ }^{186}$ Participants in these aca-

182 See supra text accompanying note 53 (discussing idea that when number of norm violators reaches a critical mass, the result can be rapid norm breakdown). While the number of patents granted to universities increased slowly in the period from 1980 to 1985, it then went up almost fourfold in the seven year period between 1985 and 1992. See Nelsen, New Perspectives, supra note 181. In all likelihood, the rapidity of norm change was also influenced by the fact that even those individuals and institutions opposed to patenting did not want to be the only ones left who failed to take advantage of licensing revenues. Notably, although the technology transfer statutes of the 1980 s were not intended specifically to address the commercialization of biotechnology, the statutes' biggest impact, by far, has been in biotechnology. In the University of California system, the majority of the top twenty-five revenue-generating patents are in the area of molecular biology. See William Hoskins, Presentation at Conference on Biotechnology and the Law: New Perspectives on Public Access and Proprietary Rights (Feb. 20,1998 ) (copy of text on file with author). Similarly, $\$ 50$ million of the $\$ 74.7$ million in patent licensing revenues generated by the University of Califomia system comes from the University of California, San Francisco, where research focuses on molecular biology. See id.

183 See Nelsen, New Perspectives, supra note 181.

184 MIT Technology Licensing Office, Mission Statement (visited July 21, 1999) <http:/web.mit.edu/afs/ athena.mitedu/org/t/lo/www/mission.html?.

185 According to one study, industry funds $11.7 \%$ of academic research in the life sciences and about 7\% of university research and development in all scientific fields together. See David Blumenthal et al., Relationships Between Academic Institutions and Industry in the Life Sciences-An Industry Study, 334 NEW ENG. J. MED. 368, 369 (1996).

${ }^{186}$ Consider the following examples. Harvard University and the biotechnology company Genica are currently working together on an eye test for Alzheimer's disease. Under Harvard's agreement with Genica, Genica gets exclusive rights to market the test while Harvard receives royalties on future sales. Johns Hopkins University has joined with Genetics Institute, Inc. (GI) to form MetaMorphix, Inc., a company which will focus on diseases of the nervous system. GI has invested $\$ 3.6$ million for a 58\% share of the company, while Johns Hopkins has contributed nineteen genes for the remaining $42 \%$. Johns Hopkins will receive royalties based on its contribution to a particular product when that product is sold by either GI or Metamorphix. Johns Hopkins is also collaborating with Human Genome Sciences, Inc. (HGS) in researching genes identified by HGS as playing a role in colon cancer. Johns Hopkins has granted HGS an exclusive license to the results of the project in retum for access to the HGS gene sequence database. For these and other examples, see Michael J. Malinowski \& Maureen A. O'Rourke, A False Start?: The Impact of Federal Policy on the Genotechnology Industry, 13 Y ALE J. ON REG. 163, 185-86 (1996). 
demic-industrial relationships often depart quite markedly from traditional research norms. A recent survey of more than 2,100 life science faculty in the fifty top research universities revealed that participation in an academicindustry research relationship (or in the commercialization of research) was associated with a delay in publication of greater than six months. ${ }^{187}$ Moreover, although publication delays sometimes occurred in order to protect a scientific lead in publication-a result allowed by traditional research normsthey were more likely to be motivated by a desire to address intellectual property concerns. ${ }^{188}$ Other empirical studies have shown that corporate sponsors of research often require that research be kept secret for a period of time longer than that necessary for the filing of a patent application. ${ }^{189}$

Commercial involvement in academic research has also undermined norms governing the sharing of research materials and tools. ${ }^{190}$ Companies that license these materials and tools to academic researchers often force researchers to sign materials transfer agreements (MTAs) that tightly restrict the researchers' use of these materials. For example, many MTAs require researchers to assign or license intellectual property rights to discoveries made in the course of using the research tools. ${ }^{91}$ Others prohibit sharing tools with other researchers or sending them to other institutions. ${ }^{192}$

187 See David Blumenthal et al., Withholding Research Results in Academic Life Sciences: Evidence From a National Survey of Faculty, 277-92 JAMA 1224 (1997). A total of 140 respondents (19.8\% of those surveyed) reported that they had delayed publication of their research results for more than six months in the last three years. One hundred and eighty-one respondents, or $8.9 \%$ of those surveyed, reported refusing to share results with other university scientists in the last three years. Id. Two variables that were significantly associated with delays in publication were participation in an academicindustry relationship and engagement in the commercialization of research; involvement in the commercialization of research was also significantly associated with the refusal to share such results. Id. The survey also found that investigators in the field of genetics were more likely to engage in datawithholding behavior than investigators in other life science fields. Id. at 1227.

188 See id. at 1226.

189 See Blumenthal, supra note 185 , at 371 . Fifty-six percent of corporate sponsors said that research results were sometimes kept confidential longer than the time required to file a patent. Id. Moreover, the NIH has indicated that thirty to sixty days is a "reasonable" period of time to delay the release of information pending the filing of a patent application. See National Institutes of Health, Developing Sponsored Research Agreements: Considerations for Recipients of NHH Research Grants and Contracts, 59 Fed. Reg. 55,674-55,678 (1994). Yet, 58\% of companies said that they typically require academic investigators to keep research confidential for more than six months. Id.

190 The definition of the term "research tool" merits a brief discussion. The research tools about which scientists are most concemed are relatively upstream discoveries such as ESTs, SNPs, receptors, cell lines, and animal models that will be used in research directed towards the identification of new therapeutic compounds. See Report of the NIH Working Group on Research Tools, at 4 (visited September 14, 1999) <http:/www.nih.gov/news/researchtools/index.htm> [hereinafter NIH Working Group Report]. As discussed above, see supra notes 149-55 and accompanying text, many biotechnology firms' business plans focus on seeking intellectual property rights in these research tools.

191 NIH Working Group Report, supra note 190, at 7-8.

192 Id. at 9. For example, the DuPont Corporation allegedly placed substantial restrictions on academic researchers who receive licenses to use research tools patented by DuPont, most notably the creloxP mice (mice with one specific gene deleted). See Heller \& Eisenberg, supra note 1, at 699. Re- 
This norm change has, however, been tempered by some attention to the traditional values of research science. Major research universities have sought to maintain certain aspects of traditional scientific norms even while embracing the development-promoting aspects of property rights. For example, the approach used by MTT attempts to maintain the free flow of information required by communalism even while it recognizes the concern that, in certain situations, product development will require exclusivity. Under MIT's policy, if intellectual property protection is needed to induce commercial development of research, that factor weighs in favor of patenting. Thus, for example, MIT supports the patenting of fully characterized genes if the project was "specifically designed or funded to identify specific genes or functions" and there is an exclusive licensee committed to rapid and effective development of the gene. On the other hand, if the research in question is quite far removed from specific commercial development, there is a presumption against patenting. ${ }^{193}$ For example, MIT is reluctant to allow patenting of ESTs of unknown function. MIT does not view proprietary rights on such ESTs as a means of promoting the development of useful products. For similar reasons, MIT takes a cautious approach towards patents on cell receptors and on SNPs. Although MIT has, on occasion, patented receptors, there is a presumption against patenting. In addition, patents on receptors are licensed nonexclusively. As for SNPs, MIT will patent them only in those narrow circumstances where it can be shown that proprietary rights are necessary for development. ${ }^{194}$

MIT has also disavowed patenting for purely strategic reasons. For example, it does not patent as a "defensive" strategy against research competitors; in other words, it does not seek patents simply as a means of thwarting others from patenting. ${ }^{195}$ Similarly, MIT does not file patents in order simply to "lie in wait," hoping that after the patent issues, it can find inadvertent infringers that it can then sue for royalties. ${ }^{196}$

The technology transfer policies at Harvard University and Stanford University reflect a similarly restrained attitude toward the patenting of basic molecular biology research. For example, neither university files patent applications on ESTs. ${ }^{197}$ Moreover, both universities are reluctant to file

cently, however, Dupont responded to pressure from the NIH and agreed to allow NIH researchers freely to disseminate cre-loxP materials to other non-commercial researchers. See NIH News Release, NIH, Jackson Laboratory, and DuPont Pharmaceuticals Sign Cre-Lox Technology Use Agreements (August 21, 1998) < http://www.nih.gov/news/pr/augh98/od-21.htm>.

193 See Nelsen, New Perspectives, supra note 181.

194 Policy Statement by Lita Nelsen, Director, Technical Licensing Office, MIT, June 2, 1998 (on file with author). For example, one situation in which proprietary rights might be useful would be if the clinical function of the SNP had been clearly identified. A SNP of known function is more ripe for commercial development than a SNP of unknown function.

195 See Nelsen, New Perspectives, supra note 181.

196 Nelsen, supra note 194.

197 See Policy Statement by Katherine Ku, Director, Office of Technology Licensing, Stanford University (July 16, 1998) (on file with author); Policy Statement by Joyce Brinton, Director of the Office 
patent applications on SNPs. ${ }^{198}$ At Stanford, the view is that SNPs are likely to be useful to many developers, and therefore SNP patents should be filed only in the unusual circumstance where an exclusive licensee would bring "real value added."199

University researchers have also engaged in more systematic efforts to preserve public domain-oriented values. In February 1996, a group of publicly-funded genome researchers passed a resolution stating that "all human genomic DNA sequence information generated by centers funded for largescale human sequencing should be freely available and in the public domain in order to encourage research and development."200 Similarly, in 1995, more than one hundred universities formulated the Uniform Biological Materials Transfer Agreement (UBMTA) to govern transfers of biological material among universities. ${ }^{201}$ (By contrast, nothing came of efforts to engage academic institutions and private companies in a collaborative effort to set up a second model MTA that could be used for interactions with private companies.) $)^{202}$ Under the UBMTA, the academic recipient of biological materials may use the materials for non-commercial teaching and research purposes without having to negotiate a licensing agreement. ${ }^{203}$ Signatory universities are supposed to use the UBMTA, or a simplified or modified version thereof, for their materials transfers. ${ }^{204}$

of Technology and Trademark Licensing, Harvard University (July 22, 1998) (on file with author). Similarly, Washington University, one of the largest recipients of federal genomic funding, does not file patent applications on ESTs. Interview with Andrew Neighbour, Associate Vice Chancellor for Technology Management, Washington University (September 27, 1999).

198 Policy Statement by Katherine Ku, supra note 197.

199 Id. Notably, these policies regarding patenting apply irrespective of whether the research in question is sponsored by public money or by industry. In addition, many universities require that, even in industry-sponsored research, ownership of intellectual property reside with the university. See, e.g., Harvard University, Licensing Program: Objectives and Procedures (on file with author) (noting that, in general, industry-sponsored research agreements will provide for ownership of intellectual property to reside with university, subject to a royalty-free license for the sponsor's internal research use); MIT, Guide to the Ownership, Distribution, and Commercial Development of MIT Technology, § 2.1.1 (on file with author).

${ }^{200}$ See Eliot Marshall, Genome Researchers Take the Pledge: Data Sharing, 272 SCIENCE 477, 478 (1996). In fact, under this resolution, known as the Bermuda Agreement, researchers submit DNA data to a public database every 24 hours. Nicholas Wade, Talk of Collaboration on Decoding of the Genome, N.Y. TIMES, Nov. 14, 1999, at 18.

201 See Eliot Marshall, Need a Reagent? Just Sign Here . . . , 278 SCIENCE 212, 213 (1997). As of January 22, 1998, 126 institutions had signed the Master Agreement. See The Uniform Biological Material Transfer Agreement: Signatory Institutions (visited January 28, 1999) <http:/hhse.cs.rice.edu/autm/ubmta/listhtml>.

202 See Marshall, supra note 201, at 213.

203 See Uniform Biological Material Transfer Agreement (visited January 28, 1999) >http:/nhse.cs.rice.edw autm/ubmta/umbta-master.html>.

204 The simplified version of the UMBTA, used by some universities, also exempts from licensing requirements biological materials that will be used for non-commercial purposes. See Simple Letter Agreement for Transfer of Non-Proprietary Biological Material (visited January 2, 1999) <http://nhse.cs.rice.edu/autm/ubmta/ubmta-simple.html>. So do many of the modified agreements. See, e.g., Stanford Agreement for Use of Certain Biological Materials, at 2 (on file with author). It should be 
Residual norms of academic research may even have had some influence on the conduct of industry actors. Consider the example of Celera, a collaboration between the Institute for Genomic Research (TIGR), a private, non-profit genetics laboratory, and Perkin-Elmer, a manufacturer of DNA-sequencing instruments. The aim of the collaborative effort (which is being directed by Dr. Craig Venter, head of TIGR, ${ }^{205}$ and Michael Hunkapiller, president of Perkin-Elmer's applied biosystems division) is to sequence the human genome in three years using a "shotgun" approach different from that of the NIH-sponsored effort. ${ }^{206}$ According to the principals, Celera will refrain from claiming certain intellectual property rights in the genome. In particular, it will publicly release all "raw" sequence data. ${ }^{207}$ Part of the reason for this may be that the value of intellectual property rights in raw sequence data has been diminished by the public release of such data by federally funded sequencing centers. In addition, the interests of Perkin-Elmer could be well served by having the DNA sequence data disseminated widely; the company apparently believes that such widespread availability will create demand for its sequencing machines. ${ }^{208}$ Nonetheless, it is interesting to note that the policy has been couched in the rhetoric of norms: Dr. Venter has stated that "we feel morally compelled to

noted, however, that adherence to UMBTA principles has not been uniform. See NIH Working Group Report, supra note 190, at 10 (noting that "[w]e have received copies of MTAs sent by universities and nonprofit institutions to researchers in other universities that present just about every type of clause that universities cite as problematic in the MTAs and licenses that they receive from industry ....?). For example, a recent MTA involving mammalian DNA sequences negotiated between Oxford University and the University of California, San Francisco stipulated that Oxford retained the right to preview articles (for the purposes of determining intellectual property rights) before they were submitted for publication. See Marshall, supra note 201, at 212. Similarly, Georgetown University, a signatory to the UMBTA, recently drafted an MTA requiring that it see an advance copy of any proposed publication that made reference to the transferred material. Id. at 213. Legal mechanisms that could be used to encourage greater compliance with the norms embodied in the UMBTA are discussed infra notes 360-65 and accompanying text.

${ }^{205} \mathrm{Dr}$. Venter is the same individual who sought patents on thousands of ESTs when he was at the NIH. See supra note 119 and accompanying text.

206 See, eg., Genetic Warfare, ECONOMIST, May 16, 1998, at 87. Under Celera's approach, the genome is cut into many small fragments, and the fragments are sequenced. The fragments are then ordered by matching the overlaps of the individual fragments. Each of the steps in this process is automated, so the sequencing can run continuously. See id. at 87-88. See also Clive Cookson, Rival Strategies in Race to Unravel Genetic Code, Fn. TimEs, May 26, 1998, at 10; Nicholas Wade, It's a Three-Legged Race to Decipher the Human Genome, N.Y. TMMES, June 23, 1998, at B11. By contrast, under the approach adopted by the NIH effort, each DNA fragment is mapped to its source site on the chromosome and sequenced separately. See Wade, supra, at B11. Recently, there has been some discussion of a possible collaboration between Celera and the public effort. One point of dispute, however, has been the public consortium's insistence on immediate (i.e., within 24 hours) data release. See Wade, supra, note 200 .

207 See Human Genome Project: Hearing Before the Subcomm. on Energy and Environment of the House Comm. on Science, available in WL 323570, at *27 (June 27, 1998) [hereinafter Human Genome Project Hearing] (statement of Dr. Venter).

${ }^{208}$ See Nicholas Wade, Scientist's Plan: Map All DNA Within 3 Years, N.Y. TIMES, May 10, 1998, at A1. 
release th[e] genome sequence to the entire public.... The companies that have proceeded on the basis of secrecy are taking things very much in the wrong direction ...."209 Indeed, according to some industry observers, what Venter is doing is "not a commercial venture . . . . It's really Craig Venter going after the Nobel Prize for sequencing the genome."210

In sum, the post-1980 move towards greater intellectual property rights has clearly had a significant impact on the traditional norms of research science. Perhaps most obviously, the communalism norm has been undermined by the dramatic increases in patenting activity. In addition, both communalism and norms against secrecy have been eroded by delays in publication and restrictions on the sharing of research materials and tools caused by concerns about intellectual property rights. Nonetheless, even in the face of commercialization pressures, many major research universities have drawn the line at claiming property rights in certain basic scientific discoveries, particularly upstream discoveries that may be useful in a variety of different future research paths or for the development of a variety of commercial products.

The remainder of this Article argues that the approach adopted by these universities offers valuable insights into the problem of achieving the proper balance between property rights and the public domain. Part III supports this argument by demonstrating that the highly aggressive patenting of basic research encouraged by post-1980 statutory and case law does not in fact further the economic goal of developing new products, the goal most frequently cited by Congress as a justification for passing new patent legislation. Part IV develops an economic model for balancing property rights and the public domain and argues that the prescriptions of this model are similar to the results yielded by current university patenting norms.

\section{Patenting Basic Science: The Economic ANALysis}

As discussed in Part II, Congress's decision to pass legislation encouraging the patenting of basic research was based on the view that traditional scientific norms, which discouraged patenting, did not further the goal of developing commercial products. ${ }^{211}$ In this Part, I critique this "develop-

209 Human Genome Project Hearing, supra note 207, at *29.

210 John Carey, The Duo Jolting the Gene Business, Bus. WK., May 25, 1998, at 75 (quoting Randal W. Scott, president of Incyte, Inc.). The venture plans to make money by patenting genes that are less frequently expressed and therefore have not been the target of patent applications by companies like Human Genome Sciences that use EST-based approaches to sequencing. In addition, it plans to "package" the raw genomic information in useful ways and then sell this "packaged" information. Genetic Warfare, supra note 206 , at 88. Notably, however, some of the proprietary packaged information will include data on SNPs. Id.

${ }^{211}$ From the perspective of law-and-norms theory, the fact that traditional research norms may have been inefficient in this respect is not surprising. Law-and-norms theory counsels that the norms of a particular group will be efficient only with respect to the goals of that group's members. See supra note 47 and accompanying text. Traditionally, academic research scientists have not aspired to, or been rewarded for, the production of commercial products. 
ment-oriented" justification for patenting, which was advanced in the debate over the Bayh-Dole legislation ${ }^{212}$ and, within the academic literature, has been advanced by Edmund Kitch and other property rights theorists. ${ }^{213}$ I discuss the merits and limitations of these arguments at length in Part III.B. I first discuss briefly, however, why traditional economic analysis counsels against aggressive patenting of basic science.

\section{A. Traditional Economic Considerations: A Focus on Invention}

The traditional economic justification for granting patent rights (as well as copyright) is that the conferring of such rights addresses the collective action and public good problems discussed above ${ }^{214}$ by providing individuals with incentives to devote time, energy, and resources to inventing or creating products that will have value to society as a whole. ${ }^{215}$ Without

212 See supra notes $108-13$ and accompanying text.

213 See supra Part III.B (outlining these arguments).

214 See supra text accompanying note 29.

215 This particular justification is unambiguously at the heart of the intellectual property grant. The Constitution states that intellectual property rights are granted for "limited Times" in order "to promote the Progress of Science and useful Arts." U.S. ConST., art. I, § 8, cl. 8. In both patent law and copyright, the Supreme Court has repeatedly invoked this instrumental justification. See, e.g., Fogerty v. Fantasy, Inc., 510 U.S. 517, 526 (1994) (noting that intellectual property rights are "intended to motivate the creative activity of authors and inventors by the provision of a special reward ...." (quoting Sony Corp. v. Universal City Studios, Inc., 464 U.S. 417, 429 (1984)); Graham v. John Deere Co., 383 U.S. 1, 9 (1966) ("The patent monopoly was not designed to secure to the inventor his natural right in his discoveries. Rather, it was a reward, an inducement, to bring forth new knowledge."); Mazer v. Stein, 347 U.S. 201, 219 (1954) ("The economic philosophy behind the clause empowering Congress to grant patents and copyrights is the conviction that encouragement of individual effort by personal gain is the best way to advance public welfare ....'). Indeed, in the Graham case, the Supreme Court quoted Thomas Jefferson as arguing that inventions "cannot, in nature, be a subject of property. Society may give an exclusive right to the profits arising from them, as an encouragement to men to pursue ideas which may produce utility, but this may or may not be done, according to the will and convenience of the society, without claim or complaint from any body." Graham, 383 U.S. at 9 n.2 (quoting Letter from Thomas Jefferson to Isaac McPherson (Aug. 13, 1813), in 6 THE WRITINGS OF THOMAS JEFFERSON 175, 180-81 (H.A. Washington ed., 1854)). Numerous commentators have also discussed this instrumental rationale for intellectual property rights. See, e.g., FREDERIC M. SCHERER, INDUSTRAL MARKET STRUCTURE AND ECONOMIC PERFORMANCE 440 (2d ed. 1980); SUBCOMM. ON PATENTS, TRADEMARKS, AND COPYRIGHTS OF THE SENATE COMM. ON THE JUDICIARY, 85TH CONG., AN ECONOMIC REVIEW OF THE PATENT SYSTEM 21, 33-35 (GPO, 1958) (review written by Fritz Machlup) [hereinafter PATENT SYSTEM REVIEW]; Kenneth J. Arrow, Economic Welfare and the Allocation of Resources for Invention, in THE RATE AND DIRECTION OF INVENTIVE ACTIVITY 609, 617 (National Bureau of Economic Research, 1962) (discussing incentives created by patent system).

By contrast, development-oriented arguments (discussed further infra Part III.B) have less support in the constitutional text or in Supreme Court jurisprudence. Similarly, arguments for non-utilitarian approaches to intellectual property do not have clear textual support. For discussions of these arguments, see, for example, Wendy J. Gordon, A Property Right in Self-Expression: Equality and Individualism in the Natural Law of Intellectual Property, 102 YALE L.J. 1533, 1540-44 (1993) (invoking Lockean natural rights and labor theory as a justification for individual intellectual property rights); Neil Netanel, Copyright Alienability Restrictions and the Enhancement of Author Autonomy: A Normative Evaluation, 24 RUTGERS L.J. 347 (1993) (discussing intellectual property rights in the context of property as 
such incentives, inventions or creations with potentially great social bene$\mathrm{fit}^{216}$ might be delayed or might never come about at all..$^{21}$

The traditional economic defense of patent rights also holds that, once an invention has been produced, such rights maximize the social benefit that can be derived from the invention by creating value that survives disclosure of the invention to the general public. ${ }^{218}$ Arguably, in the absence of patent protection and the value it provides, inventors would keep their inventions secret. This secrecy could be achieved in one of two ways. Most obviously, the information holder could succeed in keeping the information actually secret. Alternatively, the holder could take reasonable precautions to prevent the information from becoming generally known but release it selectively to business customers under confidentiality agreements. In the latter situation, the information would be a trade secret, and the holder could sue those who improperly obtained the information by circumventing the reasonable precautions. $^{219}$ In either case, secrecy could, for an indefinite period of time, prevent the public from gaining the full benefit of new knowledge.

The traditional defense of patent rights also recognizes, however, that these benefits can be outweighed by the many costs associated with the patent grant. For example, although patent grants may stimulate the production of new inventions, this benefit is reduced by the fact that these grants limit the full productive use of these inventions. ${ }^{220}$ On the traditional view,

"personhood"). For arguments that the natural rights approach, combined with a romantic view of the individual author or inventor, has led to overprotection of intellectual property, see JAMES BOYLE, SHAMANS, SOFTWARE, AND SPLEENS: LAW AND THE CONSTRUCTION OF THE INFORMATION SOCIETY (1996); Keith Aoki, Authors, Inventors and Trademark Owners: Private Intellectual Property and the Public Domain, 18 ColUM.-VLA J.L. \& ARTS 1 (1993-1994).

216 Economists have frequently emphasized the extemalities produced by investment in research. For example, one study found that the median social rate of retum from industrial innovations in various industries was $56 \%$; by contrast, the median private rate of return on these innovations was only $25 \%$. Edwin Mansfield, Contributions of New Technology to the Economy, in TECHNOLOGY, R \& D, supra note 1 , at 116.

217 Mark Grady and Jay Alexander have argued that the traditional approach to patenting can be further subdivided into two versions. The "weaker" version asserts generally that a purpose of the patent law is to stimulate invention. The "stronger" version asserts more specifically that patents should only be granted where the invention would not have emerged but for the inducement of the patent. See Mark F. Grady \& Jay I. Alexander, Patent Law and Rent Dissipation, 78 VA. L. REv. 305, 312-13 (1992). See also A. Samuel Oddi, Un-Unified Economic Theories of Patents-the Not-Quite-Holy Grail, 71 NOTRE DAME L. REv. 267, 277-81 (1996) (discussing, and arguing in favor of, "patentinduced" theory). Because only the "stronger" version of the theory provides a mechanism for determining whether a given invention (or set of inventions) should be patentable, this Article focuses on the "stronger" version.

${ }^{218}$ See PATENT SYSTEM REVIEW, supra note 215 , at 21. A parallel argument about disclosure can be made regarding creative works and copyright.

219 See generally Uniform Trade Secrets Act §§ 1-3 (amended 1985); RESTATEMENT OF TORTS $§ 757$ cmt. b (1939).

220 See, e.g., SCHERER, supra note 215, at 442 ("Ideally, the life of a patent should be no longer than it needs to be to encourage the optimal amount of invention, so that monopolistic restrictions are terminated as soon as possible."). 
productive uses that may be limited include both direct use of the invention as an end product and use of the invention in further improvement and development. ${ }^{221}$ These uses may be inhibited if the patent holder can use its position to charge a supracompetitive price or if there are significant transaction costs associated with licensing. ${ }^{222}$ For these reasons, the alternative of stimulating invention through public financing has often been debated by traditional economic theorists. ${ }^{223}$ Indeed, public patronage has been one prominent means that western democratic societies have used to promote scientific inquiry. ${ }^{224}$ In addition, the traditional economic view recognizes that while patents promote disclosure, the level of disclosure achieved with patent rights is not necessarily significantly greater than that which would occur absent patent rights. ${ }^{225}$ Although inventors might, absent patent rights, attempt to keep their inventions secret, such attempts at secrecy would not protect against the possibility of someone else coming up with the same invention. ${ }^{226}$ In addition, they would not protect the "know-how" necessary to make the product when such "know-how" became readily discernible (or could be determined through reverse engineering) as a result of placing the product in the stream of commerce. ${ }^{227}$ Indeed, those inventions on which patents are sought may be precisely those which the inventors fear will be difficult to protect through secrecy. ${ }^{228}$

The limitations of the patenting system are particularly evident in the context of many basic molecular biology inventions that are the focus of

\footnotetext{
221 See id. at 450-53. See also PATENT SYSTEM REVIEW, supra note 215, at 55, 64; Paul David, Intellectual Property Institutions and the Panda's Thumb: Patents, Copyrights, and Trade Secrets in Economic Theory and History, in NATIONAL RESEARCH COUNCIL, GLOBAL DIMENSIONS OF INTELLECTUAL PROPERTY RIGHTS IN SCIENCE AND TECHNOLOGY 19, 34 (Mitchel B. Wallerstein et al. eds., 1993) (noting restrictions on invention and innovation resulting from patent grant).

222 See SCHERER, supra note 215 , at 450-53.

223 Another drawback of the patent system noted by traditional theorists is the possibility of inefficient "races" to secure patents. Races will occur, and will be inefficient, if the private value of being the first to invent a particular product or process exceeds the benefit to society of having a slightly earlier discovery date. See David, supra note 221, at 33. Races may also be inefficient because of unnecessary duplication of research and development expenditures. See Kenneth W. Dam, The Economic Underpinnings of Patent Law, 23 J. LEGAL STUD. 247, 251-52 (1994); but see infra note 242 and accompanying text (arguing that, under certain circumstances, ostensibly duplicative research expenditures may not be inefficient). The problem of races is created, however, by any incentive system in which the entire reward goes to the first inventor. Like the patent system, the incentive scheme of academic research rewards the first inventor and may thus create inefficient races. See David, supra note 221, at 33. For further discussion of inefficient patent races, see infra note 242.

224 See David, supra note 221, at 27.

225 See PATENT SYSTEM REVIEW, supra note 215, at 32-33, 53, 76; SCHERER, supra note 215, at 441.

226 See PATENT SYSTEM REVIEW, supra note 215, at 33, 76; Eisenberg, supra note 75, at 1029.

227 See, e.g., Pamela Samuelson et al., A Manifesto Concerning the Legal Protection of Computer Programs, 94 COLUM. L. REv. 2308, 2340-43 (1994).

228 See PATENT SYSTEM REVIEW, supra note 215 , at 32, 53, 76. Moreover, in the U.S. system, disclosure through the patent process is often delayed. Disclosure does not have to occur until affer the patent issues, which is often years after the filing of the patent application.
} 
current efforts to secure patent rights. Because many of these inventions can be identified with a small amount of effort, ${ }^{229}$ it is not clear that the incentive of a patent grant is necessary. Moreover, as discussed in Part III.B below, the transaction cost problems associated with licensing these inventions, particularly for development and improvement, are significant. Finally, secrecy is likely to prove particularly ineffective in the context of these early-stage or upstream inventions: because they can be identified easily, the likelihood of independent invention is high. ${ }^{23}$

The social costs of patenting identified by the traditional view assume particular importance when one considers the extent to which inventive basic research has historically been produced and disclosed without a patent system. In particular, the research norms of invention and communalism have respectively stimulated scientists to research and to contribute their ideas and material into a common pool. Well before Bayh-Dole allowed universities to seek patent rights on their inventions, American research universities were publishing pioneering research. ${ }^{231}$ To the extent that norms of invention and communalism are eroded by pressures to secure property rights, we lose a relatively cost-free mechanism for enriching the store of knowledge.

To be sure, the invention norm is not, by itself, sufficient to produce invention. Academic researchers still need to be subsidized for the costs of their labor and research equipment. However, the invention norm reduces the cost of the labor subsidy. Moreover, it bears mention that the type of

229 See, eg., Eliot Marshall, A Showdown over Gene Fragments, 266 SCIENCE 208, 210 (quoting statement by National Center for Human Genome Research scientist that EST identification "isn't brain surgery"). See also supra text accompanying note 176 (noting that biotechnological methods for obtaining ESTs have been well known in the literature since 1991).

${ }^{230}$ A few companies, most notably Human Genome Sciences, Inc. (HGS) and Incyte Pharmaceuticals, have, however, been able to charge substantial licensing fees for access to their proprietary databases of genomic information. The primary licensees have been pharmaceutical companies focused on end-product development. See Eisenberg, supra note 1, at 566-70. The possibility that companies may react to restrictions on patent rights by securing property rights through contract is not, however, an argument in favor of patenting. Property rights through contract do not constrain the work of independent researchers. Moreoever, a patent application is by no means a guarantee of disclosure. Before they are certain that a patent will issue-a process that can take many years, particularly in the context of many biotechnology applications, see Marshall, supra note 149 (noting that given the number of patent applications on DNA sequences that have been filed by private companies that specialize in sequencing DNA, it may take the PTO more than a century to complete review of the applications)-potential patentees may be reluctant to disclose their research. By refraining from disclosure even after they have filed a patent application, potential patentees leave open the option of protecting their research as a secret in the event a patent does not issue. Indeed, commercial biotechnology companies often opt for post-filing secrecy. For example, although Incyte Pharmaceuticals and Human Genome Sciences, Inc. (HGS) have sought patents on upstream genomic information such as ESTs, see supra note 166 and accompanying text, they also maintain privately held databases containing this information. See Eisenberg, supra note 1 , at 559 .

231 See generally Kenneth Goodman, Intellectual Property and Control, ACAD. MED., Sept. 1993, at $\mathbf{S 8 8 .}$ 
NORTHWESTERN UNIVERSITYLAW REVIEW

research that emerges as a result of patent incentives may be quite different from the research that would emerge in the absence of such incentives. ${ }^{232}$ In particular, Rebecca Eisenberg (among others) has persuasively argued that research that yields patent rights may be less socially valuable in the long term than more fundamental projects for which patent rights are not granted and for which the dominant incentive is academic recognition. ${ }^{233}$

Thus, the traditional economic arguments do not favor patenting basic research to any significant extent, let alone to the extent claimed by proponents of the post-1980 changes in intellectual property law. Not surprisingly, then, the primary arguments for allowing such patenting have not been traditional invention and disclosure arguments. Rather, the claim has been that strong property rights in invention are like strong property rights in land: they serve to ensure efficient development and commercialization of valuable property. In Part II.B, I discuss this development-oriented approach.

\section{B. Development-Oriented Perspectives}

In contrast with traditional economic theorists, development-oriented theorists do not view patent rights as a narrowly tailored incentive for invention. Rather, they argue that patent rights should be granted early on in the inventive process and should be very broad, so as to provide a hedge against competition and losses that could be incurred later if another company attempted to develop and commercialize the same invention. In other words, a development-oriented perspective focuses less on the period of early invention than on the period when the company is in the process of turning a basic invention into a marketable product. As discussed in Part II, development-oriented arguments led Congress to adopt the Bayh-Dole Act and appear to have been a factor behind the Federal Circuit's liberalization of the standards for patentability.

The development-oriented approach finds its most forceful academic exposition in the work of Edmund Kitch. ${ }^{234}$ Under Kitch's theory, intellec-

\footnotetext{
232 See Goldman, supra note 15, at 79-80 (noting that this is one reason that Westem societies have funded research through a system of public patronage).

233 See Eisenberg, supra note 90, at 1714-15. Notably, because public subsidies for research are generally distributed through a peer-review process, satisfying the invention norm is central not only to career advancement generally but also to the specific goal of securing grants.

${ }^{234}$ Kitch's argument has both a normative and a descriptive component. He argues not only that the legal system should grant broad patent rights over basic invention that is quite far from marketability, but also that it does grant such rights. See Edmund Kitch, Nature and Function of the Patent System, 20 J. L. \& ECON. 265, 267-71 (1977). I will focus here on the normative validity of Kitch's claims; for discussion of their descriptive validity, see Eisenberg, supra note 75, 1042-43 nn.108, 114, 117, and sources cited therein. Kitch's argument bears a family resemblance to some earlier arguments in favor of strong patent rights. See, e.g., JOSEPH A. SCHUMPETER, CAPITALISM, SOCIALISM, AND DEMOCRACY 83-88 (1950) (arguing that investment in development necessitated the hedge against competition provided by monopoly rights and that broad monopoly rights in invention could therefore promote the development of invention more effectively than competition). To the extent Schumpeter was arguing that
} 
tual property rights are granted in order to induce socially useful investment in developing the technological "prospects" ${ }^{\text {"235 }}$ that inventions represent. According to Kitch, absent patent protection of upstream invention, no one will invest in development for fear that "the fruits of the investment will produce unpatentable information appropriable by competitors. ${ }^{236}$ I critique the applicability of this approach to basic research, first, by describing how the benefits of granting intellectual property rights in research are significantly diminished by the losses in creativity and high transaction costs that such grants generate and, second, by explaining why norm-like mechanisms for addressing transaction costs are unlikely to be successful.

1. Applying the Development-Oriented Perspective to Research. In the specific context of biotechnology, the argument that a patent monopoly provides a hedge against competition and uncertainty in the development process has some merit. The research involved in going from a basic invention with research potential (e.g., a gene fragment/EST, SNP, or receptor) to a therapy that is ready for clinical testing can be very lengthy and expensive. $^{237}$ In order to finance this development, biotechnology compa-

actual monopoly power in the market (as contrasted with monopoly rights in a certain invention) promotes development, his argument is widely disputed; many economists are suspicious of the development capacity of monopolists with actual market power. See, e.g., Arrow, supra note 215, at 619-22.

235 Kitch's use of the term "prospects" is based on an analogy he draws between patents and mining claims in the American West. Kitch argues that like exclusive claims to prospective mineral rights on a plot of land, patents are granted not on fully commercialized inventions but on commercial "prospects." See Kitch, supra note 234, at 266, 271-75.

236 Kitch, supra note 234, at 276. See also David, supra note 221, at 40-41 (arguing that patent grant allows the patent holder to "internalize" the benefits of the development process). Kitch's work identifies intellectual property quite closely with a particular theory of tangible property rights. Indeed, Kitch observes that his arguments are intended to "reintegrate the patent institution with the general theory of property rights." Kitch, supra note 234, at 275. As Harold Demsetz has argued, one reason tangible property rights are given is to induce socially useful investment in the property. See, eg., Harold Demsetz, Toward a Theory of Property Rights, 57 AM. ECON. REv. 347 (1967). Absent property rights, individuals will be reluctant to invest, fearing that others may appropriate the value of the investment. Far from investment, the likely result will be overconsumption of the good in question, a "tragedy of the commons." Although the issue of promoting investment arises in both tangible and intellectual property, the tragedy of the commons problem is not readily apparent in the context of intellectual property. To the contrary, commentators have long noted that because intellectual property can be used by an unlimited number of people, it is not subject to concerns regarding scarcity and depletion. See, e.g., Arrow, supra note 215 . Kitch does suggest, however, that the resources available to develop intellectual property are scarce: he argues that the patent holder should coordinate the use of these resources so that duplicative investment is avoided. Kitch, supra note 234, at 276. For further discussion of this argument, see infra notes $241-42$ and accompanying text.

237 See generally TEITELMAN, supra note 61, at 196-98; Geoffrey Carr, Survey: The Pharmaceutical Industry, ECONOMST, Feb. 21, 1998, at 5-13. Even after a therapy is ready for clinical testing, the FDA-mandated testing process averages nine or ten years and costs about $\$ 100$ million. See Carr, supra, at 4. The long and costly clinical testing process does not, however, argue in favor of patenting basic research. The investigational therapy being tested clinically is almost always the subject of a patent. Indeed, it could be argued that the incentive of a patent at the clinical testing stage should be sufficient for companies to invest in development of basic research, and that there is consequently no need to al- 


\section{NORTHWESTERN UNIVERSITY LAW REVIEW}

nies must have either sales revenue or capital-raising ability. Few such companies have sales revenue; ${ }^{238}$ moreover, without a patent portfolio, they often have serious difficulty raising capital for development. ${ }^{239}$

These increased incentives to develop have to be balanced, however, against the reduced creativity in use of the invention that is likely to result from having a single rightsholder conducting development. Any single rightsholder will probably be able to see only some of the potential applications of the invention. ${ }^{240}$ The development-oriented theorists response to this argument appears to be that because all potential users and developers of the invention will identify themselves and seek licenses from the rightsholder, many different perspectives on development will be explored. $^{241}$ Indeed, development-oriented theorists argue that with a single rightsholder these different development avenues will be explored in the most efficient manner: the rightsholder can "coordinate the search for technological and market enhancement of the patent's value so that duplicative investments are not made and so that information is exchanged among the searchers. ${ }^{, 242}$

low patents on the basic research itself. Although this argument against patenting basic research may be valid outside biotechnology, it has less force in biotechnology, where the development process is exceedingly lengthy and expensive. It is useful to contrast biotechnology with the other area of high technology where patent protection is heavily debated-computer software. While commentators have debated the merits of patent protection for computer software, they agree that the computer industry has been able to develop quite rapidly without the benefit of clear patent protection. Compare Samuelson et al., supra note 227, at 2343-48 (arguing against patent protection) with Oddi, supra note 217 (arguing for patent protection). By contrast, in the biotechnology area, there is general agreement that some patent protection has been, and is, necessary for development. The disputes arise over how early in the development process such patent protection should be accorded.

${ }^{238}$ Malinowski \& O'Rourke, supra note 186, at 178.

239 See Andrew Pollack, Weed-Out Time in Biotechnology, N.Y. TIMES, Dec. 16, 1998, at C1, C8. In order to move from basic research to a product that is ready for clinical testing, many biotechnology companies have formed alliances with pharmaceutical companies. See Malinowski \& O'Rourke, supra note 186, at 188-89. See also Pollack, supra, at C8. But even large pharmaceutical companies often seek to hedge their risk: they will invest funds in development only if the biotechnology company has patented the basic research and the pharmaceutical company can get an exclusive license on the patent. See id.

240 For a similar argument, see Robert P. Merges \& Richard R. Nelson, On the Complex Economics of Patent Scope, 90 CoLUM. L. REv. 839, 873 (1990). As Merges and Nelson note, empirical evidence suggests that once a firm becomes competent in one avenue of development, it may be difficult for the firm to pay attention to other avenues. See id. (citing RICHARD NELSON AND S. WINTER, AN EVOLUTIONARY THEORY OF ECONOMIC CHANGE (1982)). See also Arrow, supra note 215, at 618 (emphasizing importance of multiple research tracks in situations where the application of the information in question is uncertain).

241 Kitch, supra note 234, at 276. According to Kitch, licensing will be particularly necessary because of the broad scope of the patent claims, which will cover not only the invention itself but subsequent improvements and all future uses. Id. at 268-69.

242 Id. at 276. Mark Grady and Jay Alexander have advanced a theory of patenting that is closely related to the development-oriented thesis in that it aims to reduce purported inefficiencies in the development process. According to Grady and Alexander, broad patents should be granted on inventions that clearly "signal" many different improvements. Grady and Alexander argue that if broad patents on these types of inventions are not granted, many different innovators will engage in inefficient races to de- 
The claim that research coordinated by a single rightsholder is necessary in order to prevent duplication of effort is, however, quite suspect. As an initial matter, if development-oriented theorists believe that patent protection is necessary so that the patent holder can eliminate duplicative investment in development, they should not be terribly concerned (as they are $)^{243}$ about insufficient development absent patent rights. Or, to put the point another way, if incentives to develop are likely to be quite meager absent patent rights, there should be little concern about duplicative investment. Indeed, in the context of upstream invention in biotechnology, the problem is clearly one of insufficient incentives to develop, not duplicative investment. ${ }^{244}$ But even if the problem of duplicative investment were real, ${ }^{245}$ and even if it could be eliminated by coordination, it is by no means clear that coordination would be desirable. Contrary to the claims of the development-oriented theorists, the evidence strongly suggests that coordination by a single rightsholder undermines scientific creativity in both basic and applied research. Below I discuss this evidence in each of these contexts, respectively.

In their arguments for the value of coordination and control, development-oriented theorists tend to focus on applied research-that is, research directed towards the commercialization of basic research. Kitch also asserts, however, that his argument regarding coordination and control could apply equally well to basic research itself, so long as a prospect on which patent rights could be granted were found. ${ }^{246}$ This assertion is an important one for molecular biology research, because some of the inventions on which patents are being sought are so removed from commercial application that further basic research will be necessary to identify fully their potential uses. For example, with respect to an EST that can be used as a probe to obtain a full gene sequence, further research will be necessary to characterize the function of the gene for which the EST is a probe. Such research will be sufficiently far removed from commercial application to be considered basic.

velop, and seek patents on, the various improvements. See generally Mark F. Grady \& Jay I. Alexander, Patent Law and Rent Dissipation, 78 VA. L. REv. 305 (1992). Grady and Alexander diverge from the property rights theorists to the extent that they recognize that inefficient patent races can occur not only at the development stage but also at the initial invention stage. Like the development-oriented theorists, however, Grady and Alexander fail to address the main difficulty with granting property rights early on in the development process-the creativity and transaction costs involved in licensing basic patented inventions for development. For an extended discussion of this problem, see infra notes 247-69 and accompanying text.

${ }^{243}$ See supra notes 235-36 and accompanying text.

244 See supra notes 237-39 and accompanying text.

245 Arguably, the development-oriented approach does not claim that insufficient incentives to develop and duplicative investment exist simultaneously. Rather, the claim may be that insufficient incentives to develop exist in those areas where development is likely to produce unpatentable information. By contrast, duplicative investment occurs only if the development is likely to produce patents.

246 See Kitch, supra note 234, at 288-89. 
NORTHWESTERN UNIVERSITYLAW REVIEW

Contrary to Kitch's theory, however, accounts of basic scientific research suggest that coordination of such research is likely to inhibit creativity and thus progress. As Rebecca Eisenberg has emphasized, these accounts hold that progress in basic science occurs most quickly not when it is coordinated by a single entity (such as a patent holder) but, rather, when different teams of scientists, working independently but with an awareness of each other's efforts, use divergent approaches to the same problem. ${ }^{247}$ Attempts by any individual to control these multiple efforts will reduce the total creative output. ${ }^{248}$ In addition, in many basic research situations, coordination and control may lead to the suppression of socially valuable information. For example, the patent holder may exercise control by refusing to license those who have different theoretical perspectives or, more generally, those who represent a professional threat. ${ }^{249}$ In these situations, the potential social benefits of licensing are high: the prospective licensee is planning to use the licensed information either to dispute the claims of the prior researcher or to compete in developing valuable new inventions. However, because this particular social benefit accrues to a competitor rather than to the patent holder, the patent holder may flatly refuse to license. ${ }^{250}$

These arguments regarding the value of independence apply not only to basic research but also to applied research: critics of scientific "planning" have long argued that both basic and applied research require a large degree of independence. ${ }^{251}$ Independence is particularly necessary because many important new technologies come into existence in relatively embryonic form. For example, in the case of both the transistor and the laser, many re-

247 See Eisenberg, supra note 75, at 1061. See also BARBER, supra note 1, at 237 (discussing the informal organizational schemes by which science progresses). Even if some duplication of effort occurs (because, for example, the practice of pre-publication secrecy, see supra text accompanying note 80, keeps competing teams from being fully aware of one another's work), such duplication is not necessarily wasteful. Multiple independent research results have a much greater likelihood of achieving quick recognition in the universe of science. See Robert K. Merton, Multiple Discoveries as Strategic Research Sites, in SOCIOLOGY OF SCIENCE, supra note 65, at 380. Redundant results also indicate that the result is valid. See id. In addition, ostensibly duplicative research may in fact rely on somewhat different techniques; the different results that emerge from these different techniques are likely to be valuable. See Eisenberg, supra note 75, at 1064-65. Research scientists themselves have traditionally opposed coordination in science. This opposition is reflected in the norm of individualism, which holds that scientists should have freedom to pursue projects of their own choosing. See supra note 75 and accompanying text.

248 See Eisenberg, supra note 75, at 1061.

249 See generally id. at 1057-59.

250 Arguably, if the competing researcher were using the patented invention for strictly philosophical, non-commercial purposes, the so-called "experimental use" defense to patent infringement might apply. However, this exception is extremely narrow and has rarely been used. See infra note 316 and accompanying text.

${ }^{251}$ See Eisenberg, supra note 90, at 2067 n.209. Similarly, some economists have argued that, even in the context of applied research, it may be good strategy to have several alternative approaches to a particular objective run in parallel. See Richard R. Nelson, Introduction to THE RATE AND DIRECTION OF INVENTIVE ACTIVITY 3, 9-10 (National Bureau of Economic Research 1962). 
searchers working independently in different firms were responsible for producing the wide variety of applications that are now available. ${ }^{252}$ Even if independence arguments were not applicable, however, there would be other significant problems with using the development-oriented perspective to regulate applied research. As an initial matter, the historical evidence squarely contradicts the claims of the development-oriented theorists. There appear to be few, if any, cases in which the holder of a technological prospect has used it effectively to coordinate development among a variety of researchers. To the contrary, in many industries-including the electrical lighting, automobile, and aircraft industries-the holder of a broad initial patent either had no interest in licensing it for development purposes or could not conclude satisfactory licensing agreements. ${ }^{253}$

The dearth of historical support for the prescriptions of the development-oriented theorists is unsurprising, given the questionable theoretical assumptions upon which they rely. The most problematic assumption made by the development-oriented theorists is the assumption that licensing agreements will be fairly easy to negotiate. To see why this assumption is wrong, consider the following scenario. A researcher suspects that patented gene fragment/EST information might be relevant to the characterization of a full gene and that this full gene might, in turn, be useful in developing a drug therapy. In this case, even if the drug therapy itself did not ultimately infringe the claims of the original patent (because, for example, the EST patentee was only granted claims to the fragment or the full gene of which it was a part and producing the drug itself did not require using either), the research that led to the drug therapy would use the patented product and would thus be infringing. ${ }^{254}$ Therefore, the follow-on improver would have to negotiate a license with the patent holder.

Bargaining between the patent holder and improver would face a variety of obstacles. First, there would be very substantial difficulties in valuation. It is by no means clear how one goes about valuing an EST of unknown function, let alone uncertain but potentially highly lucrative research using that EST. Disagreement about the value of the patented invention relative to the value of the research project might make it very difficult for the parties to agree on the terms for a license. ${ }^{255}$ This disagreement might well be exacerbated by cognitive biases that could lead the EST patent owner to overvalue its asset. In particular, the owner might overestimate

\footnotetext{
252 Richand Nelson \& Paul Romer, Science, Economic Growth, and Public Policy, in TECHNOLOGY, $R \& D, A N D$ THE ECONOMY, supra note 1 , at 65.

${ }_{253}$ See Merges \& Nelson, supra note 240 , at $885-91$.

254 As discussed below, see infra note 316 and accompanying text, the use of the EST for research that has commercial purposes is unlikely to fall within the judicially created "experimental use" exemption to patent infringement.

255 See Mark Lemley, The Economics of Improvement in Intellectual Property Law, 75 TEx. L. REV. 989, 1056 (1997) ("Rational Coasean bargaining assumes perfect information, a characteristic strikingly absent from negotiations involving intellectual property.").
} 


\section{NORTHWESTERN UNIVERSITY LAW REVIEW}

the possibility that the EST would lead to the finding of a valuable drug therapy and then negotiate based on this irrational estimation. ${ }^{256}$

Negotiation would also be hampered by Arrow's information paradox: it might be impossible for the subsequent researcher to get a license ex ante without disclosing to the patent holder valuable information about its own research plans. But because this research plan would not be protectable as intellectual property, the competitor might fear that the patent holder would appropriate the information for its own use, with no compensating benefit to the competitor. ${ }^{257}$ Even if these difficulties did not lead to bargaining breakdown, they would create transaction costs that reduced the cooperative surplus to be gained from a license and would thus deter at least some inventors and improvers from negotiating in the first instance. ${ }^{258}$

Transaction costs would be compounded by the likelihood that the would-be follow-on improver would likely have to negotiate licenses not simply with one owner of basic research but with many such owners. For example, in order to develop a commercial treatment for a genetic disease (particularly a polygenic disease), it may be necessary to have access to a large number of ESTs and SNPs, each conceivably patented by a different entity. ${ }^{259}$ Similarly, in order to screen potential pharmaceutical products for therapeutic effects and side-effects at the pre-clinical testing stage, it may be very useful to have access to a large number of different receptors, each potentially controlled by a different owner. ${ }^{260}$

Some of these difficulties might be addressed if the bargaining occurred ex post, after the follow-on improver had already developed the improvement. In that case, both the initial inventor and the follow-on

256 See Heller \& Eisenberg, supra note 1, at 701 (arguing that scientists in general may be biased due to commitments to research hypotheses and that scientists trained in deterministic rather than probabilistic disciplines may have a particularly difficult time gauging probabilities of success). See also Christine Jolls et al., A Behavioral Approach to Law and Economics, 50 STAN. L. REV. 1471, 1501-04 (1998) (discussing the general phenomenon of self-serving biases).

257 See Arrow, supra note 215, at 615. The bargaining difficulties caused by Arow's information paradox have been discussed extensively. See, eg., Lemley, supra note 255, at 1050-51; Robert Merges, Intellectual Property Rights and Bargaining Breakdown: The Case of Blocking Patents, 62 TENN. L. REV. 75, 81-82 (1994).

258 See Lemley, supra note 255, at 1053-54 (making this point about transaction costs generally). Moreover, even without the costs created by problems of valuation and by Arrow's information paradox, the mere drafting and monitoring of a complex license that sets up an ongoing relationship may be costly. See id. at 1053.

259 See Heller \& Eisenberg, supra note 1, at 699. Professors Heller and Eisenberg characterize this carving up of property rights into small pieces that are then difficult to aggregate in socially useful ways as a problem of the "anticommons." See id. Just as "commons" property can lead to overuse, Heller and Eisenberg argue that there may be a corresponding underuse of "anticommons" resources in which a large number of private parties can assert property rights. See also Michael A. Heller, The Tragedy of the Anticommons: Property in the Transition from Marx to Markets, 111 HARV. L. REV. 621, 677 (1998) (arguing that a tragedy of the anticommons can occur when too many individuals have rights of exclusion in a scarce resource).

${ }^{260}$ See Heller \& Eisenberg, supra note 1, at 699. 
improver would have greater knowledge of the value of the improvement relative to that of the original invention. Moreover, in the ex post situation, the possibility of "blocking patents" might provide a way around Arrow's information paradox. Blocking patents arise when a follow-on improver takes a patented product and improves it in a nonobvious way. ${ }^{261}$ Although the follow-on improver can then secure a patent on that improvement, the improvement may nonetheless infringe the original patent. ${ }^{262}$ In the blocking patent situation, neither the initial patent holder nor the follow-on improver can sell the improvement without cross-licensing. But, if the improvement is truly significant, such that the initial inventor would want to sell the improvement itself, it would presumably have a financial incentive to cross-license the improver.

In the context of biotechnology, blocking patents might arise in the following manner. A researcher has independently characterized and patented a full-length gene. There is, however, already a prior patent on an EST that forms part of the gene. ${ }^{263}$ Because the prior patent holder and the researcher must cross-license one another in order for either to continue work in the area, they should both have incentives to conclude a crosslicensing arrangement.

This argument does not take into account, however, at least two difficulties. First, if the follow-on improver has to wait until after it has a patent in order to conduct the bargaining, its incentive to invest in the improvement in the first instance will be tempered by uncertainty regarding whether an improvement patent will eventually issue as well as uncertainty regard-

261 See supra note 129 (discussing patentability requirement of nonobviousness).

262 For example, if the improver "adds on" to the original invention, that improvement will necessarily use the original invention. In the case of Marconi Wireless Telegraph Co. of Am. v. De Forest Radio Telephone \& Telegraph Co., 236 F. 942 (S.D.N.Y. 1916), aff'd 243 F. 560 (2d Cir. 1917), the court held that the De Forest company's patented triode (a three-electrode container) infringed Marconi's patented diode (a two-electrode container) because the triode necessarily contained two electrodes. For a discussion of this and other situations in which blocking patents may arise, see Lemley, supra note 255 , at 1009.

263 The PTO has indicated that precisely this type of blocking patent situation might arise with respect to full gene sequences and ESTs. See John J. Doll, The Patenting of DNA, 280 SCIENCE 689, 690 (1998) (statement by PTO's Biotechnology Examination director that PTO might grant patent application for full gene sequence even if sequence included an EST on which there was a patent). Blocking patents could not arise if the EST patent application had broadly claimed not only the EST but also the full gene and such a claim were upheld. In that case, the full gene would be obvious in light of the prior art and the bargaining situation for the researcher with the full-length gene would be very difficult indeed. However, given the CAFC's strict interpretation of the written description requirement, it is unlikely that broad claims on ESTs would be upheld. Moreover, the PTO has recently indicated some reluctance to grant broad claims on ESTs. See id. (noting that, in the context of EST patent applications, "[t]he granting of comprehensive claims to downstream DNA products such as full-length genes or to ultimate proteins is unlikely in the absence of a significant amount of information about the gene and protein being disclosed in the patent application."). Thus, for example, the scope of Incyte's EST patent is not entirely clear, see supra note 150 , even though Incyte's patent application did reveal quite a bit of information regarding the gene with which the ESTs were associated. See supra note 166. 
ing whether a cross-licensing arrangement with the prior patent holder will be concluded. ${ }^{264}$ In addition, in the context of cross-licensing, there is the significant possibility of strategic behavior. ${ }^{265}$ The original patentee might want to use its patent as a "holdup" right, so as to appropriate as much of the value of the improvement as possible. Holdup rights are a particular problem if the original patent contributes very little value relative to the improvement-as is likely to be the case with respect to the EST in question, particularly if the holder of the EST patent had claimed an EST of unknown function. In that case, the holder of the original EST patent may be able to extract value significantly greater than its actual contribution to the followon improver's characterization of the entire gene. Consider a situation where the original EST patent has a value of $\$ 100,000$ (an arbitrary figure). The full gene, which is also patented, is worth $\$ 900,000$ (also an arbitrary figure). Even if the EST patent holder demands "only" an equal allocation of the improvement's value, ${ }^{266}$ the improver is limited to $\$ 450,000$ of the total value of the improvement. ${ }^{267}$ To the extent that the improver is shortchanged, incentives to improve in the first place diminish dramatically. At a minimum, holdup strategies produce delay and increase transaction costs. In addition, there is of course the worst case scenario of deadlock in which the parties cannot agree and the significant improvement is not used at all. As Robert Cooter has pointed out, deadlocks are predictable where the bargaining parties are acting rationally. ${ }^{268}$ All of these transaction cost problems would, of course, only be exacerbated if not one but several parties held EST patents that could block development of the gene in question.

Finally, there may be cases where the improver's product competes with an alternative product developed by the patent owner. In those cases, although the licensing might produce a large social benefit in terms of competition, the improver will not be able sufficiently to capture the value of this competition so as to be able to pay the original inventor the full value of the license. Because of this "positive externality" problem, an otherwise efficient licensing agreement may not be concluded. ${ }^{26}$

Significant obstacles to efficient bargaining are likely to be created not only by the patenting of upstream discoveries but also by the restrictive materials transfer agreements (MTAs) used by many corporate owners of research tools. Because these MTAs typically give the entity that is licens-

\footnotetext{
264 See John H. Barton, Patent Breadth and Antitrust: A Rethinking (Nov. 27, 1995) <http//wwww.ftc.gov/ opp/global/barton.htm> (statement before the Federal Trade Commission).

${ }^{265}$ Strategic behavior (along with the problem of positive externalities, see infra text accompanying note 269) may also create obstacles to bargaining in the context of an ex ante bargain.

266 Notably, there is nothing to prevent the original inventor from extracting even more of the value.

267 Robert Merges has offered this example of strategic bargaining. See Merges, supra note 267, at 79 (1994); Merges \& Nelson, supra note 240, at 866 n.117.

268 See Robert Cooter et al., Bargaining in the Shadow of the Law: A Testable Model of Strategic Behavior, 11 J. LEGAL STUD. 225, 226 (1982).

269 Lemley, supra note 255 , at 1057-58.
} 
ing the research tool the right to control its future use, those who are attempting to develop a product that relies on many different research tools may be confronted with inconsistent and overlapping obligations. ${ }^{270}$

2. Collective Exchange Norms as a Mechanism for Addressing Transaction Costs. It might be argued that many of the transaction cost difficulties associated with a proliferation of property rights represent only a temporary problem. On this view, owners of intellectual property rights who are repeat players in a given market can address these problems with different norm-like mechanisms of either a formal or informal nature. ${ }^{271}$ Formal mechanisms might include patent pools, ${ }^{272}$ while more informal mechanisms might include systems in which patents are not fully enforced but are used as "bargaining chips."273 If the likelihood that these norms of collective exchange will emerge is high, then the transaction cost difficulties associated with granting extensive property rights are mitigated. ${ }^{274}$ In any discussion of the applicability of law-and-norms theory to scientific research, the issue of collective exchange norms with respect to patents therefore merits attention. What this attention reveals, however, is that myriad factors tend to inhibit the emergence of collective exchange norms in the context of a patent regime, and thus the beneficial effects that such norms could have on transaction costs are not achieved.

The formal mechanism of patent pools aggregates patent rights for the purpose of reducing the transaction costs associated with licensing. Patent pools typically function by extending membership to those firms in a given industry that agree to assign or license their individual patent rights to the pool. In simple pools, membership gives each party the right to royalty-free licensing of all patents in the pool. In more sophisticated pools, members who use a particular patent pay the pool a set fee that reflects the economic significance of the patent; similarly, royalties accumulated by the pool are divided according to the perceived significance of the technology put in by the parties. ${ }^{275}$ As for those who cannot contribute patented technology and

\footnotetext{
270 See Heller \& Eisenberg, supra note 1, at 699. Professors Heller and Eisenberg also note that the use of restrictive MTAs "gives each upstream patent owner a continuing right to be present at the bargaining table as a research project moves downstream toward product development." II.

271 See generally Merges, supra note 3. Merges himself discusses norms as a means of addressing the transaction cost problems associated with proliferating copyrights in digital media. He offers normbased institutions as an alternative to legislative approaches such as compulsory licensing.

272 See id. at $1340-52$.

273 See id. at $1352-54$.

274 It is important to note, however, that the operation of patent pools and norms against full patent enforcement is significantly at odds with part of Kitch's rationale for the patent grant. As discussed further below, see infra Part III.B.2, patent owners that join pools or do not fully enforce their patents generally lose the ability to orchestrate the development of their technological prospects. This is because they lose discretion to determine precisely how, and to whom, their patents should be licensed.

275 See generally id. at 1340-42.
} 
thus remain outside the pool, they may be able to secure a license to the patents in the pool by paying a licensing fee. ${ }^{276} \mathrm{~A}$ possible informal norm-like mechanism of collective exchange would be an understanding among industry participants mutually to refrain from full enforcement of their various patents. Rather than enforcing patents legally, firms would primarily keep tabs on whether there was a rough balance in the extent to which firms were infringing one another's patents.

There are, however, reasons to doubt that norms of collective exchange will emerge in biotechnology. First, the historical record regarding patent pools and informal licensing norms is not promising; to the contrary, the record bears out the institutional economists' thesis that the formation of institutions with collective exchange norms can be quite difficult. ${ }^{277}$ In addition, even when patent pools do form, they can restrain competition by withholding access to the pool from entities that do not have an important technology to contribute to the pool or that will not pay a large sum to purchase a license. Finally, as unpromising as the general historical record is, particular features of the biotechnology industry make it even less likely that cooperative norms with respect to patent rights will emerge there. $\mathrm{Be}$ low, I discuss each of these arguments in turn.

a. The History of Collective Exchange Norms.-The two most historically prominent pools arose in the automobile and aircraft industries. In both of these industries, patent pools formed only after significant litigation and refusal to license. In the automobile industry, George Selden received a broad patent claiming a gasoline-powered internal combustion engine in $1895 .^{278}$ Although Selden (or more specifically, the Electric Vehicle Company (EVC), which was Selden's exclusive licensee) was willing to license those who acknowledged the validity of the patent and were

\footnotetext{
276 For example, a patent pool recently approved as pro-competitive by the U.S. Department of Justice (DOJ) includes all patents deemed technically "essential" to the operation of the video and/or systems parts of the MPEG-2 compression technology standard. The companies that control licensing of the patent pool (each of whom has contributed at least one patent to the pool) have agreed to license the patent portfolio on a nondiscriminatory basis to all licensees who request a portfolio license. See Business Review Letter from Joel I. Klein, Assistant Attomey General, DOJ, to Garrard R. Beeney, Esq., Sullivan \& Cromwell (June 26, 1997), reprinted in Technology Licensing and Litigation 1998: Protecting Your Clients' Rights, 514 PLI/Pat 729 (1998). Another DOJ-approved patent pool, which encompasses all patents essential to manufacturing Digital Versatile Discs (DVDs) and players in compliance with certain technical formats, will also be licensed on a nondiscriminatory basis to all interested parties. See Phillips, Sony, and Pioneer Business Review Letter, from Joel I. Klein, Assistant Attomey General, DOJ, to Garrard R. Beeney, Esq., Sullivan \& Cromwell (Dec. 16, 1998), reprinted in Handling Intellectual Property Issues in Business Transactions, 55 PLI/Pat 201 (1999). Few lessons can, however, be gleaned from the fact that these particular pro-competitive pools were able to form. These pools address the unusual situation where the use of the pool inventions is entirely clear and where the inventions are useful only in conjunction with each other.

277 See supra note 50 and accompanying text.

278 See WILLAM GREENLEAF, MONOPOLY ON WHEELS: HENRY FORD AND THE SELDEN AUTOMOBILE PATENT 38, 40 (1961).
} 
willing to pay royalties, ${ }^{279}$ many questioned its validity. ${ }^{280}$ In 1903, after years of litigation, a group of auto manufacturers (who came to be known as the Association of Licensed Automobile Manufacturers (ALAM)) signed an agreement with EVC. Under the agreement, ALAM members would license the patent from EVC and would also have control over who would be granted a license. ${ }^{281}$ Ultimately, ALAM authorized its members to use not only the Selden patent but also the other patents held by its members. ${ }^{282}$

ALAM was, however, far from an idealized, pro-competitive patent pool arrangement. To the contrary, in order to restrain competition, ALAM severely restricted the group of auto manufacturers to whom the benefits of pool membership would be extended. Most manufacturers who applied, including Henry Ford, were denied licenses. ${ }^{283}$ When Ford decided to proceed into auto manufacture despite his inability to secure a license, litigation ensued. The ALAM/Ford dispute (in which Ford was eventually vindicated ${ }^{284}$ ) developed into litigation that lasted virtually until the time the Selden patent was due to expire. Only after this long-running and contentious dispute concluded did auto manufacturers determine that there was much to be gained from a comprehensive, pro-competitive patent pool: under a patent pool agreement signed in 1915, seventy-nine companies agreed to royalty-free reciprocal licensing. ${ }^{285}$

A similar story of restrictive licensing and heated litigation attended the eventual emergence of a patent pool in the aircraft industry. Indeed, in the aircraft industry, government intervention was ultimately necessary. The patent struggles in the aircraft industry began in 1906 with the grant to Wilbur and Orville Wright of a broad patent on an aircraft stabilization system. Because the Wright brothers were unable to work out licensing agreements with potential competitors, they engaged in repeated litigation over the next ten years. ${ }^{286}$ Moreover, despite the efforts of industry leaders and the government's National Advisory Committee for Aeronautics (NACA), licensing agreements could not be worked out. The deadlock persisted even after the United States' entry into World War I. ${ }^{287}$ A cross-

279 See id. at 67-68.

280 See id. at 74-82. In a variety of lawsuits, these manufacturers offered extensive evidence to support their argument that the patent was not novel. See id.

281 See id. at 96-98.

282 See id. at 243.

283 See id. at 101-102, 106-108, 173-75.

284 The Second Circuit determined that if the Selden patent was to be construed broadly, it was invalid; if it was construed less broadly, Ford did not infringe. See Columbia Motor Car Co. v. C.A. Duerr \& Co., 184 F. 893 (2d Cir. 1911).

285 See GREENLEAF, supra note 278, at 244-46. It bears noting that in later years, after objections were raised that many small firms that contributed no patents to the pool also enjoyed the benefits of royalty-free licensing, this arrangement was altered. See id. at 246.

286 See JACOB A. VANDER MEULEN, THE POLITICS OF AIRCRAFT 19 (1991).

287 See id. at 21-22. 
licensing scheme was achieved only after the United States had been at war for several months, and only then because of direct pressure from the Army and Navy, who were the prime buyers of aircraft. ${ }^{288}$

Another norm-like mechanism through which the transaction costs associated with extensive patenting could be addressed is an informal understanding among patent holders mutually to refrain from patent enforcement. Arguably, this norm has existed at certain points in particular fastdeveloping industries. One prominent example is the semiconductor industry. ${ }^{289}$ In the semiconductor industry, however, government involvement played a role in the development of cooperative norms. Government action was important at two distinct stages in the evolution of the industry. At the first stage, AT\&T, which had a broad transistor patent, was kept out of the commercial transistor market by an antitrust consent decree. Because AT\&T needed sophisticated transistor technology for its phone system, it licensed its patent widely so that improvements could be made on it. ${ }^{290}$ At the second stage, two companies-Texas Instruments and Fairchild Instruments-respectively obtained patents on the integrated circuit and the Planar process for producing such circuits. In order for either to produce integrated circuits, each company had to license the other. The Department of Defense, which provided a large share of the market for semiconductors, pressured the companies to cross-license. ${ }^{291}$

Thus, the historical record makes it clear that collective exchange norms with respect to patents emerge only with difficulty. Moreover, even

288 See id. at 26. In the copyright context, the emergence of collective rights organizations has similarly been shaped through intervention by the public sector. Both ASCAP and BMI-copyright collectives that license performance rights in music-operate under antitrust consent decrees that govern their membership, governance, and licensing practices. As Julie Cohen has pointed out, "[t]he decrees require ASCAP and BMI to make membership available on a nondiscriminatory basis, to issue licenses to all who request them, and to accept a judically determined 'reasonable fee' (ASCAP) or a fee determined by an arbitrator (BMD) in the event of a dispute... [T] he decrees prohibit ASCAP and BMI from holding or licensing any rights in copyrighted musical compositions other than the public performance rights." See Cohen, supra note 15, at 501. See also Stanley M. Besen et al., An Economic Analysis of Copyright Collectives, 78 VA. L. REv. 383, 387-88 (1992) (noting that collectives are subject to regulation regarding types of licenses offered, license fees, and membership restrictions).

${ }^{289}$ See Merges, supra note 3, at 1353-54. The following description of the norm is taken from interviews with corporate patent attomeys in the semiconductor field:

Firm A's corporate patent department will wait to be notified by attorneys from firm $B$ that it is suspected that A's activities are infringing B's patents. Since possibly germane patents and their associated claims are so numerous, it is in practice usually impossible for firm A-or firm $B$ - to evaluate firm B's claims on their merits. Firm A therefore responds-and this is the true defensive value of patents in the industry - by sending firm B copies of "a pound or two" of its possible germane patents with the suggestion that, while it is quite sure it is not infringing $B$, its examination shows that $B$ is in fact probably infringing $A$. The usual result is cross-licensing with a modest fee possibly being paid by one side or the other.

Eric Von Hippel, Appropriability of Innovation Benefit as a Predictor of the Source of Innovation, 11 RESEARCH POL'Y 95, 102 (1982).

290 See Merges \& Nelson, supra note 240 , at 894.

291 See id. 
when patent exchange norms do emerge, they can be anti-competitive, as when the ALAM group denied membership to Henry Ford and others for anti-competitive reasons. More generally, entities may be denied access to the patents held by a pool if they do not have a new technology to contribute to the pool or are unable to pay large amounts of money to purchase a license: for these entities, the existence of institutions with licensing norms raises rather than lowers barriers to entry. ${ }^{292}$

b. Special Issues in the Biotechnology Industry.-Patent exchange norms that promote competition are even less likely to emerge in the biotechnology industry than in the historical examples analyzed above. As proponents of such norms acknowledge, the strength of the norms depends on how much agreement there is on the value of individual patents. ${ }^{293}$ In the biotechnology industry, the likelihood of such agreement is very low. This is because many of the inventions that would have to be included in the patent pool-SNPs, ESTs, receptors, and the like-represent very preliminary, difficult-to-value steps in the research and development process. Moreover, difficulty in valuation may allow more room for the various cognitive biases discussed earlier ${ }^{294}$ to play a role.

In addition, as discussed in Part $I$, research on cooperative norms demonstrates that these norms typically emerge where the parties involved have long-term, enduring relationships and are relatively homogeneous. ${ }^{295} \mathrm{By}$ contrast, the relevant players in the biotechnology industry include institutions with very different agendas-everything from federal agencies to academic institutions and various different types of private companies. ${ }^{296}$ In the context of a patent pool, the heterogeneous parties involved in a patent pool would have difficulty reaching agreement on the licensing policy the pool should adopt. For example, even if academic institutions, federal agencies, and private entities focused on developing marketable end products were able to reach agreement on making certain basic inventions widely available nonexclusively on a low or no-royalty basis, private companies focused exclusively on upstream research might believe in more selective licensing at a higher royalty. ${ }^{297}$ Indeed, many private companies with large numbers of patents on upstream information might not be interested in entering the pool at all; their comparative advantage might lie not in using any of the upstream information generated by other companies, but

\footnotetext{
292 For further discussion of the problem of anticompetitive behavior by patent pools, see Barton, supra note 155 , at $463-64$.

293 See Merges, supra note 3, at 1353 (making this point in the context of norms that counsel against full enforcement of patent rights). See also id. at 1345 (noting that voting in aircraft patent pool was weighted according to the economic value of the patents contributed).

${ }^{294}$ See supra note 256 and accompanying text.

295 See supra 40-45 and accompanying text.

296 See Heller \& Eisenberg, supra note 1, at 700.

297 See id.
} 
in securing lucrative, exclusive licensing contracts on their own upstream information. Moreover, even if these lucrative licensing contracts were not concluded because of high transaction costs, ${ }^{298}$ companies with patents on upstream research could profit by suing developers who deliberately or inadvertently used patented information.

For example, in the case of ESTs, companies focused on the development of end products have taken an attitude towards patentability very different from that of companies focused on upstream research. While HGS and Incyte have filed patent applications on ESTs (and have also maintained post-filing secrecy), ${ }^{299}$ the pharmaceutical firm Merck \& Co. has put into the public domain the results of an EST identification project it sponsored at Washington University. ${ }^{300}$ In making these results widely available, Merck hopes to take advantage of the efforts of those who will use the results to do fundamental research. In other words, Merck believes that its own comparative advantage lies in using the fundamental research of others to do downstream work directed towards the formulation of particular drugs. $^{301}$ Similarly, in the context of SNPs, a number of pharmaceutical companies have formed a non-profit collaboration, known as the SNP Consortium, that aims to identify and place in the public domain information about the approximately 300,000 SNPs in the human genome. ${ }^{302}$ The pharmaceutical companies, whose comparative advantage lies in developing basic research about SNPs, are racing to catch up with various biotechnology companies, such as Incyte, Millenium Pharmaceuticals Inc., and Genset, that have already filed patent applications on this upstream research. ${ }^{303}$ Notably, even this limited collaboration among pharmaceutical companies only came to pass after the Wellcome Trust, a London charity that works closely with the NIH (and is a co-sponsor, along with the NIH, of the public effort to sequence the genome) promised to provide approximately half the funding for the consortium. ${ }^{304}$

Similar difficulties would be likely to emerge in the context of informal licensing norms. While academic institutions and pharmaceutical firms that were interested in the development of end products might be willing to forgo patents (or at least full patent enforcement), it is unlikely that firms

298 See supra notes 254-69 and accompanying text.

299 See supra note 149 and accompanying text.

300 See Eisenberg, supra note 1, at 559.

301 See id. at 570.

302 See Nicholas Wade, 10 Drug Makers Join to Find Genetic Roots of Diseases, N.Y. Times, Apr. 15,1999 , at A19.

303 See Robert Langreth et al., DNA Dreams: Big Drug Firms Discuss Linking Up to Pursue Disease-Causing Genes, WALL ST. J., Mar. 4, 1999, at A1, A8.

304 See Wade, supra 302 (noting that the Wellcome Trust is putting in $\$ 20$ million out of a total budget of \$45 million). See also Matthew Lynn, Wellcome Seeks Alliance to Keep Genes Data Public, LONDON SUNDAY TIMES, Aug. 30, 1998, at 1 (noting efforts by Wellcome Trust and the NIH to set up what was to become the SNP Consortium). 
engaged in upstream research would be willing to do so. Indeed, we already have some empirical evidence of the difficulty involved in developing collective exchange norms to govern all of the diverse actors in the biotechnology industry. While various academic institutions managed to develop an agreement, the UMBTA, ${ }^{305}$ to facilitate the transfer of research materials among academic researchers, efforts to develop a broader agreement that included industry actors met with little success. ${ }^{306}$

It could be argued that while it is unlikely that collective exchange norms will emerge spontaneously in the biotechnology industry, government involvement can encourage the development of these norms (as it did, for example, in the aircraft and semiconductor industries). Whether government policy can do much to foster a broad industry consensus in favor of crosslicensing (formal or informal) is, however, unclear. For example, while the government exerted market power in the aircraft industry and in the early days of the semiconductor industry, it does not do so in biotechnology today. ${ }^{307}$ In the context of biotechnology, the best government may be able to do is encourage public domain-oriented ventures by particular segments of the industry (as it appears to have done in the case of the SNP Consortium).

In sum, an aggressive patenting policy of the sort advocated by the development-oriented theorists (and embodied, to a significant extent, in post1980 law) has several drawbacks. First, in the context of both basic and applied research, coordination by a single rightsholder is likely to hinder creativity. In addition, extensive property rights in basic research are not likely to promote development. Although property rights in basic inventions may provide some hedge against the labor and capital expenditures involved in developing these inventions, they can dramatically increase the transaction costs associated with development. With respect to any given basic invention, patent policy should pay attention not only to the labor and capital costs of development but also to the costs of granting a patent-both the transaction costs of licensing and costs in terms of reduced creativity. More specifically, patent policy should aim towards privatizing only that range of invention that would be used most effectively through allocation to a single rightsholder; invention that would be used most effectively through open access should be left in the public domain. In the next Part, I address the challenge of constructing this "efficient" public domain. After discussing the costs that have to be balanced in constructing this public domain, I focus on the relative efficacy of two institutions-first, law alone, and second, the combination of law and norms-in balancing these costs.

\footnotetext{
${ }^{305}$ For discussion of the UMBTA, see supra text accompanying notes 201-04.

306 See supra text accompanying note 202.

307 However, it should be emphasized that there is a substantial amount that government policy can, and should, do to reinforce academic research norms against expansive patenting. See infra Part IV.C.
} 


\section{TOWARDS AN EFFICIENT PUBLIC DOMAIN: THE ROLE OF LAW AND NORMS}

In the context of basic research, ${ }^{308}$ patent policy should consider, and balance appropriately, all costs relevant to the creation and development process. The two most prominent costs will generally be the transaction costs of licensing if a patent were to be granted ("transaction costs") and the labor and capital costs of development exclusive of any transaction costs ("pure development costs"). A third cost that should be addressed is the reduced creativity that is likely to result if basic research is coordinated by a single rightsholder ("creativity costs"). Finally, a fourth cost that may be high enough in certain circumstances to merit consideration is the cost of inventing the research on which a patent application is sought ("invention costs"). The ultimate goal of balancing these four costs is to construct a public domain that includes all of the inventions that are best used through open access. In this Part, I argue that this goal can and should be achieved, at least in part, by using the law to reinforce residual academic norms that continue to militate against expansive patenting. The argument proceeds in three parts. First, I summarize how transaction costs, pure development costs, creativity costs, and invention costs should be balanced. Second, I discuss the difficulties associated with attempting to implement this balance strictly through changes in the patent law. Finally, I argue that a synergistic combination of norms and law would represent a valuable, and heretofore underutilized, mechanism for implementing this balance.

\section{A. Constructing the Public Domain: A Balance of Costs}

In theory, the challenge of balancing four different cost variableseach of which might be either low or high-could involve a variety of permutations. In practice, however, the variable of pure development costs in biotechnology is relatively stable because these costs are usually high-it generally takes a significant investment to go from basic research to a product that is ready for clinical testing. ${ }^{309}$ As suggested by the discussion in Part III, one scenario that is likely to arise (and, indeed, has already arisen with respect to EST and SNP patent applications) is the situation where pure development costs are high, transaction costs are high (because licensing agreements will be difficult to conclude, and multiple licensing agreements will be necessary to use the research effectively), creativity costs are high (because the research on which a patent is sought suggests multiple possible research avenues and improvements), and invention costs

\footnotetext{
308 I illustrate the economic analysis outlined in this part by focusing on basic research. This is because basic research is most likely to raise difficult questions about balancing the various costs relevant to the creation and development process. (By contrast, the cost balancing with respect to applied research is likely to point rather straightforwardly towards patenting.) Nonetheless, the economic analysis applies equally to all research, basic and applied.

309 See supra note 237 and accompanying text.
} 
are low (because the basic research is relatively easy to generate, particularly given the labor subsidy provided by the invention norm). In this situation, the only advantage of granting a patent-namely, encouraging the investment of labor and capital in development-is likely to be outweighed by the disadvantages of high transaction and creativity costs. By contrast, in a situation where pure development costs are high and transaction costs relatively low (because the uses of the invention in question are clear and can be exploited through a single contract between inventor and developer), creativity costs are also likely to be low. In this latter scenario, the development-related advantages of granting a patent probably outweigh the transaction and creativity cost disadvantages. If, in this latter scenario, invention costs are also high, a patent may be necessary to encourage investment in invention itself, and thus the balance may tilt further in favor of granting a patent.

Of course, the decision regarding whether or not to grant a patent does not represent the only occasion when transaction, pure development, creativity, and invention costs have to be balanced. Such balancing decisions are also necessary when deciding the proper scope of a patent, the terms under which the patent should be licensed, and the availability of defenses to possible future assertions of patent infringement. As to this latter point, even after a patent is granted, patent policy might strive to reduce transaction and creativity costs by interpreting the patent narrowly (particularly if invention and/or pure development costs are low and hence strong patent rights are not necessary to provide an incentive to invent and/or develop the patented item). As a consequence of this balancing, the public domain will, in all likelihood, be sufficiently enriched so as to ensure adequate development of invention best developed through open access.

As an institutional matter, how might the appropriate balance between transaction costs, pure development costs, creativity costs, and invention costs be struck? In Parts IV.B and IV.C, I address two possible alternatives: the more obvious alternative of strictly legal change and the less obvious alternative of legal change that reflects and reinforces efficient norms. I argue that the significant problems associated with the strictly legal approach commend attention to the alternative of preserving a public domain through the combination of law and norms. ${ }^{310}$

\section{B. Strictly Legal Change}

Strictly legal change could achieve the appropriate balance between the various costs at issue in several different ways. In situations where transaction and creativity costs were high and invention costs low, legal changes

310 My comparison of law with norms represents a comparative institutional analysis of sorts. Comparative institutional theorists focus on the relative capacity of different institutions such as the legislature, the market, and the courts to address social policy problems. See, e.g., NEIL KOMESAR, IMPERFECT CHOICES: CHOOSING INSTITUTIONS IN LAW, ECONOMICS, AND PUBLIC POLICY (1994). 
could discourage patenting. Alternatively, legal changes could allow patenting but reduce transaction and creativity costs by curtailing the strength of the patent. Given the difficulty of determining the mix of cost variables in each case and the administrative costs of making these determinations, however, it is unlikely that strictly legal changes could be made sufficiently precise to avoid the problems that motivated the changes in the first place.

Changes that focused on discouraging the patenting of basic research might urge stricter interpretation of the "utility" requirement for patenting. For example, if the utility requirement were interpreted as strictly as in the days of Brenner v. Manson, inventions that were primarily useful as tools for future researchers might not be patentable: they would not offer the specific commercial utility required by the Supreme Court in that case. ${ }^{312} \mathrm{~A}$ more complex approach to strengthening the utility requirement might use the requirement as a proxy for doing an economic analysis of the optimal invention and development arc for any given invention. Thus, if the sum of transaction and creativity costs was high relative to the sum of invention and pure development costs, there would be a presumption against patenting. ${ }^{313}$

Another legal change that would discourage the patenting of basic research (as well as other research) might involve a clarification of the nonobviousness standard in the context of DNA. As matters currently stand, because the CAFC views DNA as an ordinary chemical, it refuses to characterize methods of isolating DNA as relevant prior art. Thus, DNA sequences can be nonobvious irrespective of how simple it is to isolate the sequence..$^{314}$ The patent statute could be altered in order to make it clear that DNA sequences should be treated not simply as chemicals, but also as biochemical information that can be derived (via the combination of common biotechnological techniques and the genetic code) from other biochemical information.

Alternatively, legal change might focus not on whether the initial patent should have been granted, but rather on ways in which the patent law could reduce the transaction and creativity costs associated with development/improvement. These costs might be reduced, for example, if the initial patent were interpreted in a narrow fashion rather than in the broad fashion advocated by the development-oriented theorists. ${ }^{315}$

\footnotetext{
311 See supra text accompanying notes 130-34.

312 See Eisenberg \& Merges, supra note 1, at 19 (outlining arguments against the patentability of research tools).

313 Such an explicitly economic approach would, of course, represent a significant departure from conventional interpretations of the utility requirement. However, the current statutory language regarding usefulness, see 35 U.S.C. $\$ \S 101,112$ (1994), may well be general enough to encompass an economic approach. Moreover, Congress could always amend the statute to allow for an explicitly economic approach to utility.

314 See supra notes 171-76 and accompanying text. See also Eisenberg \& Merges, supra note 1, at 32 (noting that the CAFC's position collapses the novelty and nonobviousness requirements for DNA sequences).

315 See generally Merges \& Nelson, supra note 240 (arguing in favor of giving a relatively narrow scope to patent claims). Cf. Barton, supra 155 (arguing that when a patent claims a broad scope, a retro-
} 
Another mechanism for reducing transaction and creativity costs might involve a broader interpretation of the so-called "experimental use" exemption to infringement liability. As currently structured, this exemption is extremely narrow. It applies only when the patented invention is being used for strictly "philosophical" purposes that have absolutely no commercial implications. ${ }^{36}$ The prototypical example of such a use would be checking the patented invention against the claims made in the patent. As Rebecca Eisenberg has argued, a broader interpretation of the exemption might encompass the research use of inventions in developing improvements, including commercially valuable improvements. ${ }^{317}$ In the context of a commercially valuable improvement (which might or might not infringe the claims of the original patent), the improver would simply have to pay a reasonable royalty to the patent holder after the fact. ${ }^{318}$ Notably, such use of the experimental use exemption would not be very different from a compulsory license scheme or a scheme in which intellectual property rights were enforced by liability rules (i.e., rules that address infringement by requiring the payment of damages) rather than property rules (i.e., rules that simply enjoin infringement). ${ }^{319}$

active administrative mechanism to review the scope of the claims could be set up so that "when evidence evolves that these claims have not really been enabled, they can be narrowed"). Arguably, in the context of biotechnology, the Federal Circuit is in fact giving patent claims a narrow scope. See supra note 176 (discussing strict Federal Circuit interpretation of written description requirement). The strictness with which the Federal Circuit has interpreted the requirement is, however, more than counterbalanced by its liberal interpretation of the nonobviousness requirement. See supra notes 171-76 and accompanying text.

316 See, e.g., Roche Products, Inc. v. Bolar Pharm. Co., 733 F.2d 858, 863 (Fed. Cir. 1984) (suggesting that exemption could be invoked when the use of the patented invention was "for amusement, to satisfy idle curiosity, or for strictly philosophical inquiry"); Jordan P. Karp, Note, Experimental Use as Patent Infringement: The Impropriety of a Broad Exemption, 100 YALE L.J. 2169 (1991) (emphasizing narrow scope of exemption). As was noted in the text, the experimental use exemption is a judicial creation; it has no statutory foundation. There is, however, a narrow statutory exemption from infringement if one is using a patented drug in testing for the purposes of gathering information for the regulatory approval process. 35 U.S.C. § 271(e)(1) (1994).

317 See Eisenberg, supra note 75, at 1078. Eisenberg's argument focuses on the multiple difficulties peculiar to negotiating improvement licenses. Therefore, she would not expand the experimental use exemption to include situations in which the researcher was not an improver but, rather, merely an ordinary user. Id. Thus, for example, the researcher who was using a patented electron microscope to do research in molecular biology could not invoke Eisenberg's expanded version of the experimental use exemption.

${ }^{318}$ See id. The difficulties that might be involved in determining a reasonable royalty are discussed infra notes 325-26 and accompanying text.

319 See, e.g., Barton, supra note 155 (arguing for compulsory licensing where the patented invention must be used to make improvements, particularly significant improvements); Irving N. Feit, Biotechnology Research and the Experimental Use Exception to Patent Infringement, 71 J. PAT. \& TRADEMARK OFF. SOC'Y 819,840 (1989). That commentators have advocated liability rules as a way of overcoming transaction costs in the intellectual property context is not surprising: the traditional literature on legal entitlements also regards liability rules as the preferred entitlement when certain types of high transaction costs, such as those associated with multiple parties and the likelihood of strategic bargaining, are 
Finally, as Robert Merges has suggested, the relatively obscure patent law doctrine of the "reverse doctrine of equivalents" might be used to reduce bargaining breakdown between inventors and follow-on improvers who had blocking patents. ${ }^{320}$ The straightforward doctrine of equivalents expands the scope of patent claims by bringing within their scope inventions that do not infringe the claims literally but, rather, accomplish substantially the same result in substantially the same way. By contrast, the reverse doctrine of equivalents can defeat liability even when improvements literally infringe the claims of the original patent. More specifically, the reverse doctrine of equivalents may be invoked when "a product precisely described in a patent claim is in fact 'so far changed in principle' that it performs in a 'substantially different way' and is not therefore an appropriation." equivalents could be applied expansively, to all situations where courts found that the improver had done "very substantial additional research" such that the "value-added" of the improvement was large. 322

Each of these proposed legal approaches has considerable problems, however. As an initial matter, some of the proposed changes may be insufficiently precise to address the problems posed by scientific research. Consider, for example, the idea that the utility requirement for patenting should be strengthened so as to exclude from patent protection inventions that do not have a specific practical function but, rather, are primarily useful as tools for future researchers. In the context of some molecular biology research, strengthening the utility requirement so as to exclude research tools is probably a good idea. For example, the incentive of a patent grant hardly seems necessary to generate relatively inexpensive research tools such as ESTs and SNPs. Moreover, if research tools such as ESTs and SNPs are held to be patentable, the associated transaction and creativity costs are likely to be high.

likely to arise. See Guido Calabresi \& A. Douglas Melamed, Property Rules, Liability Rules, and Inalienability: One View of the Cathedral, 85 HARV. L. REV. 1089, 1106-08 (1972).

320 See Merges, supra note 257; Robert P. Merges, A Brief Note on Blocking Patents and Reverse Equivalents: Biotechnology as an Example, 73 J. PAT. \& TRADEMARK OFF. SOC'Y 878 (1991). For a discussion of blocking patents, see supra notes 261-63 and accompanying text.

${ }^{321}$ SRI Int'l v. Matsushita Elec. Corp. of Am., 775 F.2d 1107, 1123 (Fed. Cir. 1985). The Supreme Court originally enunciated the reverse doctrine of equivalents in Graver Tank \& Mfg. Co. v. Linde Air Prod. Co., 339 U.S. 605 (1950). In the biotechnology area, the most prominent case to apply the reverse doctrine of equivalents was Scripps Clinic \& Research Found. v. Genentech, Inc., 927 F.2d 1565 (Fed. Cir. 1991). In that case, Genentech was accused of infringing the Scripps patent on a purified version of Factor VIII:C, a factor that is important in the blood clotting cascade. Genentech argued that even if its recombinant Factor VIII:C fell literally within the scope of Scripps' patent claims, Genentech should escape liability because its product was most equitably seen as changed "in principle." The Federal Circuit denied summary judgment on Scripps's infringement claim and remanded for trial on the reverse doctrine of equivalents issue. See id. at 1581.

322 Merges, supra note 320 , at 887-88. 
On the other hand, for some research tools-laboratory machines, analytical and purification methods, certain types of genetically engineered mice-the costs of invention may be fairly high. Equally important, because these research tools will, in many circumstances, be licensed not for further improvement but for the comparatively straightforward purpose of direct use, the transaction and creativity costs associated with licensing will be relatively low. ${ }^{323}$ Where transaction and creativity costs are low relative to invention costs, patent protection is probably desirable. Where the reverse is true, patent protection is probably undesirable. A blanket exclusion of research tools from patent protection on the grounds of failure to satisfy the utility requirement would not make these important distinctions. ${ }^{324}$ By contrast, using the utility requirement as a proxy for an economic analysis of the invention and development process could make such distinctions. This approach would allow patenting only if the sum of transaction and creativity costs of licensing was low relative to the sum of invention and pure development costs. However, requiring the PTO or the courts to do this type of complicated economic analysis would raise significant concerns regarding institutional competence and administrative costs. The task of predicting invention and development trajectories is difficult even for industry players.

Similar arguments can be raised against proposals that the PTO or the courts interpret initial or pioneer patents as having a narrow scope. While in some cases this narrow scope may be desirable, in other cases it may significantly undermine incentives to invent and/or develop. Requiring the PTO or the courts to do an economic analysis of the ratio of transaction and creativity costs to invention and development costs would strain their competence. Moreover, in the context of many basic molecular biology inventions-including ESTs, SNPs, and receptors-even patents with the narrowest possible scope are problematic. Even if a patent claimed only the EST, SNP, or receptor itself, anyone using the EST, SNP, or receptor for further research would be subject to infringement liability. In addition, with an EST or SNP patent, making or using any gene that contained the EST or SNP in question would infringe the patent.

Other proposals - such as expanding the "experimental use" exemption to allow for the equivalent of compulsory licensing in improvement contexts-rest on the assumption that courts will be able to come up with rea-

323 Of course, there may be problems of valuation, strategic behavior, and externalities associated even with direct use. But, because the patent holder and the licensee are not as likely to be competitors in the same field (for example, an equipment manufacturer is unlikely to be competing with a genome sequencing firm), these problems will not loom as large.

324 Indeed, in certain circumstances, it may be difficult even to discern whether a particular invention is a research tool or an end product. Certain gene sequences and receptors may be valuable not only as research tools but also as pharmaceuticals in and of themselves. See Nelsen, New Perspectives, supra note 181. See also NIH Working Group Report, supra note 190, at 4-5 (noting that some research tools may be useful as therapeutic or diagnostic products). 
sonable royalty figures in the context of intellectual property. But there is good reason to believe that courts are not well suited for such a task: the nature of the assets being traded is typically quite specialized. ${ }^{325}$ Moreover, for many upstream biotechnology inventions, valuation difficulties are likely to be unusually severe. Even private parties who are knowledgeable about the industry have a difficult time coming up with the appropriate valuations for these inventions. ${ }^{326}$

As for the reverse doctrine of equivalents, it is by no means clear that a relatively minor change in the patent doctrine that exempts from liability only those improvers who have made a "very substantial" change will be sufficient to address the transaction cost problems associated with extensive patenting. Indeed, because the reverse doctrine of equivalents requires that improvers actually invest in, and secure a patent on, the improvement before they can even assert the defense, risk-averse improvers are unlikely to take advantage of the doctrine.

In addition, as a general matter, modifying patent doctrine in order to address specific difficulties in basic biotechnology research is a very blunt approach. This modified doctrine would apply, after all, not only to biotechnology but also to other industries that clearly differ from biotechnology in terms of the nature and degree of intellectual property protection that is desirable. As one prominent economist has noted, achieving "economic efficiency would seem to call for great subtlety in the nature and degree of intellectual property protection provided, based on differences among industries in technological and market circumstances."327 Indeed, biotechnology and pharmaceutical firms are arguably unique in their heavy reliance on patents for commercial advantage; firms in other industries rely more heavily on such factors as lead time and secrecy.

325 See, e.g., Robert P. Merges, Of Property Rules, Coase, and Intellectual Property, 94 ColuM. L. REV. 2655, 2664-65 (1994) (discussing difficulties in valuation of intellectual property). Because of these difficulties in determining the value of the assets being traded, intellectual property is typically governed by property rules (rules that allow infringement only after ex ante bargaining with the entitlement holder) rather than liability rules (rules that allow infringement so long as appropriate compensation is paid ex post). See Calabresi \& Melamed, supra note 319, at 1106-08 (noting that one factor weighing in favor of property rules is difficulty in valuing the assets being exchanged). On this view, property rules are superior because they require private parties with knowledge superior to that of the court to negotiate ex ante. Some recent work has, however, questioned whether there is a sharp distinction between property rules and liability rules. Ian Ayres and Eric Talley argue, for example, that the liability rule price does not have to be set exactly right because parties will bargain around it. See Ian Ayres \& Eric Talley, Solomonic Bargaining: Dividing a Legal Entitlement to Facilitate Coasean Trade, 104 YALE L.J. 1027, 1036-39 (1995).

${ }^{326}$ See supra notes $255-56$ and accompanying text.

327 David, supra note 221, at 43. See also S.G. Winter, Patents in Complex Contexts, in Weil and Snapper, ed., supra note 15, at 41, 57 (noting that "[o]n the empirical side, there is plenty of evidence for the general proposition that industrial contexts are extremely diverse in ways relevant to intellectual property policy, and for the specific proposition that patents do not always, or even generally, play a key role"). 
Of course, we could view the biotechnology industry as sui generis and come up with a legislative scheme that would apply only to that particular industry. In the computer industry, for example, sui generis protection has been conferred on semiconductors. ${ }^{328}$ Some commentators have also urged Congress to create a sui generis type of protection for computer software. ${ }^{329}$ Indeed, within a sui generis regime, the central patentability requirement of nonobviousness could be clarified to address the CAFC's misunderstandings regarding DNA sequence information. The possibility of interest group influence in a legislative scheme of such specialized application would be quite significant, however. ${ }^{330}$ Moreover, even if a sui generis approach could be flexible enough to accommodate future research developments in the biotechnology industry (a large assumption), ${ }^{331}$ the administrative costs of developing and applying such an approach would be quite significant. Even worse, we would likely face similar costs elsewhere: a sui generis approach to biotechnology would raise the question of whether many other industries merited a similarly industry-specific approach.

Moreover, in areas such as biotechnology, where new technologies and tools are constantly being developed, the law inevitably lags significantly behind the state of the art. ${ }^{332}$ For example, even if a legal change that made basic research inventions such as ESTs or SNPs less likely to be patentable were implemented, new inventions to which the legal standard would have to be applied would arise frequently. With respect to any particular inven-

328

See, e.g., Semiconductor Chip Protection Act, Pub. L. No. 98-620, \$302, 98 Stat. 3335, 33473356 (1984) (codified as amended at 17 U.S.C. $\$ \S 901-914$ (1994)) (providing specific protection to semiconductor "mask works").

${ }^{329}$ See, eg., Samuelson et al., supra note 227, at 2312; Pamela Samuelson, Creating a New Kind of Intellectual Property: Applying the Lessons of the Chip Law to Computer Programs, 70 MNN. L. REV. 471 (1985).

${ }_{330}$ See, e.g., George Stigler, A Theory of Economic Regulation, 2 BELL J. ECON. \& MGMT. SCI. 3 (1971) (discussing the tendency of legislation to favor politically active interest groups over the politically inactive majority). Indeed, because of interest group influence, it is unlikely that any such legislation would diminish intellectual property rights. For example, the single provision in the current patent statute that specifically addresses the biotechnology industry expands patent rights. See 35 U.S.C. \& 103 (b)(1) (1994) (expanding patent rights on biotechnology processes). Similarly, the trend of new copyright legislation in the computer software and digital media industries has been toward increased property rights. See Cohen, supra note 15, at 534-36.

${ }^{331}$ Notably, in the case of the sui generis approach taken in the Semicondutor Chip Protection Act, technological changes, specifically the decreased possibility of copying afforded by new chip designs, have significantly diminished the relevance of the Act. See Oddi, supra note 1, at 450-51. Cf. Lawrence Lessig, The Path of Cyberlaw, 104 YALE L.J. 1743 (1995) (arguing that legal regulation of cyberspace should proceed slowly because, given rapid technological change, lawmakers are likely to get such regulation wrong).

332 Many commentators have written about the confusion created by the uncertain application of patent law principles to the new technologies of biotechnology. See, e.g., Dan L. Burk, Biotechnology and Patent Law: Fitting Innovation to the Procrustean Bed, 17 RUTGERS COMPUTER \& TECH. L.J. 1 (1991); Phillip B. C. Jones, Patentability of the Products and Processes of Biotechnology, 73 J. PAT. \& TRADEMARK OFF. SOC'Y 372 (1991); Brad Sherman, Patent Law in a Time of Change: NonObviousness and Biotechnology, 10 OXFORD J. LEGAL STUD. 278 (1990). 
tion, it might take many years for the courts to make a final determination that the invention was not patentable. ${ }^{333}$ In the meantime, the work of those scientists who wished to use that invention might be chilled by the possibility that they would, in the future, be found liable for patent infringement. ${ }^{334}$

Finally, the availability of trade secrecy protection casts doubt on the proposition that relying solely on changes in the patent law will produce a sufficiently robust public domain. Private firms that cannot patent basic research will, in all probability, still exert property rights in such research through the mechanism of trade secrecy. Although trade secrecy provides weaker protection than patent rights in that it does not protect against independent invention or reverse engineering, it still impedes the free flow of information. In order for basic research truly to be in the public domain, it must be performed by entities that refrain from claiming any significant property rights in such research.

\section{Using Law and Norms Synergistically}

Thus far, I have discussed the multiple problems associated with relying upon strictly legal change to produce the appropriate balance between the public domain and property rights. In this section, I argue that the alternative of using legal change in a manner that reinforces efficient research norms would be a superior mechanism for balancing privatization and the public domain. I first analyze why the current research norms of mainstream universities are likely to be efficient. I then discuss ways in which law could reinforce and reflect these efficient norms.

As discussed in Part $\Pi$, research universities have developed informal policies that attempt to preserve certain elements of traditional research norms while incorporating some of the development-promoting aspects of property rights. Specifically, university policies privatize discoveries that are likely to have specific commercial uses while leaving in the public domain other discoveries (e.g., ESTs and SNPs) that may have a variety of future research uses, may be necessary for the development of many different commercial products, or may be difficult to utilize effectively without access to other discoveries. ${ }^{335}$ Where a discovery has a small number of clearly identified research and/or commercial uses, the creativity costs of assigning property rights are likely to be low. Similarly, the transaction

\footnotetext{
333 To cite perhaps the most notorious example, the issue of EST patentability is still with us, years after it was raised by the Craig Venter filing.

334 Indeed, even those who argue that uncertainty in patent law may be efficient emphasize that such efficiency arises only when uncertainty holds out the possibility that a valid patent will not be enforced. In that situation, uncertainty limits the patentees' market power and ability to charge a supracompetitive price. By contrast, uncertainty is not efficient when it holds out the possibility than an invalid patent will be enforced. See generally Ian Ayres \& Paul Klemperer, Limiting Patentees'Market Power Without Reducing Innovation Incentives: The Perverse Benefits of Uncertainty and Non-Injunctive Remedies, 97 MICH. L. REv. 985 (1999). Only the latter type of uncertainty is at issue here.

335 See supra notes $193-99$ and accompanying text.
} 
costs of licensing the discovery for development are likely to be low, particularly if developing the discovery does not require securing licenses on other patented material. By contrast, where a discovery has a variety of potential research and/or commercial uses, and cannot be developed without access to additional patented material, the creativity and transaction costs of assigning property rights are likely to be high. Thus, where transaction and creativity costs are low, university policies encourage privatization; where such costs are high, they discourage privatization. As a consequence, these policies appear to leave in the public domain that range of invention that could most effectively be utilized through open access, while privatizing that range of invention that could most effectively be utilized if there were a single rightsholder.

The fact that university research norms are efficient is not a mere coincidence. Rather, various structural features of university research make it likely that research norms will be efficient. For example, scholars have argued that efficient norms will evolve (and endure) in contexts where the parties involved have repeated interactions over the long term and can readily observe each other's behavior. ${ }^{336}$ In the case of research norms, the academic researchers and institutions for whom the norms hold sway do in fact interact repeatedly over the long term: the Association of University Technology Managers, which was involved in the development of the UBMTA, is one permanent product of this interaction.

Law-and-norms theorists have also noted that efficient norms are likely to emerge where the relevant parties have similar values and interests. ${ }^{337}$ Admittedly, the values and interests of researchers and institutions are more heterogenous now than in the days before private sector involvement in the licensing and funding of university research. Nonetheless, many major research universities share a basic commitment to open exchange, which they justify by appealing to traditional academic and research values favoring the free flow of information.

Efficient norms also tend to develop where the parties have access to relevant, up-to-date information. ${ }^{338}$ In the case of biotechnology research, the university researchers and technology licensing offices that develop patent policies most likely have access to information that is at least as good as that enjoyed by courts or by lawmakers. Indeed, because university researchers actually create the inventions at issue, they are more likely than courts or lawmakers to know whether a particular invention will have myriad possible uses-and therefore whether, on account of transaction and creativity costs, it should be left in the public domain. ${ }^{339}$

\footnotetext{
${ }^{336}$ See supra text accompanying note 41.

337 See supra notes $42-45$ and accompanying text.

338 See supra note 46 and accompanying text.

339 It bears mention, however, that one type of govemment actor-the administrative agency that is funding the research -often does have access to up-to-date scientific and technical information. In the
} 
Moreover, in contrast to case law or legislative change, research norms have the potential to respond relatively quickly to new technologies. ${ }^{340}$ Consider the example of SNPs. Major research universities have, in relatively short order, agreed to a presumption against the patenting of SNPs. Moreover, if norms that militate against patenting SNPs result in a large public database of SNPs, researchers will be able to use these SNPs freely, secure in the knowledge that because the SNP information is publicly available, it probably will not be patentable. ${ }^{341}$ By contrast, it might take years for the courts to interpret how a legal change that made basic research less likely to be patentable would apply to SNPs. ${ }^{342}$

Moreover, a norm response could be more precise than a legal response. In contrast to a legal approach that tried to use some change in generally applicable patent law doctrine to respond to the particular problems posed by SNP patenting (or other patenting in biotechnology area), a research norm against patenting SNPs (or other basic biotechnology inventions) could respond quite precisely to the problem. Unlike a more general change in legal doctrine, a norm-based approach intended to address problems posed by the patenting of certain basic research would not have unintended spillover effects into other research.

One basis for questioning the efficiency of current research norms is the problem of negative externalities. As a general matter, because group norms may produce externalities that affect individuals outside the group, norms that are efficient for the group are not necessarily globally efficient. $^{343}$ Similarly, research norms that are efficient for academic institu-

specific context of molecular biology research, the National Institutes of Health (NIH) does, by virtue of its own ongoing programs of intramural research and its intimate contact with the university scientific community, have good access to relevant scientific and technical knowledge. As a consequence, the NIH can and should take the lead in formulating legal changes that reinforce efficient norms. For further discussion of the NIH's role, see infra notes 345-52 and accompanying text.

340 Cf. David R. Johnson \& David Post, Law and Borders-The Rise of Law in Cyberspace, 48 STAN. L. REV. 1367, 1387-88 (1996) (making a broad argument in favor of using decentralized norms rather than state regulation in the rapidly changing world of cyberspace). One does not have to go as far as Johnson and Post to believe that decentralization in the form of norms can be useful in addressing rapidly changing technologies. For example, the First Annual Report of the U.S. Govemment's Working Group on Electronic Commerce notes that although some government regulation of electronic commerce will be necessary, standards and norms developed by the private sector should have a prominent role. See U.S. Government Working Group on Electronic Commerce, First Annual Report, at 7, 20 (on file with author) (noting that technical standards should be set by voluntary private organizations, not by govemments). See also id. at 8 ("Self-regulation in the digital age will require the private sector to engage in much greater collective action to set and enforce rules than was characteristic of the Industrial Age.").

341 The patent statute prescribes that an invention cannot be patented if it was described in a printed publication, or known or used by others, before its invention by the patent applicant. 35 U.S.C. \& 102(a) (1994). The patent law also prevents patenting an invention that was used or sold, or described in printed publication, more than one year prior to the date of the patent application. 35 U.S.C. § 102(b).

342 In the case of ESTs, the issue of patentability is still with us, years after the question was originally raised.

343 See supra text accompanying note 47. 
tions and/or researchers may not necessarily be globally efficient. ${ }^{344}$ For example, given the incentives created by Bayh-Dole, a university may have a financial motivation to seek as many low-cost, upstream patents as possible. With a large upstream patent portfolio, the university could then maximize revenue by securing lucrative exclusive licensing contracts or, in the absence of such contracts, filing infringement suits. Indeed, those private companies that have chosen to file patents on their upstream research appear to have adopted this approach as their business plan. Although such an approach might be desirable for the university, it would be inefficient as a global matter. However, there is little evidence of such norm violation by universities. Rather than engaging in strategic behavior to maximize revenue, universities are focusing their patenting efforts on inventions that are likely to have specific commercial uses. A commitment to traditional research values appears to have constrained purely strategic behavior.

Of course, the fact that most universities are not currently seeking to establish and enforce property rights to the full extent allowed by the BayhDole Act and by patent case law does not necessarily mean that, in the future, norms may not shift towards a greater emphasis on property rights. In order for such norm shift to occur, however, a critical mass of norm violators must emerge. The critical mass is not likely to emerge so long as the law acts to reinforce private sanctions against norm violators. In what follows, I address various mechanisms by which law could impede norm violation, address behavior by private industry that undermines the efficacy of norms, and affirmatively support adherence to norms. I begin with mechanisms for positive reinforcement of norms.

Government policy could act to reinforce these research norms in a number of ways. First, in those areas of basic research where researchers and research universities are expressing reservations about patenting, the funding government agency might explicitly discourage the pursuit of patents. Francis Collins, the Director of the National Human Genome Research Institute (NHGRI) at the $\mathrm{NIH}$, has already made some creative efforts in this direction. In April 1996, NHGRI announced a set of rules that require recipients of large-scale human genome sequencing grants to release new DNA information as rapidly as possible and to refrain from patenting. As the NHGRI announcement of the rules pointed out, they are based in part on a February 1996 resolution passed by a private meeting of top genome researchers. In that resolution, the researchers unequivocally stated that expeditious research and development was dependent on largescale human genomic information being freely available. ${ }^{345}$

\footnotetext{
344 Indeed, the global inefficiency of traditional research norms was one of the reasons that the govemment felt compelled to change norms by passing the Bayh-Dole Act and other pro-patent legislation. See supra note 103 and accompanying text.

${ }^{345}$ See supra text accompanying note 200 (discussing February 1996 resolution).
} 
Under the Bayh-Dole Act, the NIH has only limited legal authority to enforce a ban on patent applications. The Act provides that "exceptional circumstances" must exist before an agency can determine that restriction or elimination of a university's right to seek patents on an invention serves the Act's goals of development and commercialization. ${ }^{346}$ Moreover, the determination of "exceptional circumstances" is subject to an administrative appeals procedure. ${ }^{34} 7$ Thus, in order to enforce the ban against a recalcitrant university contractor, the agency would have to prove that these exceptional circumstances existed. But the NIH is hoping that hortatory language designed to appeal to already-existing (if threatened) research norms will obviate the need for protracted administrative proceedings. ${ }^{348}$ Francis Collins has also launched a similar effort to have the NIH and other federal research agencies fund research on SNPs on the condition that the results of that research are to be. placed in public databases without restrictions on their use. ${ }^{349}$ A recent NHGRI/NIH request for applications to fund research on SNPs requires applicants to submit their plans for public release of SNP data. The RFA specifies that the adequacy of the applicants' data sharing plan will "be considered by the NIH staff as one of the criteria for award.",350

The government can also reinforce research norms through the example of its own behavior. In this regard, the NIH's decision to refrain from filing patent applications on the majority of research tools that it has developed through its intramural research program ${ }^{351}$ is a salutary one. Similarly,

34635 U.S.C. $\$ 202$ (a)(ii) (1994) (noting that a funding agreement may refuse to allow a contractor to retain title ownership "in exceptional circumstances when it is determined by the agency that restriction or elimination of the right to retain title to any subject invention will better promote the policy and objectives of [Bayh-Dole].").

34735 U.S.C. $\$ 203(2)$ (1994).

348 NHGRI is also requiring grantees to notify NIH of discoveries that may be patented. This will allow NHGRI to "'monitor grantee activity in this area to leam whether or not attempts are being made to patent large blocks of primary human genomic DNA sequence." Marshall, supra note 200, at 477.

349 See Eliot Marshall, 'Playing Chicken' over Gene Markers, 278 SCIENCE 2046 (1997). Collins and Aravinda Chakravarti, a geneticist at Case Western Reserve University who is the most prominent academic champion of a public SNP database, warn that if the effort does not succeed, SNP information might then be subject to "'a tangled web of restrictive intellectual property attachments . . . inhibiting many researchers from using these powerful tools."' Id. at 2046.

${ }^{350}$ See Request for Applications, Methods for Discovering and Scoring Single Nucleotide Polymorphisms, at 7 (visited Sept. 14, 1999) <http:/www.nhgri.nih.gov/grant_info/funding/RFA/rfa-hg-98$002 . \mathrm{html}>$. More generally, recent policy guidelines promulgated by the NIH attempt to limit the scope of the patenting under the Bayh-Dole Act. They state that "the use of patents and exclusive licenses is not the only, nor in some cases the most appropriate, means of implementing the [Bayh-Dole] Act. Where the subject invention is useful primarily as a research tool, inappropriate licensing practices are likely to thwart rather than promote utilization, commercialization and public availability of the invention.... Utilization, commercialization, and public availability of technologies that are useful primarily as research tools rarely require patent protection ...." NIH, Principles for Recipient of NIH Research Grants and Contracts on Obtaining and Disseminating Biomedical Research Resources, at 3 (visited Sept. 14, 1999) <http://www.nih.gov/od/ott/RTguide.htm> [hereinafter NIH Principles].

351 See NIH Working Group Report, supra note 190, app. D. In addition, the NIH has decided to maintain a non-exclusive licensing policy with respect to research tools on which it has patents. Under 
the NIH's refusal to enter into MTAs that require it to assign future intellectual property rights to the provider ${ }^{352}$ serves as an important model for universities.

It might be argued that reliance on these research norms-even as reinforced by the legal and policy efforts outlined above-is insufficient to address the problem of excess patenting. After all, a substantial portion of basic research-11.7\% of academic research in the life sciences, according to one recent estimate ${ }^{353}$-is now funded by the private sector. Industry actors, who are not constrained by norms, will simply refuse to fund basic research in universities unless they can obtain exclusive rights on it. Alternatively, industry actors may do the basic research, and seek patents on it, before information can be put in the public domain. For example, Human Genome Sciences (HGS) and Incyte, Inc. have already sequenced hundreds of thousands of ESTs and have filed patent applications on them.

Moreover, industry actors might not even represent the most significant problem. Even within the academic sector, we could have a significant number of norm violators. For example, in the context of academic sharing of research tools, we have some evidence of norm violation. While the terms of the UMBTA require that the more than one hundred university signatories transfer biological materials freely to other academic institutions, researchers have complained that a significant number of universities are not following the terms of the UMBTA. There is evidence to sugest that MTAs from universities that export research tools to other universities have included clauses requiring, inter alia, assignment of intellectual property rights in research results that arise from use of the tools, publication delays pending a determination of intellectual property rights, and prohibitions of transfer of the tools to other research institutions. ${ }^{354}$

Fortunately, the government has various means at its disposal to address the behavior of private firms and academic norm violators. Dealing with patenting by industry actors should be relatively straightforward. In those areas of basic research where the public domain is particularly important, we could have federal funding targeted at generating the research and releasing it publicly. Public release of particular research findings might preempt patent applications not only on those specific findings but also in that research area as a whole. For example, in the context of largescale human genome sequencing, the public release by academic researchers of "raw" genome data may have been responsible for the decision of some private companies not to claim intellectual property rights in any such

the Bayh-Dole and Stevenson-Wydler Acts, federal agencies have authority to apply for (or to refrain from applying for) patents on their intramural research. See supra note 118 and accompanying text.

352 NIH Working Group Report, supra note 190, app. D. The actions of the NIH are particularly important to the university scientific community because NIH leaders come from, and are likely to retum to, this community.

353 See Blumenthal et al., supra note 185 , at 369.

354 NIH Working Group Report, supra note 190, at 10. 
data. ${ }^{355}$ Public funding should occur early in the research process, so that the aggressive patenting policies of private firms do not have a preemptive effect (as, arguably, private firm policies have had in the context of ESTs). Notably, the amount of public funding necessary should be quite small. As discussed above, ${ }^{356}$ the capital costs of inventing basic research are relatively low, and the invention norm significantly reduces the cost of any labor subsidy that may be needed. ${ }^{357}$ Moreover, at least in some cases, public funding might be supplemented by private funding from industry actors, such as pharmaceutical companies, that are interested in keeping upstream research in the public domain. For example, in the case of the non-profit SNP Consortium that has been formed to put information about SNPs into the public domain, ${ }^{358}$ about half of the funding is private; the Wellcome Trust, a London-based foundation that is working closely with the National Human Genome Research Project, will provide the other half. ${ }^{359}$

As for problems caused by norm violators, there is a substantial amount that agencies such as the NIH can do to rein in such violators. For example, in response to concerns that some universities are using MTAs that violate the letter and spirit of the UMBTA, the NIH has issued for public comment a set of proposed "Principles and Guidelines for Recipients of NIH Research Grants and Contracts on Obtaining and Disseminating Biomedical Research Results." ${ }^{, 360}$ The proposed principles in this document urge all NIH grant recipients "to streamline the process of transferring their own research tools freely to other academic research institutions" by using either no formal agreement or some form of the UMBTA. ${ }^{361}$ Although the broad language of the principles may be difficult to enforce as a legal mat$\operatorname{ter}^{362}$ the NIH could certainly enforce the specific "guidelines" that partially implement the broad language. For example, the guideline that unpatented materials developed with $\mathrm{NIH}$ funds must be made available to

355 See supra text accompanying note 207.

356 See supra Part III.A.

357 To be sure, the idea of providing even small amounts of public funding for research that the private sector is willing to do may appear counterintuitive. The traditional rationale for public funding of basic research has been that the private sector will be overly concemed about the long-term commercial prospects of such research and will therefore underinvest in it. See Arrow, supra note 215. In the context of biotechnology, however, this traditional rationale needs to be expanded. This is because, in biotechnology, a basic infrastructure of freely available scientific knowledge is necessary for achieving invention and development. So long as private companies choose to assert property rights in their basic research (whether in the form of patent filings or trade secrecy), small amounts of targeted funding will be necessary to maintain that infrastructure.

358 See supra text accompanying notes 302-04.

359 See Wade, supra note 208.

360 See NIH Principles, supra note 350.

361 Id.at 3.

362 For example, with respect to patented materials, the Bayh-Dole Act limits the agency's power over a grant recipient to a requirement of licensing. 35 U.S.C. $\$ 203(1)$ (1994). Moreover, even this limited power can only be exercised if the agency make findings that the contractor has failed to commercialize the invention. The agency determination is also subject to an administrative appeals procedure. 
other NIH fund recipients ${ }^{363}$ is already well-accepted NIH policy. ${ }^{364}$ In addition, as the guidelines point out, the NIH could certainly use its authority under the Bayh-Dole Act to prohibit grantees in NIH funded projects from signing MTAs that require the assignment of title to the provider. ${ }^{365}$

To the extent that greater legal authority is needed to rein in norm violators, the Bayh-Dole Act could be amended so as to give the NIH authority to require compliance with the UMBTA in the context of all biological materials developed with NIH funds. More broadly, the Act could be amended to give the NIH (and other federal agencies) discretion to bar patent applications by all federal funding recipients in those areas where a significant percentage of the scientific research community was expressing skepticism about patents. For example, the requirement that "exceptional circumstances" be present in order for the agency to withhold patent rights could be changed to a requirement of "significant evidence that patenting does not further the goals of development and commercialization." The foundation of this "significant evidence" determination could, in turn, be the sentiment of the relevant research community. Amendments to the Bayh-Dole Act could also streamline the currently cumbersome process through which agencies can demand licensing of government-funded inventions on which universities own patents. ${ }^{366}$ Small changes in the patent statute (or in its implementation) might also be advisable. For example, in determining whether a particular invention meets the threshold of utility required for patentability, courts could take into account the approach taken by the academic research community on that invention.

In sum, there is substantial reason to believe that residual norms of academic scientific research create a public domain that embodies the appropriate balance between the various costs of the research and development process. As a consequence, government reinforcement of these norms may be an extremely valuable mechanism for achieving the invention and development goals of intellectual property law.

\section{CONCLUSION}

Legal rules and social norms are powerful and interdependent institutions for shaping behavior. Law-and-norms analysis represents a valuable tool for determining how these institutions should be deployed. Applying an efficiency-focused variant of law-and-norms analysis to basic research in molecular biology reveals that the federal government's past efforts to dis-

\footnotetext{
363 NIH Principles, supra note 350, at 4.

364 See NIH Working Group Report, supra note 190, app. D.

365 Id. at 7.

366 NIH Working Group Report, supra note 190, app. D (noting that, under current law, the right to demand licensing "might be of use on a case by case basis to improve access to particular research tools, but it is cumbersome mechanism that does not lend itself routine use .... Each particular case can be expected to be lengthy and uncertain").
} 
place information-sharing norms with intellectual property rights have failed to recognize those contexts in which invention and development goals are promoted more effectively through the public domain than through privatization.

Limiting the excessive incentives for privatization created by past government efforts poses an interesting challenge. Law alone is problematic for a variety of reasons: legal rules evolve too slowly to accommodate rapid technological change; legal rules of general application sweep more broadly than may be efficient; and legal actors are typically not, as an institutional matter, well qualified to gather and analyze the information relevant to determining whether, from the standpoint of achieving an optimal level of creation and development, a particular invention should be patented. By contrast, universities and university researchers do not need to formulate legal rules of general application. Rather, they can, in a relatively short period of time, formulate policies that respond precisely to new technologies. In addition, they are likely to have good access to the information relevant to determining whether a particular invention should be patented. As a consequence, it makes sense to rely not just on law but also on the norms that universities are creating and implementing.

This argument in favor of research norms in basic biotechnology research is hardly a call for private ordering over public regulation. To the contrary, reliance on norms to preserve a public domain in biotechnology will require significant government efforts to reinforce and protect these norms. These efforts, which should be undertaken primarily by agencies like the NIH that have a sophisticated understanding of the relevant research, will be necessary to ensure the persistence of norms against the corrosive effect of norm violators and industry actors who seek property rights simply in order to maximize revenue.

Properly understood and applied, law-and-norms analysis cautions against a mechanical reliance on either private ordering or public regulation. Rather than offering a set of a priori conclusions, it offers a set of tools for undertaking a pragmatic inquiry into the particulars of any given regulatory puzzle. In certain contexts, this pragmatic inquiry may indicate than any reliance on norms (whether those of the scientific community or any other community) is ill-advised. In other cases, it may yield no definite conclusion. In the context of basic research in biotechnology, however, the inquiry yields a clear affirmative prescription-concerted public and private action, centered around existing norms, to preserve the public domain. 